\title{
RESERVATÓRIO PAIVA CASTRO - MAIRIPORÃ - SP AVALIAÇÃO DA QUALIDADE DA ÁGUA SOBRE ALGUNS PARÂMETROS FÍSICOS QUÍMICOS E BIOLÓGICOS (1987/1998)
}

\section{LEANDRO LUIZ GIATTI}

Dissertação de Mestrado apresentada ao Departamento de Saúde Ambiental da Faculdade de Saúde Pública da Universidade de São Paulo para obtenção do Grau de Mestre.

Área de concentração:

Saúde Ambiental

Orientador: PROF. DR. ARISTIDES ALMEIDA ROCHA 


\section{AGRADECIMENTOS}

Agradeço aos meus pais a vida, a todos os ensinamentos e todo o apoio. Agradeço ao meu irmão Luciano por toda a ajuda.

Agradeço ao meu orientador, Professor Aristides Almeida Rocha, por disponibilizar seu conhecimento e experiência, sempre me atendendo com muita atenção e amizade.

Agradeço aos amigos do Departamento de Saúde Ambiental, especialmente à Solange por me ajudar constantemente nesse trabalho, também à Maria do Carmo à Silvana e ao Professor José Luis por escrever meu abstract.

Agradeço à todos os amigos da SABESP que disponibilizaram as informações necessárias para a elaboração desta dissertação, em especial à Cida, Edvaldo e Engenheiro Armando Flores da Divisão de Gestão da Qualidade da Produção e também ao Márcio e Sr. Emílio da Equipe de Proteção aos Mananciais da Elevatória Santa Inês.

Agradeço à todos amigos e familiares que estiveram comigo nessa realização, incentivando e reconhecendo o meu trabalho.

Tenho a consciência que esta foi uma realização conjunta, onde contei com a participação de pessoas especiais que me apoiaram de diversas formas. É muito bom poder contar com pessoas que ajudam de maneira despretensiosa, demonstrando a mais sincera amizade, pois sem elas esta conquista não seria possível.

Em certos momentos desse trabalho senti as coisas caminharem tão bem que tive a impressão, de que realmente, o universo conspira a nosso favor. Na verdade existe uma força superior por traz disso tudo e que muitas vezes se manifesta através da natureza e das pessoas amigas.

Agradeço à Deus a vida, as boas amizades e a oportunidade de aprender. 


\section{RESUMO}

O Sistema Cantareira é o mais importante manancial de abastecimento para a Região Metropolitana de São Paulo, sendo responsável por $58 \%$ das vazões ofertadas a 17,2 milhões de habitantes. É composto por 6 represas interligadas por um sistema de canais e túneis por derivações trazendo águas de outras bacias hidrográficas inclusive do Estado de Minas Gerais.

O reservatório Paiva Castro é o último corpo d'água do sistema de derivações e o mais próximo da metrópole. Situado em maior parte no município de Mairiporã, ao norte da Região Metropolitana, com grandes pressões de crescimento populacional e precariedade em saneamento básico, possui área urbanizada na bacia do referido reservatório, apresentando uma ameaça à qualidade da água deste importantíssimo sistema de abastecimento público.

O estudo da qualidade da água desse corpo d'água tornou-se possível graças à disponibilização de bancos de dados mantidos pela SABESP (Companhia de Saneamento Básico do Estado de São Paulo) e pela CETESB (Companhia de Tecnologia de Saneamento Ambiental do Estado de São Paulo), contendo dados registrados a partir de um trabalho de vigilância de diversos parâmetros relevantes ao processo de potabilização da água para abastecimento público.

Através da análise dos dados é possível verificar os baixos níveis de poluição registrados na água proveniente das represas à montante do reservatório Paiva Castro, permitindo inferir sobre os impactos sofridos pelo sistema nas áreas de influência do município de Mairiporã. 


\begin{abstract}
The Cantareira system is the most important water supply reservoir to the Metropolitan Area of São Paulo, being responsible for 57\% of the total amount of water offered to 17.2 million people. It is formed by 6 reservoirs inter-connected through a system of tunnels and channels, bringing water from other basins, including some located in the state of Minas Gerais.

Paiva Castro reservoir is the last water body in the system and the one nearest São Paulo. Most of its surface is in Mairiporã, in the northern part of the Metropolitan Area, with a heavy population growth and very poor sanitary conditions. Furthermore, the urban area within the reservoir's basin threatens the water quality of this important water supply system.

The study of its water quality was possible because of the availability of data banks from SABESP (Companhia de Saneamento Básico do Estado de São Paulo) and CETESB (Companhia de Tecnologia de Saneamento Ambiental), containing information collected during a survey to screen parameters that are important in the treatment of drinking water.

The analysis of these numbers shows low levels of pollution in waters coming from the reservoirs located before Paiva Castro, indicating that the most important environmental impacts are due to the activities in the city of Mairiporã.
\end{abstract}




\section{ÍNDICE}

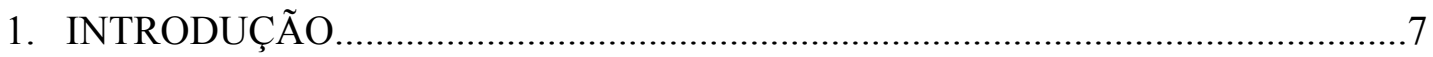

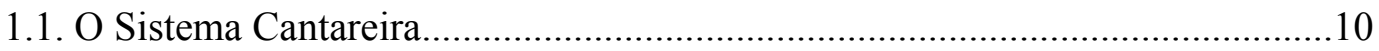

1.2. O Município de Mairiporã e o Reservatório Paiva Castro...................................15

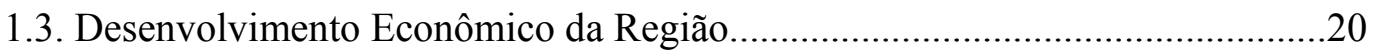

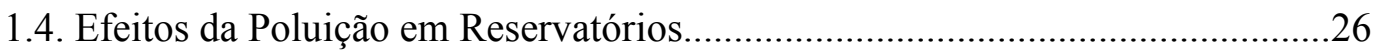

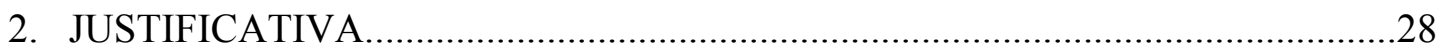

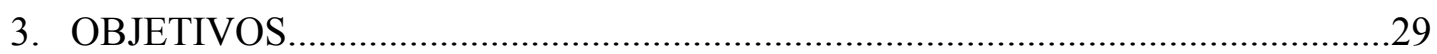

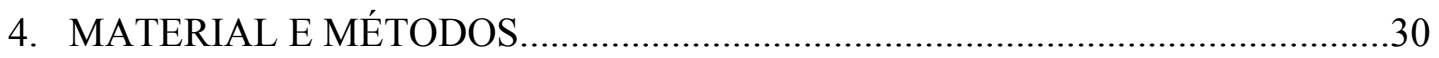

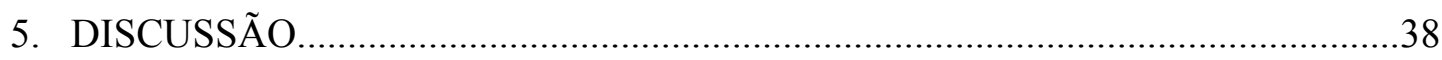

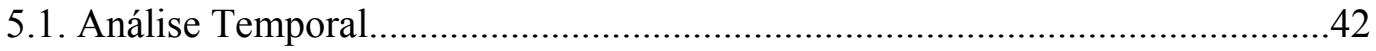

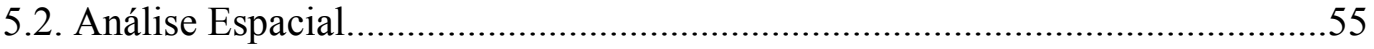

5.3. Florações de Algas no Reservatório Paiva Castro.................................................64

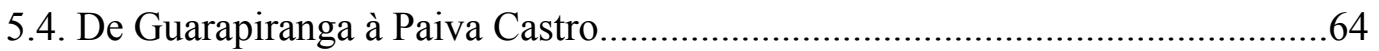

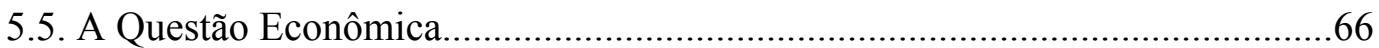

5.6. A Contaminação do Manancial como Risco à Saúde Pública.............................70

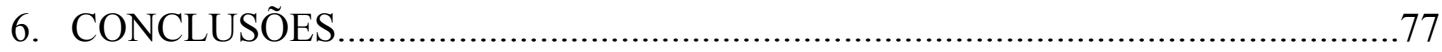

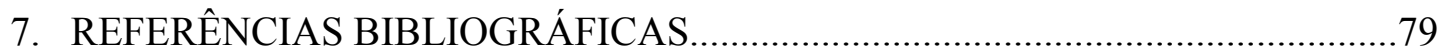

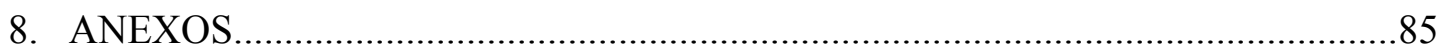




\section{ÍNDICE DE ILUSTRAÇÕES}

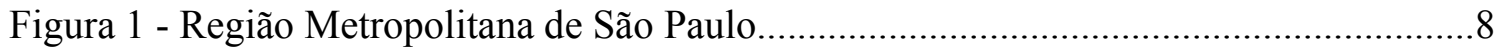

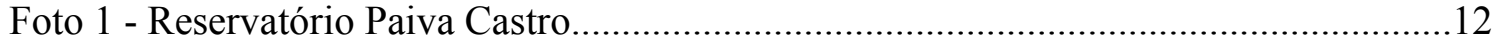

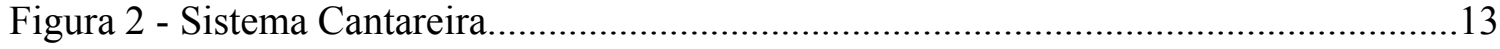

Figura 3 - Perfil Hidráulico do Sistema Cantareira............................................................... 14

Foto 2 - Área urbana de Mairiporã e a "cauda" do Reservatório Paiva Castro......................16

Foto 3 - Estação de Tratamento de Esgotos de Mairiporã.....................................................19

Foto 4 - Captação de Água da SABESP de Mairiporã..........................................................19

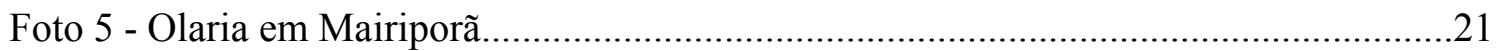

Foto 6 - Obra de duplicação da Rodovia Fernão Dias........................................................22

Foto 7 - Saída do Túnel 5, deságüe na bacia do Rio Juqueri................................................43

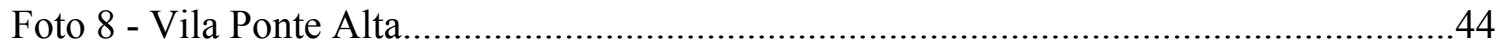

Foto 9 - Loteamento irregular na Vila Ponte Alta................................................................4

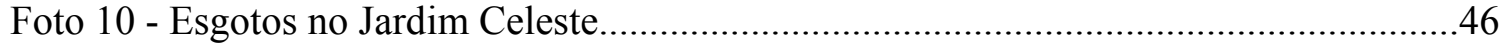

Foto 11 - Ribeirão Itaim e esgotos do Parque Náutico..........................................................

Foto 12 - Bairros da margem direita do reservatório...........................................................49

Foto 13 - Jardim Capri na bacia do Ribeirão Barreiro............................................................

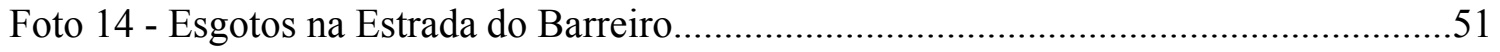

Imagem de Satélite do Reservatório Paiva Castro e pontos de coleta SABESP..........ANEXO 


\section{INTRODUÇÃO}

As questões relativas ao abastecimento de água das populações vem sendo registradas ao longo da história da humanidade devido a importância fundamental para a sobrevivência das aglomerações humanas.

Nesse sentido é de se lembrar que as civilizações do antigo Egito e da China, assim como da Índia e da Mesopotâmia, ficaram conhecidas como "civilizações hidráulicas”. A ascensão e subseqüente queda dessas formidáveis culturas estão intimamente relacionadas ao uso e abuso da água (DREW, 1985 apud RUTKOWSKI, 1999).

Já no primeiro século da Era Cristã um importante registro indica a seriedade com que se deve tratar o abastecimento de água. WIENDL (1983) traduzindo a obra de Sextus Julius Frontinus - Das águas da cidade de Roma, 97 à 104 d.C. - destaca que o grande valor daquele empreendimento reside no fato de que, naquela época, Roma contando com mais de 1 milhão de habitantes, dispunha de um sistema de abastecimento de água por aquedutos comparável, sob vários aspectos, aos de nossas modernas cidades. Ressalta-se ainda que a administração de Frontinus encontrou os mais variados tipos de problemas, alguns dos quais permanecendo na pauta das preocupações dos encarregados de operações de sistemas públicos até o presente.

Mesmo na atualidade a problemática referente aos recursos hídricos e abastecimento público constitui uma questão relevante, principalmente na Grande São Paulo por se tratar do maior conglomerado urbano da América do Sul, que além de precisar suprir as necessidades de água para 17,2 milhões de habitantes dispersos em 39 municípios (figura 1), onde cerca de $10 \%$ da população do país ocupa menos de 1 milésimo do território nacional (EMPLASA - Empresa Metropolitana de Planejamento da Grande São Paulo SA, 2000), também precisa superar as dificuldades geográficas, como fatores limitantes à quantidade de água disponível na região.

A Região Metropolitana de São Paulo, ao contrário da grande maioria das metrópoles, que se desenvolveram em faixas litorâneas ou às margens de caudalosos rios, está próxima a regiões de cabeceiras de cursos d'água (Alto Tietê, Alto Juquiá, Alto 
Piracicaba e Paraíba Superior). Situada no Planalto Atlântico, com altitudes superiores a 700 metros, próxima ao litoral, porém nas vertentes internas da Serra do Mar, onde nasce o rio Tietê, afluente do Paraná e um dos formadores do Prata, a aglomeração paulistana teve origem e desenvolveu-se dentro da Bacia do Alto Tietê, que compreende $70 \%$ da área da Grande São Paulo, estando, portanto, como enfatizado, em cabeceiras, o que pode explicar a escassez relativa de recursos hídricos (NUCCI e col. 1976).

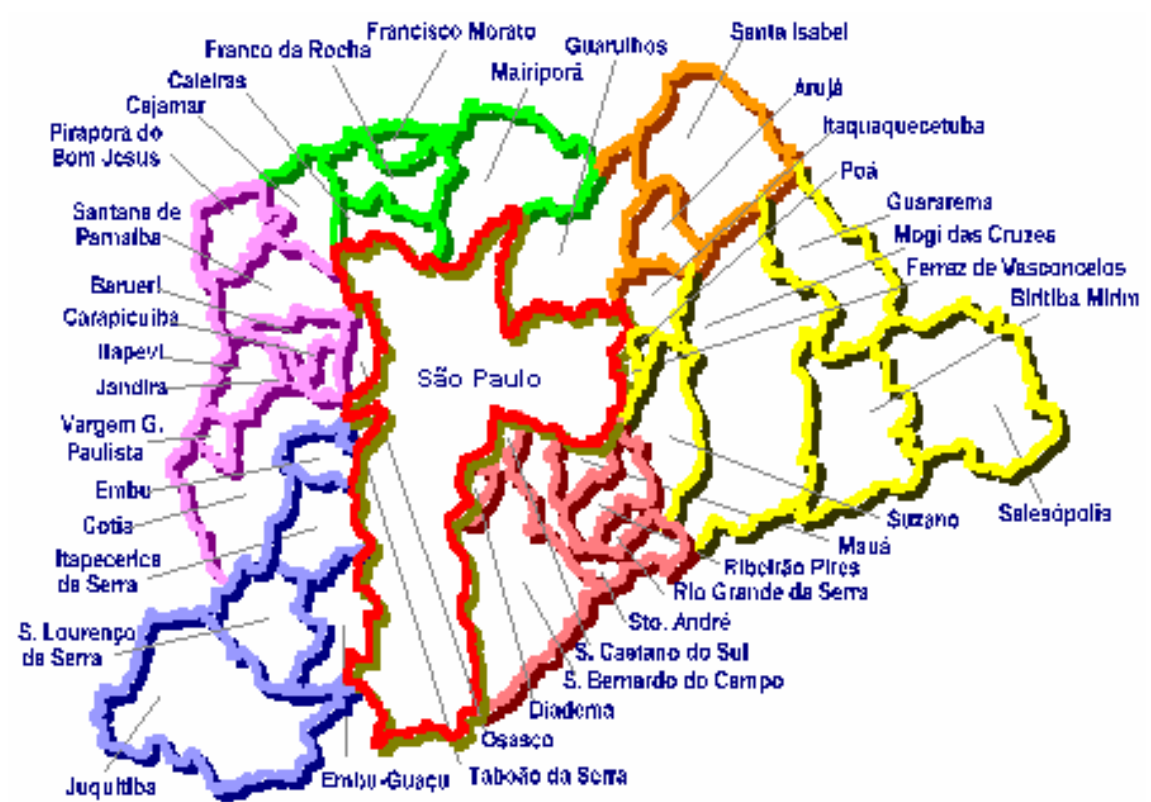

Figura 1: Região Metropolitana de São Paulo - Fonte: Emplasa, 2000.

Nas fases iniciais de urbanização da cidade de São Paulo, o abastecimento de água deu-se predominantemente por atendimentos de pequeno porte, merecendo destaque o antigo sistema de pequenas represas na Serra da Cantareira, situadas ao norte da cidade (SABESP - Companhia de Saneamento Básico do Estado de São Paulo, 1989).

No tempo dos bandeirantes, nos séculos XVI e XVII, os tropeiros que vinham de Minas Gerais à São Paulo paravam nesta serra afim de reabastecer seus cântaros (como eram denominados os jarros de armazenar água), os quais eram guardados em prateleiras chamadas cantareiras, daí a origem do nome em virtude da abundância de fontes de água de boa qualidade no local (FOREST, 2000). 
Posteriormente, a Serra da Cantareira, após ser escolhida e ter sido iniciada a utilização de suas águas, foi alvo, entre 1894 e 1911, da desapropriação de vinte fazendas e outras propriedades rurais, fato que possibilitou a recuperação da floresta tornando difícil perceber a diferença entre a zona reflorestada e a mata virgem primária. Foram assim restabelecidos os antigos habitats e nichos para espécies da fauna local. Por essas razões, atualmente, a Serra e o Parque Estadual da Cantareira ocupam uma área de 3200 alqueires constituindo a maior floresta contida numa área metropolitana no planeta, sendo administrada pelo Instituto Florestal (SÃO PAULO - ESTADO, 1993).

Fatos históricos da utilização dos recursos hídricos provenientes da região da Serra da Cantareira são relatados por ROCHA (1997), que também apresenta citações do historiador Afonso A. de Freitas, do Instituto Histórico e Geográfico de São Paulo, descrevendo em seu Dicionário Histórico, Topográfico, Etnográfico Ilustrado, de 1929:

"O abastecimento de água à população paulistana foi sempre, desde os primórdios da povoação, deficiente e precário, não pela escassez do óxido vital, que as encostas do planalto em que se elevava a incipiente cidadezinha de São Paulo do Campo, foram sempre ricas de nascentes de água cristalina, porém pela dificuldade de sua captação e transporte... ...já em 1863 o Governo da Província comissionaria o Engenheiro James Brunless, de Londres, para estudar um plano geral de abastecimento e também de esgotos que colocasse a Capital definitivamente a salvo da multissecular falta de água e das ameaças de epidemia que a falta de higiene fazia permanente pairar sobre a população citadina... ...e em janeiro de 1864 apresenta, em relatório oferecido ao governo da Província, o resultado dos seus estudos opinando pela utilização das águas da Serra da Cantareira no dessedentamento do paulistano."

Ocorre então, em 25 de junho de 1877 a organização da Companhia Cantareira de Água e Esgotos, empresa particular com o propósito de explorar os serviços de águas e esgotos da Capital, levando avante um empreendimento acabado em 1881, o qual constituía-se do Reservatório da Consolação, localizado em terrenos da antiga Chácara 
do Capão, passando a receber águas aduzidas dos córregos Toninho, Iguatemi e Barro Branco.

Fato curioso ocorreu quando haviam 4.155 residências ligadas pela nova rede de abastecimento, a população habituada a fazer uso da água de chafariz, foi relutante em passar a utilizar as águas vindas da zona norte por canos subterrâneos de 30 centímetros de diâmetro e 14,5 quilômetros de extensão. Tal mudança só foi acatada diante do fechamento dos chafarizes e intervenção da Força Pública (FOREST, 2000).

Em 1892 devido ao crescimento populacional e não atendimento da demanda por água a Companhia Cantareira entra em crise e é criada a Repartição de Águas e Esgotos (RAE) que sob sua administração pública inaugura, em 1893, o Sistema de Tratamento do Ribeirão Guaraú também na Serra da Cantareira (ROCHA, 1997).

No entanto, o crescimento da metrópole acabou por formar áreas com elevado grau de deficiência de abastecimento, sobretudo na Zona Norte de São Paulo, uma vez que os novos mananciais à disposição situavam-se ao Sul e a Leste da Cidade. Com vistas a se atender às crescentes pressões daí advindas, inicia-se em 1965 o aproveitamento daquele que viria a constituir o novo Sistema Cantareira, mediante o início das obras da captação do rio Juquerí, localizado ao Norte do município de São Paulo, no município de Mairiporã, transpondo então, o maciço da Serra da Cantareira. Os esforços da implantação deste sistema estenderam-se ao longo de mais de uma década, sendo que a tecnologia empregada constituiu um marco na história do saneamento no Brasil (SABESP, 1989).

\subsection{O SISTEMA CANTAREIRA}

A implantação do sistema aconteceu em duas etapas, sendo a primeira referente ao aproveitamento dos rios Juquerí, Atibainha e Cachoeira dispondo uma vazão de $11 \mathrm{~m}^{3} / \mathrm{s}$ que entrou em operação em 1974, a segunda etapa iniciada em 1976 foi relativa ao aproveitamento dos rios Jaguarí e Jacareí e entrou em operação em 1981, disponibilizando o sistema para sua configuração final de $33 \mathrm{~m}^{3} / \mathrm{s}$. A implantação do 
sistema apresenta um imensurável efeito sobre a sustentação do processo de desenvolvimento da Região Metropolitana, sendo que em 1984 a população atendida pelo sistema integrado saltou da cifra de $60 \%$ para $95 \%$. O Sistema Cantareira é o principal manancial abastecedor da Região Metropolitana, sendo responsável pelo fornecimento de $58 \%$ das vazões oferecidas.

O Sistema Cantareira é composto pela estação de tratamento de água do Guaraú, estação elevatória Santa Inês e pelos reservatórios de Águas Claras, Paiva Castro, Atibainha, Cachoeira e Jaguarí-Jacareí. Embora haja contribuição de águas vindas da região sul do Estado de Minas Gerais os reservatórios que integram o sistema situa-se no Estado de São Paulo (figura 2). Todos os reservatórios são interligados entre si através de derivações por gravidade em canais e túneis e pela estação elevatória de Santa Inês, a qual transpõe as águas ao longo da Serra da Cantareira em direção ao reservatório de Águas Claras (figura 3) situado já na vertente da bacia do Alto Tietê, a montante da ETA do Guaraú que por sua vez está a montante da RMSP a uma altitude de $840 \mathrm{~m}$ do nível do mar de onde suas águas são distribuídas por gravidade (SABESP, 1989).

Pelo fato das principais nascentes das bacias hidrográficas formadoras dos reservatórios Jaguarí/Jacareí e Cachoeira serem provenientes da região sul do estado de Minas Gerais, e ainda acrescido o reservatório Atibainha com áreas pertencentes à bacia hidrográfica do Rio Piracicaba, sendo estas revertidas à bacia do Alto Tietê, são criados conflitos no tocante a gestão destes recursos hídricos, uma vez que na Bacia do Piracicaba/Capivari e Jundiaí (região de Campinas com cerca de 4,0 milhões de habitantes), há problemas nas captações de água das cidades, dada a má qualidade dos recursos hídricos onde apenas $4 \%$ dos esgotos gerados são tratados. Diante da proposição de que o Sistema Cantareira seja permanentemente destinado ao abastecimento público da bacia do Alto Tietê (Região Metropolitana de São Paulo), há uma recomendação para que a bacia do Piracicaba seja ressarcida monetariamente dessa reversão (HIDROPLAN, 1995).

Possuindo grande parte de suas nascentes revertidas, a bacia do rio Piracicaba encontra-se em condição de estresse, deixando a segunda maior região de crescimento econômico do estado em uma situação de risco (RUTKOWSKI, 1999). 
Voltando ao Sistema Cantareira, é importante verificar que o reservatório Paiva Castro (foto 1) caracteriza-se como o último do sistema de derivações por gravidade, sendo formado de um barramento no rio Juquerí no município de Franco da Rocha (SP) e contando com a recepção da água proveniente dos demais reservatórios. Ocorre que o reservatório Paiva Castro, contido principalmente no município de Mairiporã, situa-se à jusante da área urbanizada do município.

Este reservatório possui uma área de drenagem de $314 \mathrm{Km}^{2}$ e contribui com $4,4 \mathrm{~m}^{3} / \mathrm{s}$ da vazão total de $33 \mathrm{~m}^{3} / \mathrm{s}$ do Sistema Cantareira (SABESP, 1989).

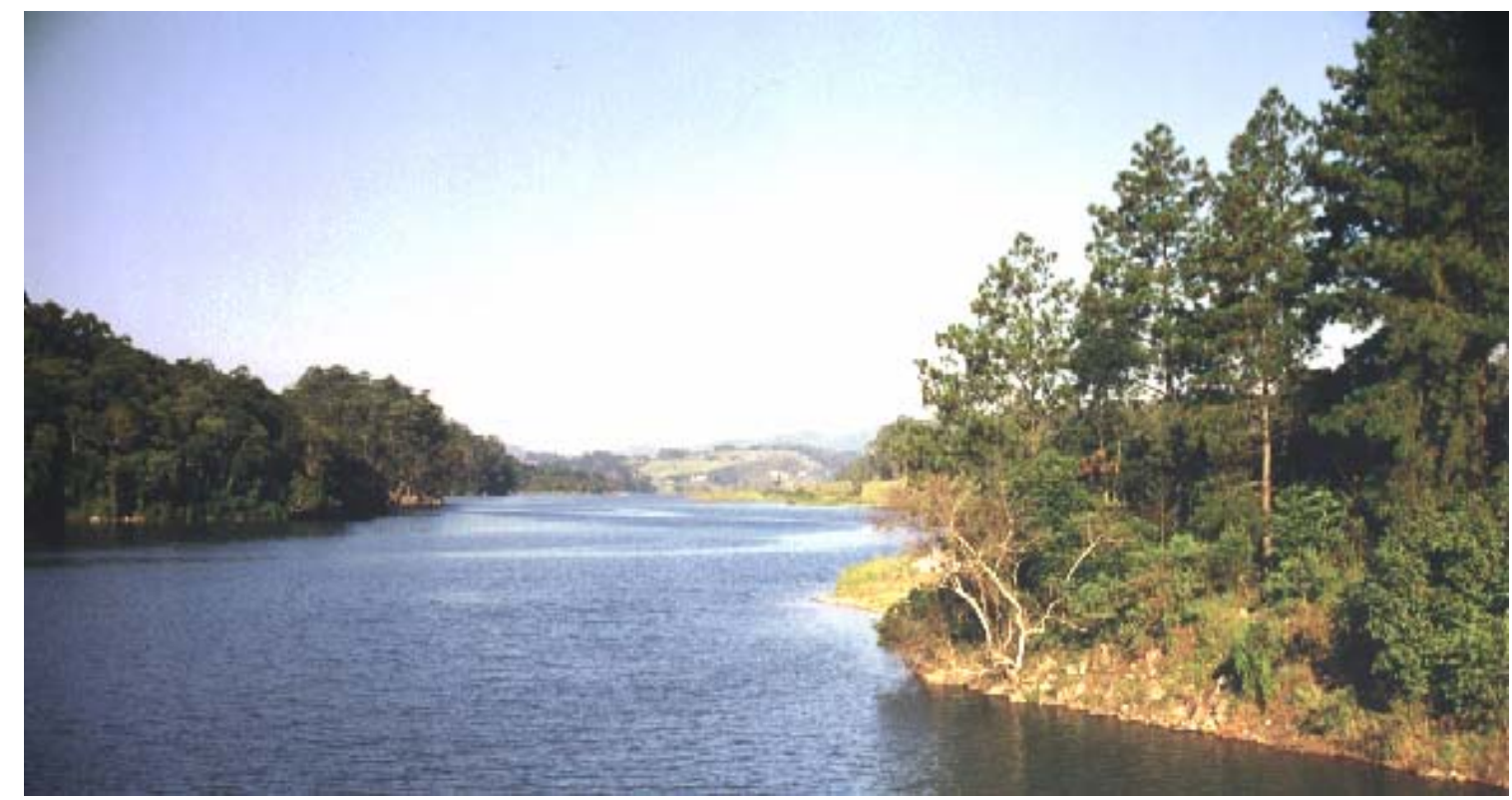

Foto 1: Reservatório Paiva Castro visto da Barragem no município de Franco da Rocha-SP $(06 / 04 / 2000)$ 


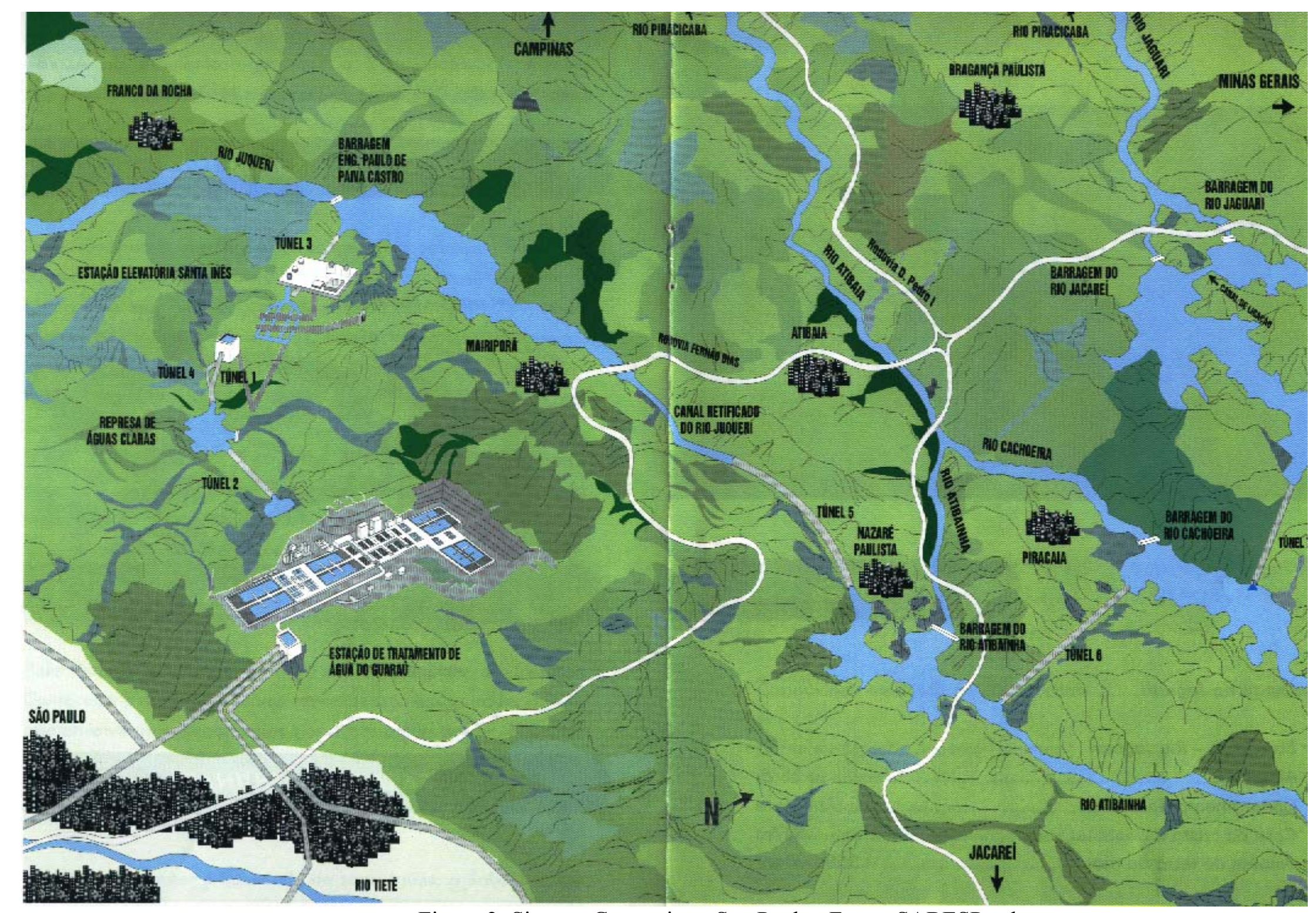

Figura 2: Sistema Cantareira - São Paulo Fonte: SABESP, sd. 


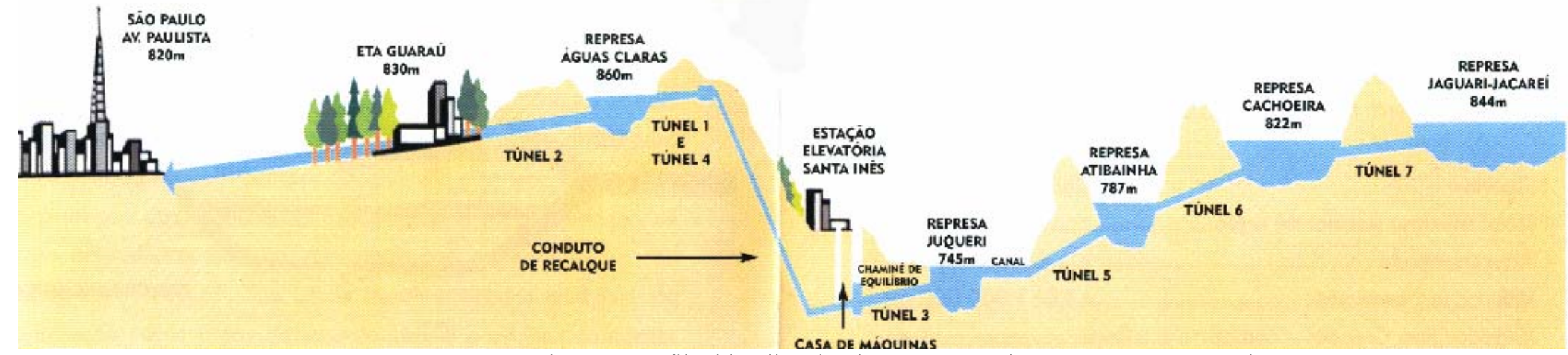

Figura 3: Perfil Hidráulico do Sistema Cantareira Fonte: SABESP, sd. 


\subsection{O MUNICÍPIO DE MAIRIPORÃ E O RESERVATÓRIO PAIVA CASTRO}

O povoamento da região iniciou-se por volta de 1600 com a distribuição das sesmarias pela coroa portuguesa. Este povoado que inicialmente era conhecido como Juqueri ficava relativamente isolado da Capitania de São Paulo, quando em 1890 com a construção da estrada de ferro Santos - Jundiaí tornou-se rota do escoamento da produção de café do interior paulista. Porém, só em 1948 passou a ser chamada de Mairiporã, nome de origem tupí-guaraní que significa cidade bonita (BORN, 2000).

Tendo sua localização geográfica em latitude S 23021'25" e longitude W 4652'40", o município de Mairiporã possui limites com os municípios de São Paulo, Atibaia, Nazaré Paulista, Guarulhos, Caieiras e Franco da Rocha (EMPLASA, 1999). Sua área total é de $307,0 \mathrm{~km}^{2}$ dos quais $114 \mathrm{~km}^{2}$ representam área urbanizada, sendo que $80,1 \%$ do total situa-se dentro da área da Lei de Proteção aos Mananciais (EMPLASA, 2000). Sua topografia é montanhosa com altitudes de $875 \mathrm{~m}$ na cidade. A vegetação nativa é densa e o solo é argiloso e arenoso. O município possui $117 \mathrm{~km}$ de vias urbanas pavimentadas (AZEVEDO, 2000) e as suas principais atividades econômicas são a indústria e a agricultura (BORN, 2000).

No vale do Juquerí - área da represa e da sede do município - as condições climáticas predominantes são as de clima tropical de altitude, com precipitações variando entre $1500 \mathrm{~mm}$ e $1800 \mathrm{~mm}$, com nebulosidade maior nos altos da Cantareira. As temperaturas médias da região oscilam entre $20-21^{\circ}$ para os fundos do vale e $18-19^{\circ}$ para as duas cimeiras principais das serras que enquadram o médio vale do Juquerí - serras da Cantareira e do Juquerí (Ab'Saber, 1978).

O reservatório Paiva Castro, a jusante da cidade, possui sua "cauda" dentro do próprio perímetro urbano do município de Mairiporã (foto 2), que em 1970 contava com 4.000 habitantes (AB'SÁBER, 1978), tendo registrado, no último recenseamento, a população de 49.893 habitantes (FUNDAÇÃO IBGE, 1996 apud CBH-AT - Comitê da Bacia Hidrográfica do Alto Tietê, 1997), e mais recentemente, 55.888 habitantes (EMPLASA, 1999). 


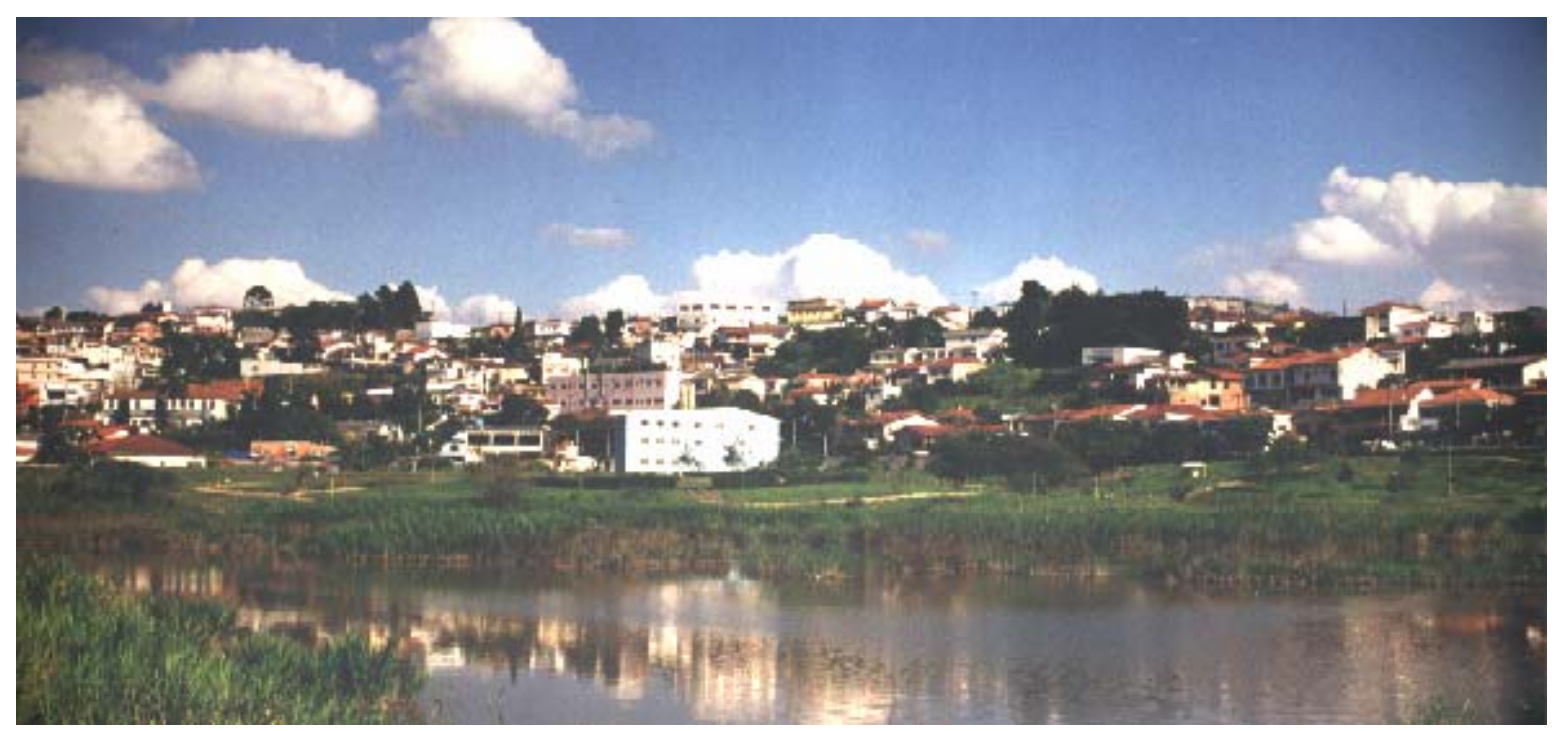

Foto 2: A área urbana do município de Mairiporã e "cauda" do reservatório Paiva Castro $(06 / 04 / 2000)$.

O espantoso crescimento demográfico na região já havia sido previsto por estudos sócio-econômicos realizados pelo IF (Instituto Florestal, 1974) na região, indicando crescimento acentuado da população para os municípios situados na região da Cantareira, com tendências de expansão no sentido Leste-Oeste, portanto, paralelamente ao maciço da Cantareira, incluindo aí o município de Mairiporã.

Além de manancial extremamente importante para a Grande São Paulo, o reservatório Paiva Castro também constitui uma opção de lazer para diversos moradores de Mairiporã, Guarulhos, Caieiras e da zona norte do município de São Paulo. A área da represa e do canal do Rio Juquerí chega a receber entre 7.000 e 15.000 visitantes aos finais de semana, sendo que a "prainha", situada no canal do rio, é o local mais visitado, capaz de atrair cerca de 5.000 pessoas nos finais de semana ensolarados (BORN, 2000).

Por ser o receptor final do sistema, o reservatório Paiva Castro pode refletir a qualidade final da água bruta a ser enviada à ETA do Guaraú. Estando o reservatório alojado entre a crista da Serra da Cantareira e a da Serra do Juquerí, este se torna passível da recepção das cargas poluidoras, principalmente de origem doméstica, do município de Mairiporã.

É importante registrar que os principais problemas do município são relativos a saneamento básico além do déficit de 2.000 casas e infra-estrutura básica. Grande parte da 
população não é beneficiada com água encanada e parte dos esgotos, devido a precariedade da rede de captação, é lançada diretamente no reservatório Paiva Castro. As ligações de água atendem 82\%, enquanto as de esgoto contemplam 50\% das residências (EMPLASA, 1999). Segundo AZEVEDO (2000) existem 7.500 ligações de água no município e apenas 3.000 ligações de esgoto.

Neste município não existem serviços básicos suficientes e infra-estrutura adequada. O crescimento demográfico e a falta de um plano diretor geram dificuldades para a população. Grande parte dos moradores trabalha em outros municípios, caracterizando Mairiporã como cidade dormitório. Isso ocorre pela sua proximidade com a capital, fato que aliado ao baixo preço dos lotes incentivou diversas pessoas a comprarem lotes para construir moradias. Neste caso, inúmeras parcelas em área de proteção de mananciais passaram a ser loteadas e ocupadas irregularmente gerando novos bairros (BORN, 2000) em áreas passíveis de comprometer o reservatório Paiva Castro e conseqüentemente as águas do Sistema Cantareira.

O município de Mairiporã conta com uma estação de tratamento de esgotos (foto 3) do tipo lagoa de estabilização operada pela SABESP. Este sistema é composto por duas lagoas anaeróbias (somando $15.336 \mathrm{~m}^{3}$ de volume) e duas lagoas facultativas (somando $23.312 \mathrm{~m}^{3}$ de volume), perfazendo um total de $38.648 \mathrm{~m}^{3}$ de volume (CETESB, 1974). No entanto, há algumas ressalvas com relação à capacidade de tratamento desta estação de tratamento de esgotos, tendo em vista o assoreamento das lagoas ocorrido em função do tempo de operação sem contar com manutenção e desassoreamento.

De acordo com informações obtidas com a Engenheira Paula Rosolino, gerente do Setor de Sistemas Isolados Norte - MNED.3 da SABESP de Mairiporã, apenas uma das lagoas anaeróbias passou por um processo de desassoreamento, cujo qual, não possui registro de data, no entanto, há um projeto, com orçamento previsto pela SABESP em vias de licitação, com a finalidade de adequar tal estação de tratamento de esgotos às demandas do município. Este projeto consiste de duas etapas, sendo a primeira a construção de dois reatores anaeróbios de fluxo ascendente mais um filtro biológico no intuito de atender a uma vazão de 60 litros de esgotos domésticos por segundo; a segunda etapa deste projeto 
corresponde à construção de estrutura equivalente objetivando duplicar a vazão da ETE para $120 \mathrm{l} / \mathrm{s}$.

A SABESP adota o processo de cloração do efluente da estação de tratamento de esgotos como medida contínua a fim de oxidar os elementos orgânicos e destruir organismos patogênicos remanescentes do tratamento. Este processo de cloração não é uma medida muito recomendável para a desinfecção dos esgotos, devendo ser utilizado apenas em situações emergenciais. Nessas situações é comum que partículas grandes contendo microrganismos protejam estes da ação do cloro. Outro fato importante é que o cloro provoca efeitos adversos nos ecossistemas aquáticos dos corpos d'água receptores (PIVELI, 1998).

Cabe afirmar que as ligações de esgoto atendidas pela estação de tratamento, situam-se na região central da cidade e que, diversos bairros afastados não são contemplados por tais ligações e seus esgotos correm em direção ao manancial sem qualquer tipo de tratamento prévio. Ainda nas proximidades da região central da cidade, o bairro conhecido como Barreiro, pertencente a uma outra vertente que não a de drenagem dos esgotos para a estação de tratamento, portanto, destina grande quantidade de cargas poluidoras para o reservatório Paiva Castro através de um afluente, o ribeirão Barreiro. Estas informações foram verificadas em campo com o auxílio da Equipe de Proteção aos Mananciais, na pessoa do Sr. Márcio Monteiro da Paixão.

Os efluentes da estação de tratamento de esgotos do município são lançados no córrego Itaim, afluente do Rio Juquerí à montante do reservatório Paiva Castro.

O rio Juquerí, bem como todos os seus afluentes até a barragem da SABESP enquadram-se na Classe I da legislação estadual paulista referente aos recursos hídricos superficiais (lei no 997/76, regulamentada pelo decreto 8.468/76), isto significa que suas águas são destinadas ao abastecimento doméstico sem tratamento prévio ou com simples desinfecção; também determinando que qualquer tipo de lançamento de esgoto, mesmo tratado, é proibido em corpos d'água desta categoria (CETESB, 1982). 


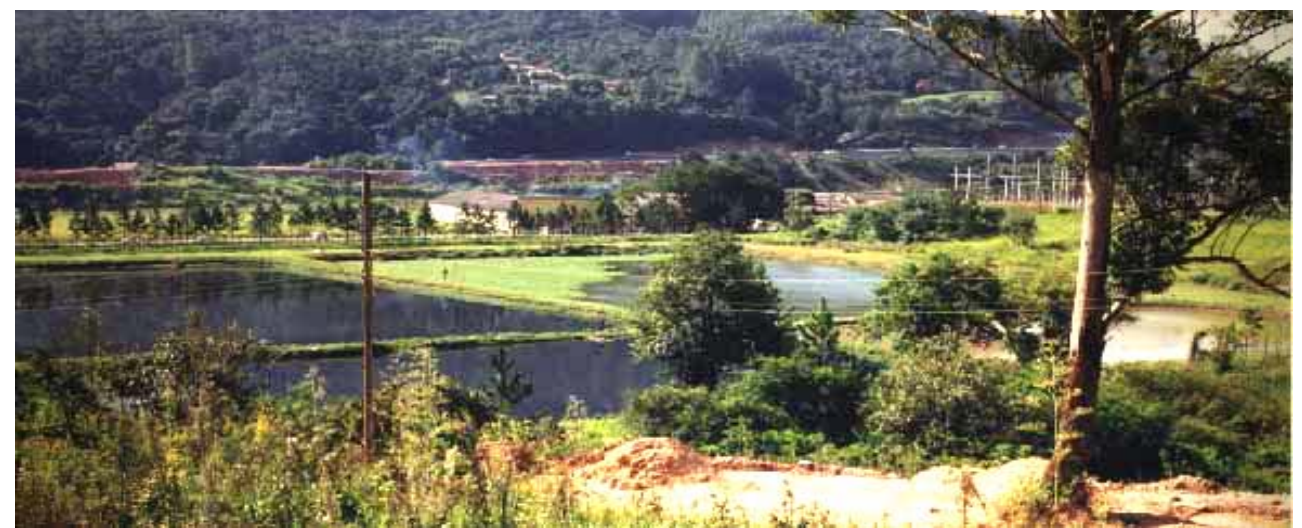

Foto 3: Estação de Tratamento de Esgotos de Mairiporã, ao fundo Rodovia Fernão Dias e canal retificado do Rio Juquerí (06/04/2000).

A captação de água para o município de Mairiporã é feita no próprio reservatório, portanto, à jusante do lançamento do efluente da estação de tratamento de esgotos do município (foto 4). A CETESB (1976), em relatório de inspeção sanitária e amostragem no sistema de abastecimento de água do município, verificou que a estação de tratamento de água, que acabava de entrar em operação e que era abastecida em maior volume pelo reservatório, deveria urgentemente adotar um procedimento de pré-cloração e aumento na dosagem da aplicação de cloro no final do tratamento. Estes procedimentos foram sugeridos em função dos altos índices de bactérias coliformes encontrados nas águas tratadas. Vale registrar que este processo de pré-cloração permanece como regra operacional para esta estação de tratamento de água até a atualidade.

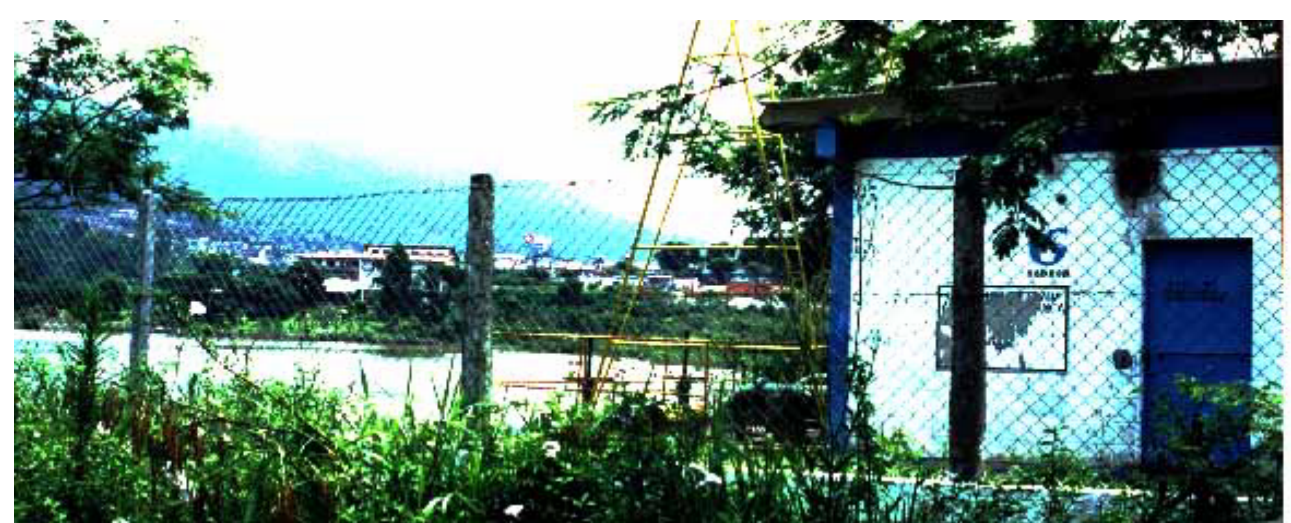

Foto 4: Captação de água da SABESP - Mairiporã, ao fundo reservatório Paiva Castro e a área urbana do município (03/11/2000). 


\subsection{DESENVOLVIMENTO ECONÔMICO DA REGIÃO}

Paralelamente à implantação do Sistema Cantareira a região foi apresentando grande desenvolvimento econômico. Destaca-se o término da pavimentação e inauguração da Rodovia Fernão Dias em 1961 integrando, juntamente com as rodovias Presidente Dutra e Juscelino Kubitscheck, o "Triângulo Econômico do Brasil" cujos vértices são constituídos pelas três regiões metropolitanas mais populosas do país: as de São Paulo, Rio de Janeiro e Belo Horizonte (DNER, 1993a).

Posteriormente, ocorreu a construção dos reservatórios que a partir de 1969 caracterizou dois momentos distintos na economia da região; antes da instalação das represas, quando a economia era baseada na agropecuária e depois, quando esta atividade tornou-se inviável em virtude da inundação de extensas áreas, iniciando movimentação da população do campo em direção as cidades originando problemas sociais.

As obras das represas, ocorridas no contexto político autoritário do final dos anos 60 , seguem a característica geral da implantação dos grandes empreendimentos públicos do período da ditadura militar. Tais empreendimentos realizavam-se sem um trabalho prévio de sensibilização da população, acarretando, além de mudanças no espaço físico das atividades produtivas, profundas alterações no modo de vida, na esfera afetiva e nas relações culturais mantidas por gerações. O impacto da perda do referencial de vida da população desalojada manifestou-se muitas vezes de forma intensa, inclusive por relatos de casos de suicídio, morte por tristeza e desânimo com a vida. A geração de mais idade foi em geral a mais afetada por falta de motivação para reiniciar novas atividades em outras áreas (HOEFEL e VIANA, 1996).

Particularmente, Mairiporã sofreu um grande impacto econômico com a construção e enchimento do reservatório Paiva Castro. Anteriormente a este evento, o município contava com mais de 300 olarias nos vales da bacia do rio Juquerí (foto 5), estas empregavam aproximadamente 5.000 trabalhadores e produziam cerca de 900 milhões de tijolos/ano, atendendo a demanda do crescimento urbano da metrópole paulista. Algumas 
indústrias locais também foram afetadas pelas obras de implantação do Sistema Cantareira (BORN, 2000)

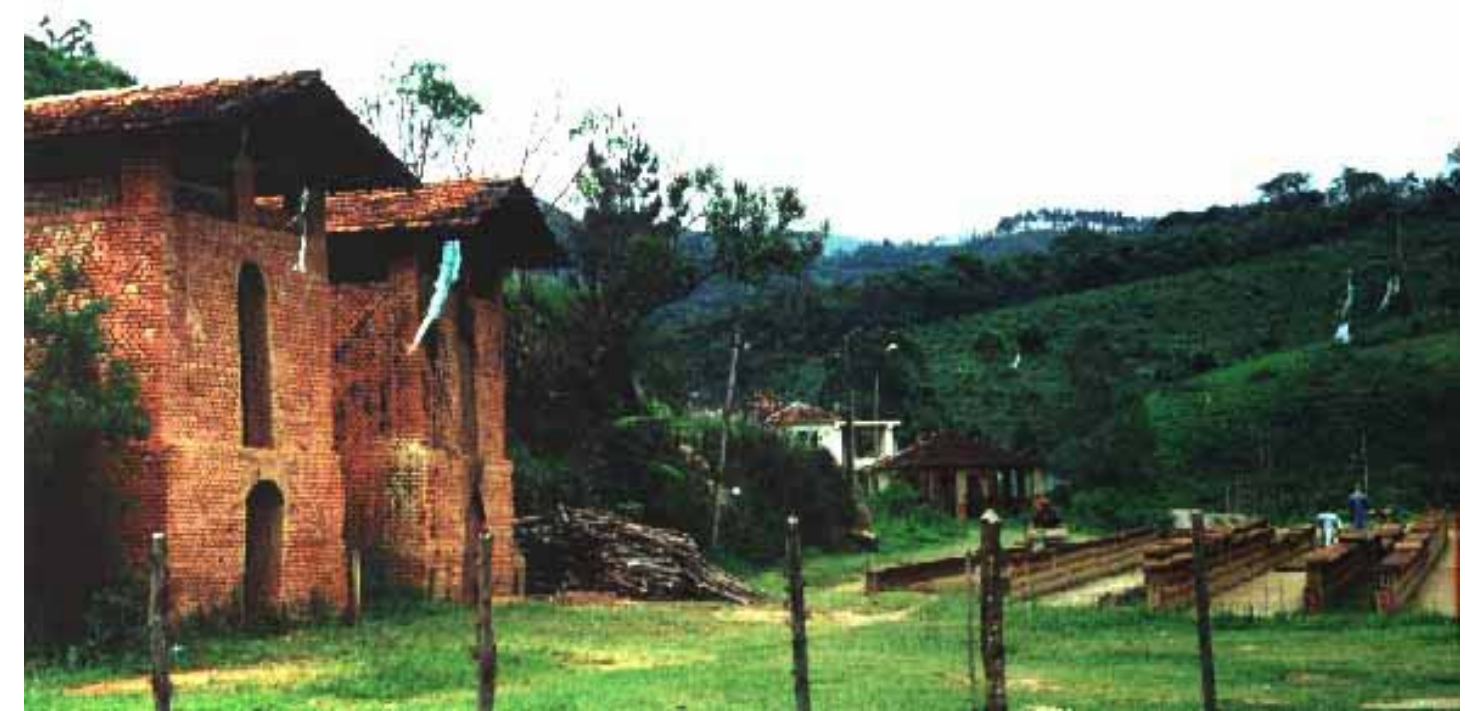

Foto 5: Esta olaria continua operando por estar localizada na Vila Ponte Alta, à montante da área inundada pelo reservatório $(03 / 11 / 2000)$.

A seguir, na década de 70 a abertura da Rodovia Dom Pedro I, que tornou o acesso à região mais fácil, também propiciou mudanças na estrutura fundiária, sendo que frente a decadência da agropecuária muitos proprietários venderam suas terras, iniciando-se então, os desmembramentos de propriedades e implantação de chácaras de lazer, também caracterizando os municípios como as chamadas "cidades dormitórios".

Com o andamento das obras da duplicação da Rodovia Fernão Dias o acesso à região é ainda mais facilitado, propiciando o aumento das populações fixas e flutuantes nos municípios de abrangência (SÃO PAULO - ESTADO, 1998).

Em determinados lotes, as obras da duplicação da Rodovia Fernão Dias (foto 6) podem interferir sobre a qualidade das águas dos mananciais do Sistema Cantareira de abastecimento da Região Metropolitana de São Paulo. Em se tratando dos recursos hídricos os principais impactos relacionados à duplicação da Rodovia podem ser: risco de contaminação e poluição de mananciais, assoreamento do leito de rios e reservatórios, aumento da turbidez 
das águas de rios e reservatórios e interferências sobre a qualidade das águas de aqüíferos subterrâneos. Quanto a estrutura urbana, uso e ocupação do solo podem sofrer impactos com relocações, desapropriações, segregações urbanas, reforço nas tendências de uso e ocupação do solo e alteração do uso e ocupação do solo. No meio sócio-econômico vem a confirmar e reforçar as tendências já vigentes de sua dinâmica em virtude da melhoria da acessibilidade no âmbito regional (DNER, 1993b).

A duplicação da rodovia Fernão Dias ainda acabará por fortalecer o eixo de ligação da Região Metropolitana de São Paulo com os parques industriais instalados no sul do Estado de Minas Gerais, em especial, o parque industrial do Município de Estrema, MG. O território mineiro, por ter a aplicação da legislação ambiental com formato menos rigoroso do que o Estado de São Paulo, oferece a possibilidade das cidades mineiras vizinhas à Bragança Paulista desenvolverem os referidos parques industriais que provocam impactos e pressionam de forma efetiva os recursos hídricos da região (HOEFEL e VIANA, 1996).

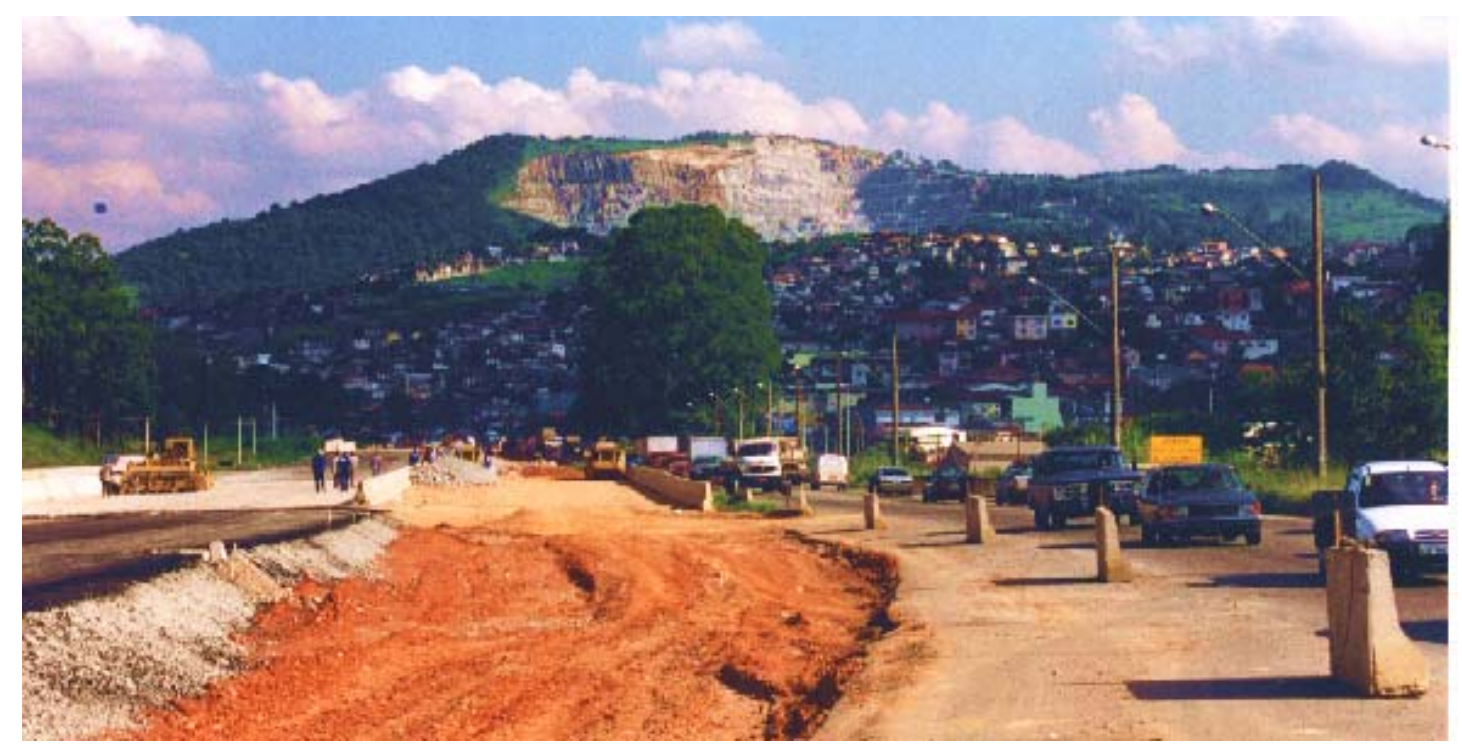

Foto 6: Obras de duplicação da Rodovia Fernão Dias na altura da ponte sobre o Rio Juquerí $(06 / 04 / 2000)$.

Frente à possibilidade da construção do chamado Rodoanel contornando a Região Metropolitana de São Paulo surgem novas possibilidades de atividades impactantes aos mananciais, colocando em maior risco a produção e qualidade da água do Sistema 
Cantareira. A construção do Rodoanel é justificada pela problemática dos transportes na área metropolitana (FESPSP- Fundação Escola de Sociologia e Política de São Paulo, 1997).

Entre os riscos de impacto aos mananciais provenientes do desenvolvimento da malha viária, vale destacar que o Sistema Cantareira apresenta ao longo de suas derivações algumas fragilidades no que tange aos riscos de contaminação e/ou poluição dos mananciais por acidentes envolvendo veículos do transporte rodoviário de cargas tóxicas. Só no município de Mairiporã - SP, a Rodovia Fernão Dias adentra a área drenante ao Reservatório Paiva Castro no Rio Juquerí, interceptando alguns cursos d'água e talvegues naturais em uma extensão de aproximadamente $10 \mathrm{Km}$, incluindo-se a travessia da rodovia por sobre o canal do rio (DNER - Departamento Nacional de Estradas de Rodagem, 1993b).

O processo de urbanização na grande metrópole paulista acelerou-se muito e a mancha urbana atingiu significativamente locais desfavoráveis, gerando conflitos sócioambientais inerentes aos usos urbanos do solo, tais como habitação, proteção ambiental, especulação imobiliária e proteção de recursos hídricos, exigindo do poder público maior participação através de políticas e diretrizes de planejamento físico territorial.

Dentro deste contexto foi elaborada, na década de 70, a Lei Estadual de Proteção de Mananciais, com o objetivo de gerir a associação entre o uso do solo e a qualidade e quantidade das águas destinadas ao abastecimento público, objetivando exercer funções modeladoras do crescimento metropolitano.

Porém, na prática, a Lei de Proteção de Mananciais não é rigorosamente obedecida, gerando tipos e ocupações de solo transgressores à legislação e acarretando conseqüências ao ambiente natural (MOROZ, 1993).

Algumas dificuldades na aplicação desta legislação ocorriam devido as restrições estabelecidas serem generalizadas sem que se considerasse as particularidades de cada região. Nesse sentido um importante avanço foi dado em 1997 com a elaboração da nova Lei Estadual de Proteção de Mananciais - N N $^{0}$ 9.866/97 - sendo que esta determinava subregiões, as quais podem elaborar sua lei específica seguindo predisposições da lei geral (SÃO PAULO - ESTADO, 1997). 
O reservatório Paiva Castro, por estar localizado dentro da Região Metropolitana de São Paulo está compreendido na sub-região Juquerí-Cantareira, integrando a Unidade de Gestão de Recursos Hídricos do Alto Tietê. No entanto, os demais reservatórios do Sistema Cantareira integram a Unidade de Gestão dos rios Piracicaba, Capivari e Jundiaí, fato este, que evidencia dificuldades no processo decisório que envolve o Sistema Cantareira como um todo (SÃO PAULO - ESTADO, 1997).

Porém, mesmo com a legislação pertinente em vigor o município de Mairiporã, com $80,1 \%$ de sua área total sob proteção de mananciais, não está a salvo dos problemas oriundos de uma urbanização desenfreada.

Segundo JACOBI (1995) os problemas ambientais decorrem do impacto da urbanização predatória sobre o ecossistema, retratando os efeitos da ausência de uma política que atenda o crescente déficit de habitação para a população de baixa renda, que tem principalmente as áreas de proteção de mananciais como a sua última alternativa de posse e moradia. A degradação ambiental é significativa pela exiguidade de rede de esgotos e seu tratamento, a descarga pouco controlada dos dejetos tóxicos industriais e comerciais, além dos problemas de destinação do lixo e da contaminação do ar que incidem na qualidade da água dos mananciais.

Mesmo com a determinação de Áreas de Proteção Ambiental - como a da Bacia do Rio Piracicaba e da Bacia do Rio Juquerí-Mirim - e com a crescente restrição e maior fiscalização sobre as atividades produtivas impactantes no Estado de São Paulo, surgem dificuldades do ponto de vista político provenientes da pulverização das responsabilidades entre órgãos diversos, gerando incapacidade de atuar no contexto global de uma bacia hidrográfica que ultrapassa os limites estaduais e exige uma integração de visão e ação entre várias instituições e níveis de sociedade (HOEFEL e VIANA, 1996).

Estudos do DAEE (Departamento de Águas e Energia Elétrica do Estado de São Paulo, 1966) sobre as possibilidades de implantação do Sistema Cantareira na região fizeram previsões relativas ao desenvolvimento econômico, onde já se encontravam estabelecidos núcleos urbanos e industriais de grande expressão e que no futuro apresentariam importante crescimento. 
Estes elementos deveriam ser suficientes para alertar sobre os riscos de poluição aos quais o sistema seria exposto, porém, nas condições atuais, o reservatório Paiva Castro, bem como todas as águas do Sistema Cantareira, estão sob constante ameaça de atividades antrópicas impactantes. 


\subsection{EFEITOS DA POLUIÇÃO EM RESERVATÓRIOS}

A contínua expansão da área metropolitana das cidades traz, como uma de suas notórias conseqüências, o problema da poluição das águas superficiais em geral, uma vez que resíduos domésticos e industriais, de um modo ou de outro, têm acesso aos cursos d'água, modificando acentuadamente sua composição e características. No caso específico da proteção de recurso hídrico que será utilizado exclusivamente para o abastecimento de água potável, temos a considerar o seguinte: de um lado, os padrões mínimos de qualidade que deverão ser mantidos na água in natura; e, de outro lado, os inúmeros fatores que, decorrentes do uso da terra, poderão interferir nessa qualidade. (BRANCO e ROCHA, 1977). Portanto, há de se considerar a possível associação da evolução dos parâmetros da qualidade da água com o crescimento populacional e o uso e ocupação do solo na região de estudo.

Os prejuízos da poluição aos mananciais podem ser referentes à destruição da fauna e flora, decorrentes da alteração do teor de oxigênio, matéria orgânica, $\mathrm{pH}$, temperatura, etc, ou referentes à saúde pública, sendo relacionados principalmente a critérios bacteriológicos, que interferem diretamente nos processos de potabilização das águas naturais.

A forte poluição, além de causar danos a bióta aquática e aos padrões mínimos de qualidade da água para abastecimento, pode caracterizar um processo de fertilização do corpo d'água, como no caso de lançamento de esgotos domésticos que após a degradação biológica favorecem o processo de eutrofização (BRANCO, 1986).

A eutrofização é o aumento da concentração de nutrientes, especialmente fósforo e nitrogênio, nos ecossistemas aquáticos, que tem como conseqüência o aumento de suas produtividades. Como decorrência deste processo, o ecossistema aquático passa da condição de oligotrófico e mesotrófico para eutrófico ou mesmo hipereutrófico, acarretando profundas modificações qualitativas e quantitativas nas comunidades aquáticas, nas condições físicas e químicas do meio e no nível de produção do ecossistema, podendo ser considerada uma forma de poluição. A eutrofização artificial das águas continentais está relacionada com o aumento da população, da industrialização, do uso de fertilizantes químicos na agricultura e 
com a produção, desde 1945, de produtos de limpeza contendo compostos poliofosfatados (ESTEVES, 1998).

Sob essas condições tróficas, um ambiente lêntico como um reservatório tornase passível da ocorrência do fenômeno da floração de algas que consiste da proliferação excessiva destes organismos planctônicos ou bentônicos devido a fatores extremamente favoráveis ao seu crescimento; acarretando a formação de verdadeiras massas ou "ilhas flutuantes", ou mesmo tapetes de algas cobrindo grandes extensões de água. Essas massas, podem, algumas vezes, ser deslocadas pelo vento, acumulando-se nas enseadas dos lagos e represas, junto às margens, onde se decompõem, causando forte mau cheiro, podendo liberar substâncias tóxicas ou causar mortandade de peixes por asfixia devido ao elevado consumo de oxigênio no processo de decomposição (BRANCO, 1986).

Segundo DI BERNARDO (1995) "o florecimento algal decorrente do aumento da concentração de nutrientes no manancial pode ter os seguintes efeitos diretos na qualidade da água: a) aumento da matéria orgânica particulada (fitoplâncton, zooplâncton, bactérias, protozoários, fungos e detritos); b) aumento de substâncias orgânicas dissolvidas que podem conferir sabor e odor à água, ser percursores de formação de compostos organoclorados, incrementar a cor da água, servir de substrato para o crescimento de bactérias na estação de tratamento e no sistema de distribuição e contribuir para aumentar a corrosão; c) aumento do pH e de suas flutuações diárias; d) diminuição do teor de oxigênio próximo ao sedimento, podendo ocorrer liberação de sulfeto de hidrogênio, amônia, ferro, manganês, fósforo, etc". Essas alterações na qualidade da água bruta, podem causar efeitos diretos e indiretos nos processos de captação, tratamento e distribuição de água, acarretando maior ônus, seja com manutenção de equipamentos ou mesmo com maior utilização de insumos químicos.

Uma questão extremamente relevante dentro desta problemática da floração de algas é a ocorrência de algas cianofíceas, também conhecidas como cianobactérias ou algas azuis, sendo que algumas espécies deste grupo apresentam cepas produtoras de toxinas (BRANCO, 1986). 
Em ambientes lacustres, algumas cianofíceas possuem a capacidade de adaptação de seus pigmentos à radiação solar, permitindo uma maior produtividade mesmo em profundidades maiores, além do que, algumas espécies possuem vacúolos gasosos como adaptação para a flutuação, facilitando sua aproximação com a superfície também melhorando sua produtividade e conseqüente crescimento. Tais capacidades adaptativas fazem com que estas algas apresentem vantagens competitivas em ambientes lênticos como os reservatórios (ESTEVES, 1998).

Quanto ao tratamento para potabilização de água in natura, este processo, realizado em estações de tratamento de água, quando convencional é limitado na sua capacidade de remoção de impurezas, as quais podem ser oriundas de diversas fontes poluidoras como esgotos domésticos, industriais, ou mesmo de eutrofização. Portanto, nos casos em que os níveis de impurezas são elevados é necessário recorrer a métodos especiais de tratamento, que oneram economicamente o processo (BRANCO e ROCHA, 1977).

\section{JUSTIFICATIVA}

Diante do exposto e considerando que o Sistema Cantareira é o mais importante manancial de abastecimento da metrópole, o qual foi projetado e construído justamente com este propósito, fica clara a importância e a necessidade da realização de estudos que possam subsidiar o controle preventivo e corretivo no sentido de minimizar os impactos da poluição e preservar este fundamental recurso hídrico. 


\section{OBJETIVOS}

\section{GERAL}

Estudar o comportamento de parâmetros de qualidade de água no reservatório Paiva Castro, registrados em série histórica fornecida pela SABESP (Companhia de Saneamento Básico do Estado de São Paulo) e CETESB (Companhia de Tecnologia de Saneamento Ambiental do Estado de São Paulo), capazes de refletir o comprometimento da água no tocante as exigências mínimas para sua potabilização, considerando o crescimento populacional no município de Mairioporã/SP de 1987 à 1998.

\section{ESPECÍFICOS}

- Analisar parâmetros disponíveis em série histórica e capazes de indicar o comprometimento do corpo d'água por esgotos domésticos com atenção àqueles relevantes no processo de tratamento para potabilização da água;

- Analisar os pontos de amostragem com base na estrutura urbana do município, localizando as possíveis fontes poluidoras;

- Analisar estatisticamente as médias anuais dos parâmetros de qualidade de água procurando identificar sua possível associação com o crescimento populacional e uso e ocupação do solo;

- Verificar a possível contribuição de poluentes provenientes de esgotos domésticos lançados no reservatório a partir da estação de tratamento de esgotos do município. 


\section{MATERIAL E MÉTODOS}

Em se tratando de estudo fundamentado, principalmente, sobre dados secundários, torna-se imprescindível uma caracterização dos bancos de dados a serem utilizados na pesquisa e disponíveis em instituições estatais.

A principal fonte de informações para este estudo consiste de um banco de dados existente na SABESP - Companhia de Saneamento Básico do Estado de São Paulo (1999) e que permitiu o seu uso para os estudos e pesquisas referentes à esta dissertação.

Nesse sentido há um protocolo de cooperação firmado entre a referida companhia e o Departamento de Saúde Ambiental da Faculdade de Saúde Pública da USP para a participação conjunta na realização de estudos ambientais nas bacias hidrográficas do Sistema Cantareira e seu sistema de abastecimento integrado por um conjunto de mananciais, incluindo o reservatório Paiva Castro. Este amplo programa recebe auxílio da FAPESP (Fundação de Apoio à Pesquisa do Estado de São Paulo).

Os dados cedidos pela SABESP compreendem informações obtidas de amostragem em diversos pontos de coleta ao longo de todos os reservatórios, bem como, de tributários do sistema, disponibilizando registros em série histórica de 1987 à 1998.

$\mathrm{Na}$ área de interesse compreendida neste estudo há quatro pontos de amostragem no corpo do reservatório Paiva Castro (incluindo amostragem em profundidade), sete pontos em seus contribuintes na bacia e outros três pontos em seu escoamento.

O exame dos resultados permite verificar haver uma periodicidade parcial, tanto no que diz respeito à freqüência de coleta em cada ponto como quanto à análise de determinados parâmetros.

Estas características definitivamente evidenciam que o trabalho dessa conceituada empresa de saneamento atendem a um programa de vigilância da qualidade da água que contempla os padrões mínimos exigidos pela legislação e relevantes ao tratamento e potabilização do recurso hídrico. 
Uma outra fonte de informações está contida nos Relatórios de Qualidade das Águas Interiores do Estado de São Paulo, emitidos pela CETESB - Companhia de Tecnologia de Saneamento Ambiental do Estado de São Paulo (1978 à 1998). No intuito de se fazer comparações com dados da SABESP, foram selecionados para este estudo apenas os relatórios com dados de 1987-1998.

Com respeito a esse trabalho da CETESB deve ser assinalado que há apenas um ponto de amostragem em todo o Sistema Cantareira. Este está situado no reservatório Paiva Castro, onde é realizado um monitoramento freqüente, fornecendo registros desde 1978.

Vale dizer que o ponto de amostragem da CETESB coincide com um dos pontos no reservatório utilizados pela SABESP, permitindo então, a elaboração de um quadro comparativo entre os dados fornecidos por ambos.

Uma adequada seleção de pontos e parâmetros constantes desta grande quantidade de dados permitiu obter informações relevantes para uma análise estatística com intuito de verificar a qualidade da água no reservatório e seu comportamento ao longo do tempo.

As atividades constantes do método utilizadas para o desenvolvimento deste estudo foram as seguintes:

- Acompanhamento das atividades de campo e laboratório para o monitoramento realizado tanto pela SABESP quanto pela CETESB destinadas à amostragem e análise laboratorial dos parâmetros de qualidade de água que seguem o Guia de Coleta e Preservação de Amostras (CETESB, 1988) e Standard Methods for the Examination of Water and Wastewater $19^{\text {th }}$ ed. (SABESP).

- Análise estatística de dados de qualidade de água verificando o comportamento ao longo do tempo;

- Pesquisa institucional visando conhecer o adensamento urbano, crescimento populacional e desenvolvimento de infra-estrutura na região de estudo; 
- Análise de dados de crescimento populacional relacionados à evolução dos parâmetros de qualidade de água.

- Acompanhamento do trabalho de fiscalização de mananciais realizado pela SABESP no município de Mairiporã pela Equipe de Proteção aos Mananciais com sede na Elevatória Santa Inês situada no próprio município.

Quanto às características dos bancos de dados, primeiramente deve-se citar que os dados fornecidos pela CETESB constam em publicações anuais, onde os resultados dos parâmetros são apresentados em planilha respectiva ao ponto de coleta apresentando os valores de acordo com periodicidade das amostragens, que geralmente é bimestral.

Porém, o banco de dados fornecidos pela SABESP, principal eixo de estudo, apresenta-se como um arquivo eletrônico, onde os dados foram sendo registrados ao longo do tempo, colocando todos os pontos de amostragem e seus respectivos parâmetros dispostos exclusivamente na ordem em que foram surgindo os resultados. Portanto, este conjunto de informações precisa ser segregado levando-se em consideração os pontos de interesse no estudo bem como os parâmetros a se analisar.

Visando definir a melhor maneira de segregar e dispor as informações do banco de dados da SABESP, bem como, verificar a periodicidade de amostragem e de registro de determinados parâmetros, foi realizado um ensaio compondo uma planilha de um determinado ponto de amostragem, esta serviu de modelo para constituição das demais planilhas relevantes ao estudo.

O ponto de coleta selecionado, que possui a denominação de PC-215, situa-se no Rio Juquerí à montante do reservatório Paiva Castro e à jusante do lançamento de efluente da estação de tratamento de esgotos de Mairiporã. Seu posicionamento, à jusante dos lançamentos dos efluentes da estação de tratamento de esgotos de Mairiporã, justifica, portanto, a importância de sua inclusão no estudo.

Os demais pontos selecionados foram (vide imagem de satélite em Anexo): 
- Nos tributários: PC-301 - saída do túnel que conduz as águas dos reservatórios à montante para o Rio Juquerí, PC-210 - águas do Rio Juquerí antes da mistura com águas dos demais reservatórios, PC-212 - Rio Pinheiros, PC-214 - Ribeirão Itaim onde ocorre o lançamento do efluente da estação de tratamento de esgotos de Mairiporã PC-217A - no Ribeirão Barreiro;

- No reservatório: PC-104, PC-103, PC-102 - este último coincidente com o ponto de coleta de amostras da CETESB;

- Na captação da Elevatória Santa Inês: PC-002.

É importante destacar que para a escolha dos pontos de coleta componentes deste estudo foram levadas em consideração as seguintes premissas: os pontos selecionados estarem compreendidos entre o circuito formado pelos tributários e a captação de água na Elevatória Santa Inês; apresentarem importância sanitária, sendo capazes de demonstrar o eventual aporte de cargas poluidoras no manancial; caracterizarem a possível depuração destas cargas poluidoras ao longo do manancial até o ponto de captação.

Os pontos PC-104, PC-103 e PC-102, situados no corpo do reservatório possuíam algumas amostragens feitas em profundidade, no entanto, pela insuficiência dos dados existentes para as diversas profundidades, foi decidido que se deveria fazer uso apenas dos dados disponíveis de coletas de superfície, capazes de integrar as respectivas planilhas.

Com respeito à nomenclatura dos pontos de coleta da SABESP, verifica-se que esta é composta das letras "PC" iniciais do nome do reservatório Paiva Castro, sendo que os números subseqüentes determinam em seu primeiro dígito se o ponto corresponde a tributário (2), represa (1), efluente (0) ou transferência de bacia (3), e nos dois dígitos subseqüentes numeração seqüencial.

Para facilitar a identificação dos resultados deste trabalho e permitir a comparação com dados da SABESP em estudos futuros, optou-se pela utilização dos mesmos códigos de ponto de coleta adotados pela referida companhia. 
Os parâmetros de interesse para este estudo foram pré-estabelecidos embora existirem lacunas e a escolha destes ocorreu frente a significância sanitária e a possibilidade de serem localizados nos bancos de dados, são eles: coliformes totais, coliformes fecais, fitoplâncton (UPA), clorofila-a, cor, turbidez, condutividade, transparência, $\mathrm{pH}$, temperatura, OD (oxigênio dissolvido), DBO (demanda bioquímica de oxigênio), DQO (demanda química de oxigênio), Sólidos totais, Sólidos dissolvidos, Sólidos em suspensão, Nitrogênio total, Nitrogênio amoniacal, Nitrogênio nitrito, Nitrogênio albuminóide, Nitratos, Fósforo total, Fósforo reativo+hidrol total, Fosfato total e Fosfato solúvel.

Em se tratando dos valores apresentados nas planilhas elaboradas deve-se esclarecer que os mesmos representam o resultado de cálculo da mediana dos registros disponíveis para cada parâmetro em cada ano referente ao ponto de coleta em questão. A decisão de se fazer uso do cálculo das medianas foi levada na tentativa de se eliminar valores discrepantes que poderiam comprometer a avaliação do comportamento dos parâmetros.

Ressalta-se que devido às lacunas de dados encontradas (lembrando que o trabalho da SABESP caracteriza-se como vigilância) decidiu-se exibir o número de mostras existentes e utilizadas no cálculo da mediana; essa informação está apresentada em uma coluna denominada " $\mathrm{N}$ " posicionada à esquerda do respectivo valor.

Outro fato a esclarecer refere-se à divisão sazonal dos registros disponíveis a cada ano. Por meio de consulta aos índices pluviométricos na Grande São Paulo (EMPLASA, 1997) foi definida a divisão sazonal em dois períodos durante o ano; sendo o primeiro chuvas - janeiro, fevereiro, março, outubro, novembro e dezembro, e o segundo estiagem - abril, maio, junho, julho, agosto e setembro (ver planilhas de dados - Anexo). 


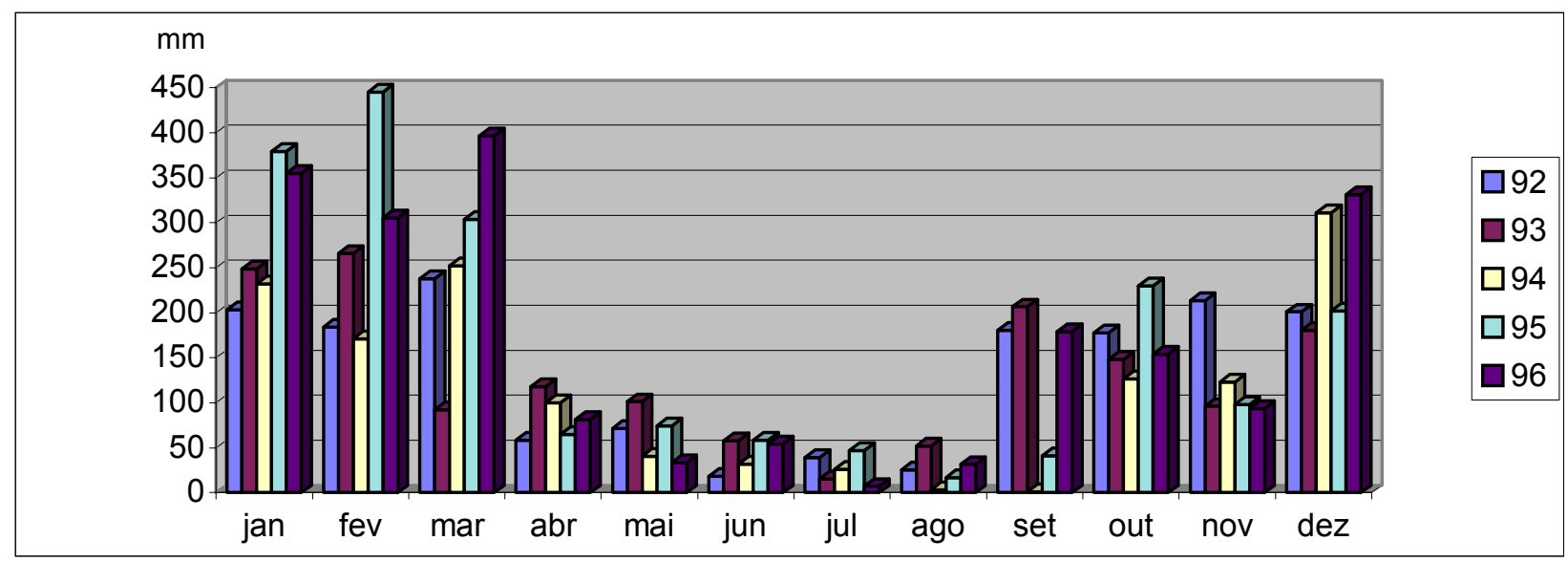

Gráfico 1: Evolução da Precipitação Pluviométrica - Mensal - 1992/1996 - São Paulo - SP

Fonte: Instituto Nacional de Meteorologia (VII Distrito) apud Emplasa, 1997

A mesma forma de segregação de dados foi aplicada àqueles disponíveis do ponto de coleta da CETESB, e então, elaborada planilha pertinente, buscando os valores para as mesmas variáveis escolhidas para os dados da SABESP. No entanto, alguns dos parâmetros pré-estabelecidos também não possuíam representação entre os relatórios da CETESB, acarretando novamente grande número de lacunas na planilha (ver planilha da CETESB em Anexo).

Posteriormente a este processo de segregação e composição das planilhas, decidiu-se pela confecção de gráficos que permitissem uma melhor visualização dos dados para facilitar o processo de análise dos mesmos. Para tanto, a maneira escolhida para a representação gráfica, foi de demonstração de variações temporais de valores. Estes gráficos foram elaborados para cada ponto de coleta.

Para as planilhas constituídas de dados da SABESP, diante dos parâmetros com valores disponíveis, foi possível compor seis gráficos de variação temporal para cada planilha, sendo os mesmos elaborados na tentativa de associar parâmetros similares, são eles (gráficos 1 a 60 - Anexo):

- Coliformes totais e Coliformes fecais; 
- Nitrogênio amoniacal, Nitrito, Nitrato e Nitrogênio total;

- Fosfato total e Fósforo total;

- DQO;

- $\quad$ Cor e Turbidez;

- Condutividade e Sólidos em suspensão.

No caso da planilha constituída de dados da CETESB, também foi possível compor seis gráficos de variação temporal, porém, estes apresentaram diferenças em sua composição em virtude dos parâmetros com valores disponíveis, são eles (ver gráficos 61 a 66):

- Coliformes totais e Coliformes Fecais;

- Nitrogênio amoniacal, Nitrito, Nitrato e Nitrogênio total:

- Fósforo total

- OD, DBO e DQO;

- Turbidez;

- Condutividade e Temperatura da água.

Pelo fato destes gráficos não permitirem associação do comportamento dos valores entre os pontos, optou-se pela elaboração de outros gráficos que pudessem demonstrar as variações espaciais dos valores. Para isso, foi necessário selecionar apenas os pontos da SABESP que representassem o curso deste manancial desde o desemboque do túnel que traz a água dos reservatórios à montante de Paiva Castro até a captação da Elevatória Santa Inês e então, realizar o cálculo de mediana dos valores de parâmetros escolhidos, resultando em valores de medianas correspondentes ao período de 1987 - 1998 para cada parâmetro escolhido em cada ponto de coleta pertinente.

Os pontos de coleta da SABESP selecionados para a elaboração dos gráficos de variação espacial foram: PC-301, PC-215, PC-104, PC-103, PC-102 e PC-002. E os gráfícos elaborados com associação de parâmetros foram: 
- Coliformes totais e Coliformes fecais (ver gráfico 67);

- Nitrogênio amoniacal, Nitrito, Nitrato e Nitrogênio total (ver gráfico 68);

- Fosfato total e Fósforo total (ver gráfico 69);

- DQO (ver gráfico 70);

- $\quad$ Cor e Turbidez (ver gráfico 71);

- Condutividade e Sólidos em suspensão(ver gráfico 72).

Em posse destes instrumentos foi possível analisar os dados de modo a fazer inferências sobre o comportamento dos parâmetros de qualidade de água no reservatório com relação às principais fontes poluidoras pontuais. 


\section{DISCUSSÃ̃}

Após a elaboração dos gráficos de análise temporal e espacial, utilizados para analisar as variações ocorridas no reservatório, os parâmetros que possuíam registros representativos foram incluídos na discussão efetuada neste capítulo com a finalidade de embasar os comentários pertinentes à qualidade da água na bacia do reservatório Paiva Castro.

Sob o ponto de vista da contaminação das águas naturais por esgotos domésticos, grande importância possui a análise microbiológica, sobretudo os níveis de coliformes totais e fecais, que determinam indiretamente a possibilidade da presença de organismos nocivos à saúde humana. Especialmente, deve-se verificar a ocorrência da espécie Escherichia coli, característica da presença das fezes humanas - de animais homeotermos ou de "sangue quente" - indicando a provável existência de microrganismos intestinais patogênicos como bactérias, vírus, protozoários e vermes, geralmente associados (BRANCO, 1986).

Com referência à turbidez da água, este parâmetro consiste do grau de redução de intensidade que um feixe de luz sofre ao atravessá-la, que ocorre devido à presença de sólidos em suspensão, outro parâmetro analisado, que se refere à partículas de diâmetro maior ou igual a 1,2 $\mu \mathrm{m}$, correspondente a frações inorgânicas (areia, silte, argila) e/ou detritos orgânicos do plâncton em geral (PIVELI, 2000).

No caso da cor, considerando que seus níveis relacionam-se com a presença de sólidos dissolvidos, principalmente material em estado coloidal orgânico e inorgânico (PIVELI, 1998), nesse estudo espera-se relacionar a variação desse parâmetro em proporção direta com os lançamentos de esgotos domésticos e com a presença de matéria orgânica de origem algal.

Os parâmetros cor e turbidez assumem grande importância no processo de tratamento de água, estando seus níveis associados aos processos de coagulação e floculação. Ressalta-se que águas naturais com teores elevados de cor e baixa turbidez consistem problemas nesta fase do tratamento pela ausência de partículas maiores que sirvam como 
núcleo para os flocos. Para resolver este problema é usual a aplicação de cloro (pré-cloração) na etapa de coagulação e floculação, oxidando a matéria orgânica responsável pelo excesso de cor. No entanto, esta prática está diretamente associada ao processo de formação dos trihalometanos (PIVELI, 2000).

A DBO (Demanda Bioquímica de Oxigênio) é um parâmetro fundamental para o controle da poluição das águas por matéria orgânica, consiste na determinação da fração biodegradável dos compostos presentes em uma amostra que é mantida durante 5 dias a uma temperatura de $20{ }^{\circ} \mathrm{C}$ (PIVELI, 2000). Porém, lamentavelmente, não há registros suficientes de tal parâmetro no banco de dados da SABESP (1999), ocorrendo registros satisfatórios apenas nas planilhas da CETESB (1998).

A SABESP adotou apenas a análise da DQO (Demanda Química de Oxigênio) como constante em suas análises. A determinação deste parâmetro consiste do emprego do dicromato de potássio, forte oxidante químico, capaz de oxidar um número maior de compostos do que na reação bioquímica, em razão disso, os valores de DQO são superiores aos de DBO (PIVELI, 2000). Diante da impossibilidade de determinar a fração orgânica biodegradável correspondente aos esgotos domésticos nos resultados de DQO, restou a possibilidade de apenas relatar os índices mais elevados de tal parâmetro, ou mesmo, de verificar tendências em seu comportamento por variações temporais ou espaciais.

O nitrogênio como fator limitante à produção primária pode servir à classificação do nível trófico de um corpo d'água segundo os teores desse elemento, conforme a classificação de VOLLENWEIDER (1968, apud ESTEVES, 1998).Ver tabela 1.

Em geral, a principal fonte de nitrogênio nas águas naturais provém do lançamento dos esgotos sanitários, além de lançamentos industriais, cargas difusas da fertilização agrícola e origem atmosférica por fixação biológica, fixação química ou carreamento de partículas da atmosfera pela chuva. O nitrogênio orgânico constitui parte integrante da matéria orgânica, o processo de sua oxidação é conhecido como nitrificação e ocorre pela ação das bactérias nitrificantes (PIVELI, 1998). A presença de nitrogênio amoniacal e de nitritos - forma mais reduzida - nas águas está associada ao lançamento recente das cargas poluidoras, (BRANCO, 1986). Os nitritos são encontrados em baixas 
concentrações em ambientes aeróbios e representam fase intermediária entre a amônia e o nitrato - forma mais oxidada. O nitrato e o íon amônio apresentam grande importância para os ecossitemas aquáticos por serem as principais fontes de nitrogênio para os produtores primários (ESTEVES, 1998).

No entanto, o fósforo é o principal fator limitante da produtividade na maioria das águas continentais. Todo o fósforo presente nas águas encontra-se sob a forma de fosfato, sendo assim, utiliza-se esta denominação para a ocorrência de fósforo em ambientes aquáticos (ESTEVES, 1998). Em águas naturais sua concentração é bastante reduzida e seu aporte está ligado especialmente aos despejos domésticos, de esgotos e de detergentes de uso domiciliar (BRANCO, 1986). O corpo d'água também pode ser classificado, em seu estado trófico, em função da concentração de fósforo (PIVELI, 2000). Ver tabela 2.

Tabela 1: Classificação de lagos e reservatórios quanto ao nível trófico segundo compostos nitrogenados (VOLLENWEIDER, 1968 apud ESTEVES, 1998)

\begin{tabular}{cccc}
\hline Nível Trófico & $\begin{array}{c}\text { Nitrogênio } \\
\text { amoniacal } \mathrm{mg} / \mathrm{L}\end{array}$ & Nitrato $\mathrm{mg} / \mathrm{L}^{-1}$ & Nitrito $\mathrm{mg} / \mathrm{L}$ \\
\hline Oligotrófico & $0,0-0,3$ & $0,0-1,0$ & $0,0-0,5$ \\
Mesotrófico & $0,3-2,0$ & $1,0-5,0$ & $0,5-5,0$ \\
Eutrófico & $2,0-15,0$ & $5,0-50,0$ & $5,0-15,0$ \\
\hline
\end{tabular}

Tabela 2: Classificação de lagos e reservatórios quanto ao nível trófico segundo concentrações de fósforo total e clorofila (PIVELI, 2000).

\begin{tabular}{ccc}
\hline Nível Trófico & Fósforo total $\mathrm{mg} / \mathrm{L}$ & Clorofila $\mu \mathrm{g} / \mathrm{L}$ \\
\hline Oligotrófico & $<0,010$ & $<2,5$ \\
Mesotrófico & $0,010-0,035$ & $2,5-8,0$ \\
Eutrófico & $0,035-0,100$ & $8,0-25,0$ \\
Hipereutrófico & $>0,100$ & $>25$ \\
\hline
\end{tabular}


Cabe aqui justificar sobre dois parâmetros com dados disponíveis que não foram utilizados em análises por não apresentarem registros suficientes, são eles: fitoplâncton e clorofila_a, sendo que o último além de não possuir número satisfatório de registros, nenhum dos valores obtidos em mediana ultrapassou níveis expressivos que pudessem caracterizar o reservatório como eutrófico.

Também é possível proceder a uma análise comparativa dos valores de parâmetros de qualidade de água apresentados nesta dissertação com os valores estabelecidos pelas legislações vigentes que classificam os corpos d'água, conferindo padrões de qualidade para os mesmos.

O Estado de São Paulo teve a iniciativa de legislar em prol da questão ambiental e através da lei $\mathrm{n}^{\mathrm{o}} 997$ e do seu decreto regulamentador, $\mathrm{n}^{\mathrm{o}}$ 8468, ambos de 1976, classificou os corpos d'água segundo os seus usos preponderantes variando de classe 1 (mais nobre) à classe 4 (menos nobre), estabelecendo padrões de qualidade para estes corpos d'água e também padrões de emissões de efluentes nos mesmos. Em 1986 foi publicada a Resolução $\mathrm{n}^{\mathrm{o}} 20$ do Conselho Nacional do Meio Ambiente - CONAMA, que estabeleceu uma nova classificação para os corpos d'água do Território Nacional (CETESB, 1999).

De acordo com CETESB (1997) "o reservatório Paiva Castro, enquadrado na Classe Especial, deve obedecer aos padrões da Classe 1 da Resolução CONAMA 20/86 ou da Classe 2 do Decreto Estadual no $8468 "$.

Seguindo essa determinação foram escolhidos os mesmos padrões comparativos de referência de qualidade da água utilizados pela CETESB, assim, tomamos como base os valores apresentados na planilha de dados do Relatório de Qualidade das Águas Interiores do Estado de São Paulo, que hora utilizam de padrões de qualidade da resolução CONAMA 20/86, hora utilizam padrões da legislação estadual - decreto 8468/76, conforme o mais restritivo (CETESB, 1997). 
Dentre os parâmetros selecionados nesta dissertação, seguem aqueles que apresentam os respectivos valores limite:

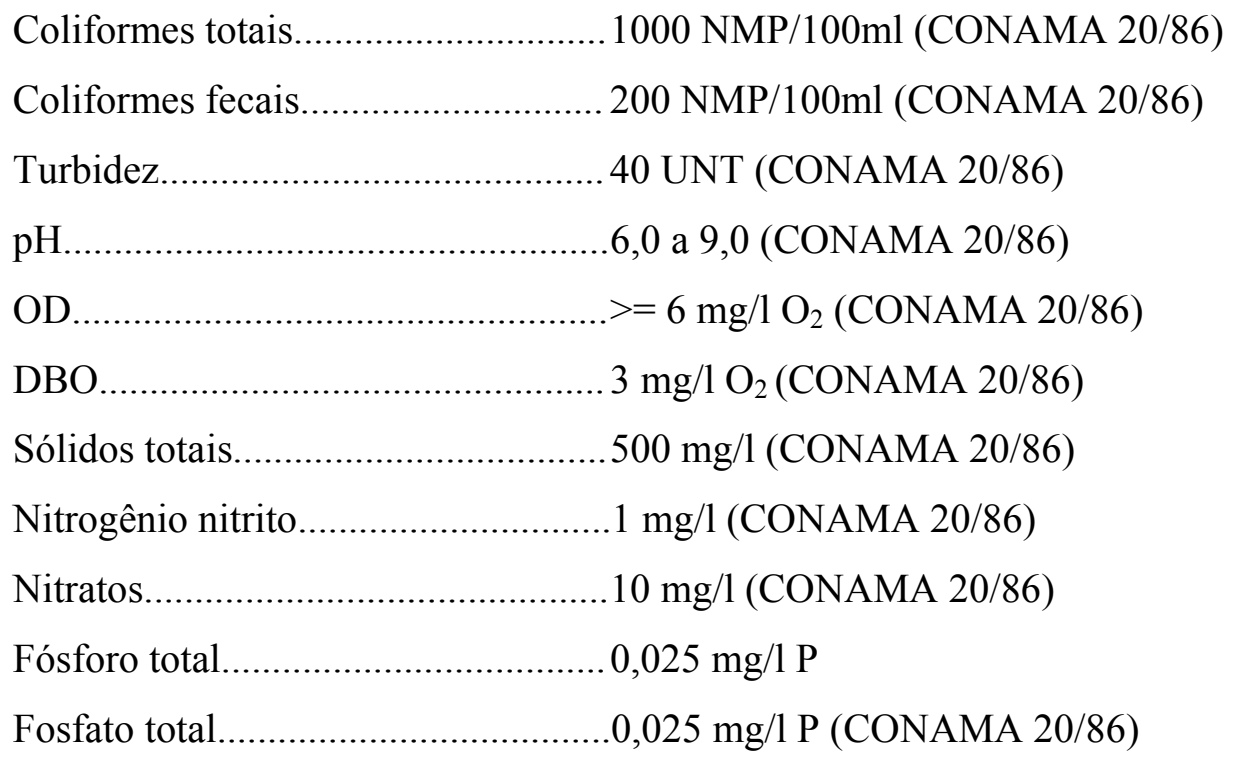

\subsection{ANÁLISE TEMPORAL}

Com relação à seqüência de transposição das águas no Sistema Cantareira, há de se considerar que as águas dos demais reservatórios adentram a bacia do Rio Juquerí onde são misturadas com suas vazões, sofrendo os impactos das cargas poluidoras do município de Mairiporã. Verificando que tal deságue ocorre através da saída do túnel 5, onde localiza-se PC-301 (foto 7), torna-se justificável a escolha desse ponto de coleta como demonstrativo da qualidade da água à montante.

No tocante aos coliformes totais PC-301 demonstrou níveis aceitáveis, exceto por um pico na estiagem de 1993 e outro nas chuvas em 1997, verifica-se ainda, uma elevação nos valores de 1996-98, que no entanto, estiveram abaixo dos valores exigidos pela legislação. Quanto aos coliformes fecais nesse ponto os níveis registrados foram baixos exceto por um único pico na estiagem de 1991 (ver Anexo - gráfico 1) . 


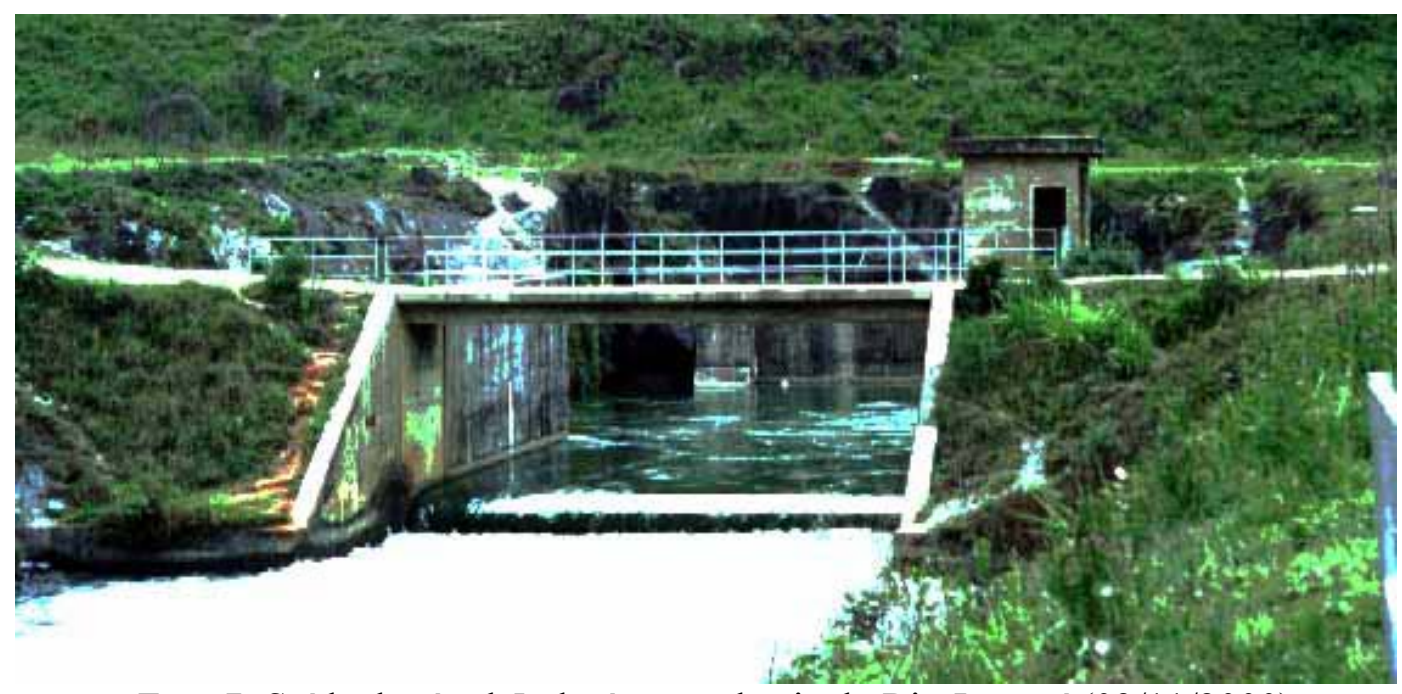

Foto 7: Saída do túnel 5, deságüe na bacia do Rio Juquerí (03/11/2000).

A série Nitrogênio não apresentou nenhuma tendência em PC-301, mantendose sob ligeiras variações com valores aceitáveis, a única ocorrência a relatar foi um pico de Nitrogênio Total e de Nitrogênio Amoniacal na estiagem de 1992, que mesmo assim, não ultrapassou os limites vigentes (ver Anexo - gráfico 2).

Fósforo total e Fosfato total estiveram em níveis satisfatórios em PC-301, porém em 1997 registrou-se um pico, onde Fosfato total em estiagem e anual, além de Fósforo total em estiagem registraram valores acima do permitido (ver Anexo - gráfico 3).

Ainda em PC-301 a DQO demonstrou picos em 89 estiagem e 98 anual e chuvas (ver Anexo - gráfico 4). Cor apontou pico em 97 anual e chuva, atingindo a marca de 15 UC (ver Anexo - gráfico 5). E ainda, Sólidos em Suspensão apresentaram mais elevados em 88 chuvas e 90 estiagem (ver Anexo - gráfico 6).

O início do estudo da qualidade da água na bacia do Rio Juquerí, ocorre em PC-210, primeiro ponto de coleta da SABESP nesse rio, local sob influência direta da Vila Ponte Alta (fotos 8 e 9), de onde os esgotos domésticos são lançados diretamente no manancial. 
Os parâmetros de coliformes totais e fecais em PC-210 apresentam-se em total desconformidade com os limites estabelecidos por lei, apesar da ausência de dados de 199495, pode-se verificar elevações em 1991 estiagem, 1992 chuva estiagem, 1993 anual, chuva e estiagem, 1996 estiagem e 1997 chuva (ver Anexo - gráfico 7).

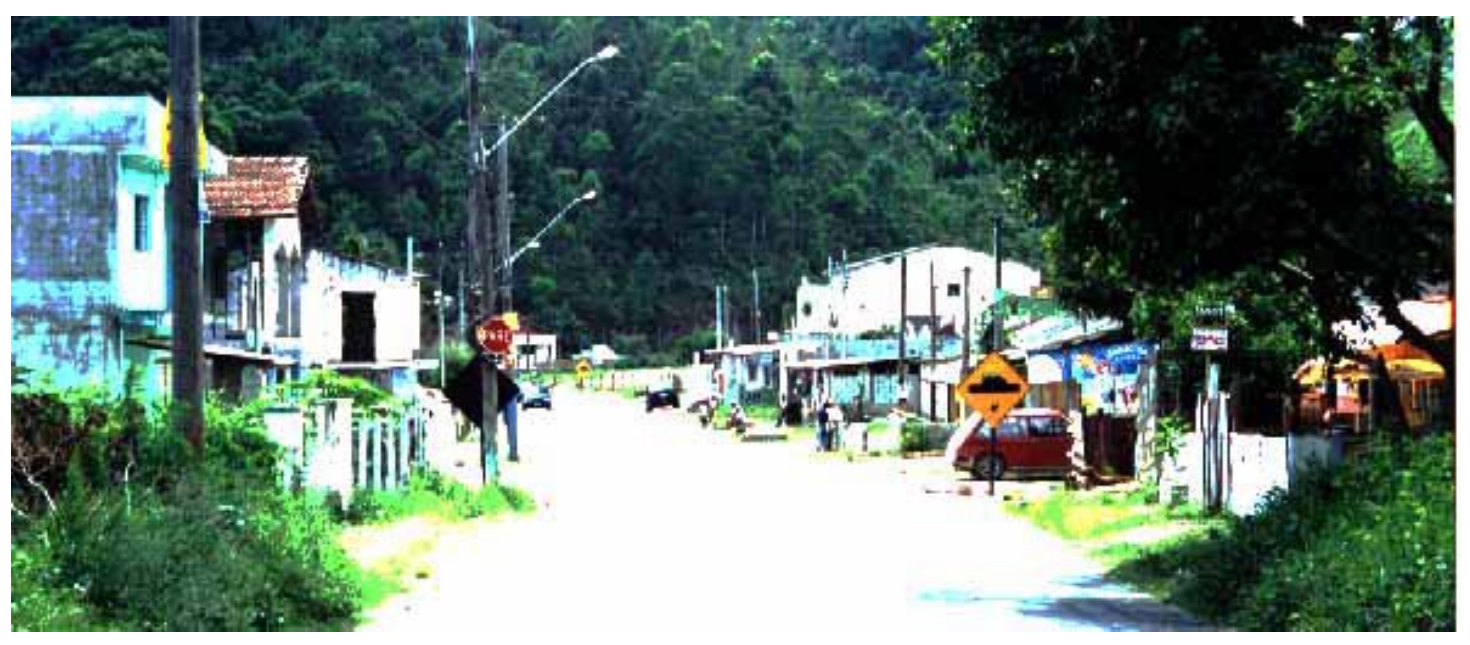

Foto 8: Vila Ponte Alta na estrada que liga Mairiporã à Nazaré Paulista (03/11/2000).

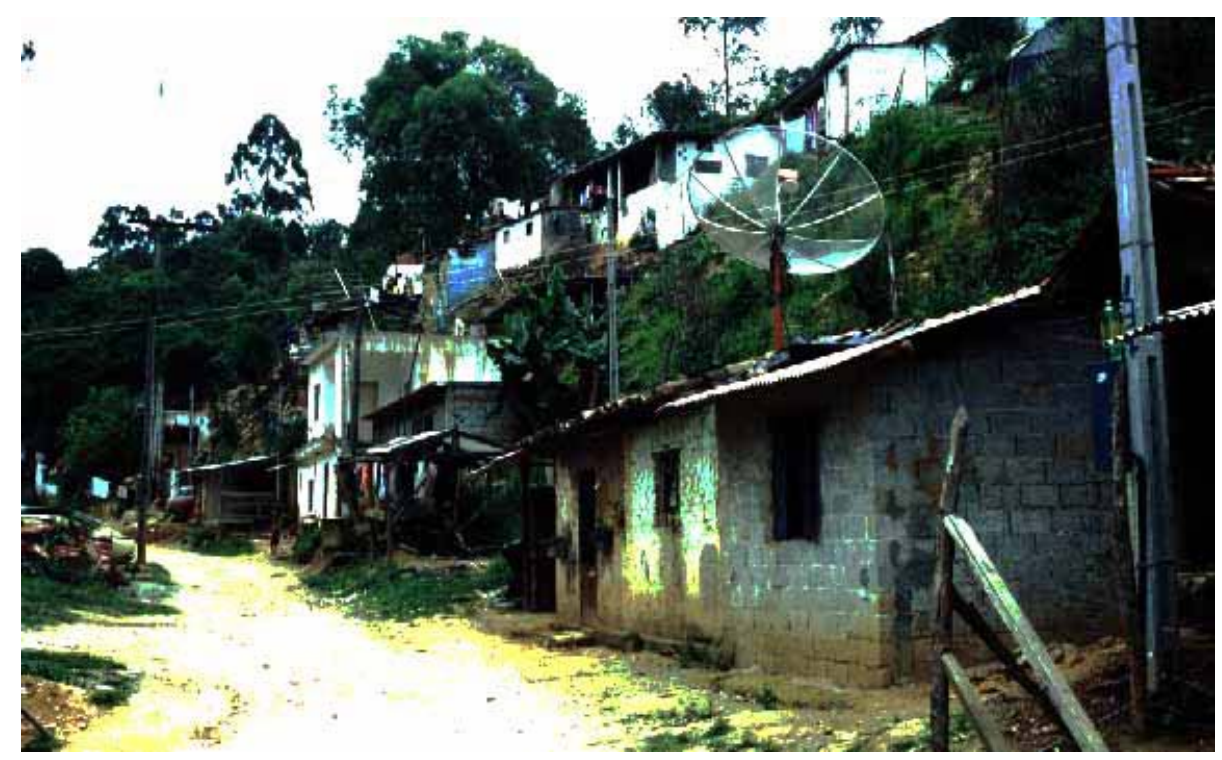

Foto 9: Loteamento irregular recente na Vila Ponte Alta (03/11/2000). 
Nitrogênio total apresentou tendência ligeiramente crescente de 1993-1998, enquanto Nitrato também demonstrou ligeiro crescimento de 1992-98, porém esses dois parâmetros estiveram em acordo com a legislação em PC-210 (ver Anexo - gráfico 8).

Fosfato total registrou níveis inaceitáveis na maioria dos registros, sobretudo entre 1990-95. Enquanto que Fósforo total ultrapassou os limites principalmente entre 199093 e posteriormente em 1996 anual e chuva, 1997 estiagem e 1998 (ver Anexo - gráfico 9).

Continuando em PC-210, DQO não apresentou tendência definida, no entanto, ocorreram valores elevados em 1989-91, 1994 e 1997-98 (ver Anexo - gráfico 10). A Cor chegou atingir valores altos, destacando-se 1989 chuva (80 UC) e 1991 estiagem (85 UC), enquanto turbidez só demonstrou um pico em 1998 (ver Anexo - gráfico 11). A condutividade apresentou valores relativamente estáveis entre 30 e 40 umnho/cm e os Sólidos em Suspensão demonstraram um pico em 1991 estiagem e 1997 chuva (ver Anexo - gráfico 12).

O ponto de coleta PC-212 corresponde ao Rio Pinheiros, que apresenta importância sanitária pelo fato de estar recebendo contribuições domésticas brutas em sua bacia, incluindo o bairro Pirucaia situado na Serra da Cantareira à sua montante. No entanto, sua bacia de drenagem possui alguns lagos, os quais recebem esgotos domésticos sem tratamento do Jardim Celeste (foto 10) e Jardim Espada e funcionam como lagoas de estabilização de esgotos. 


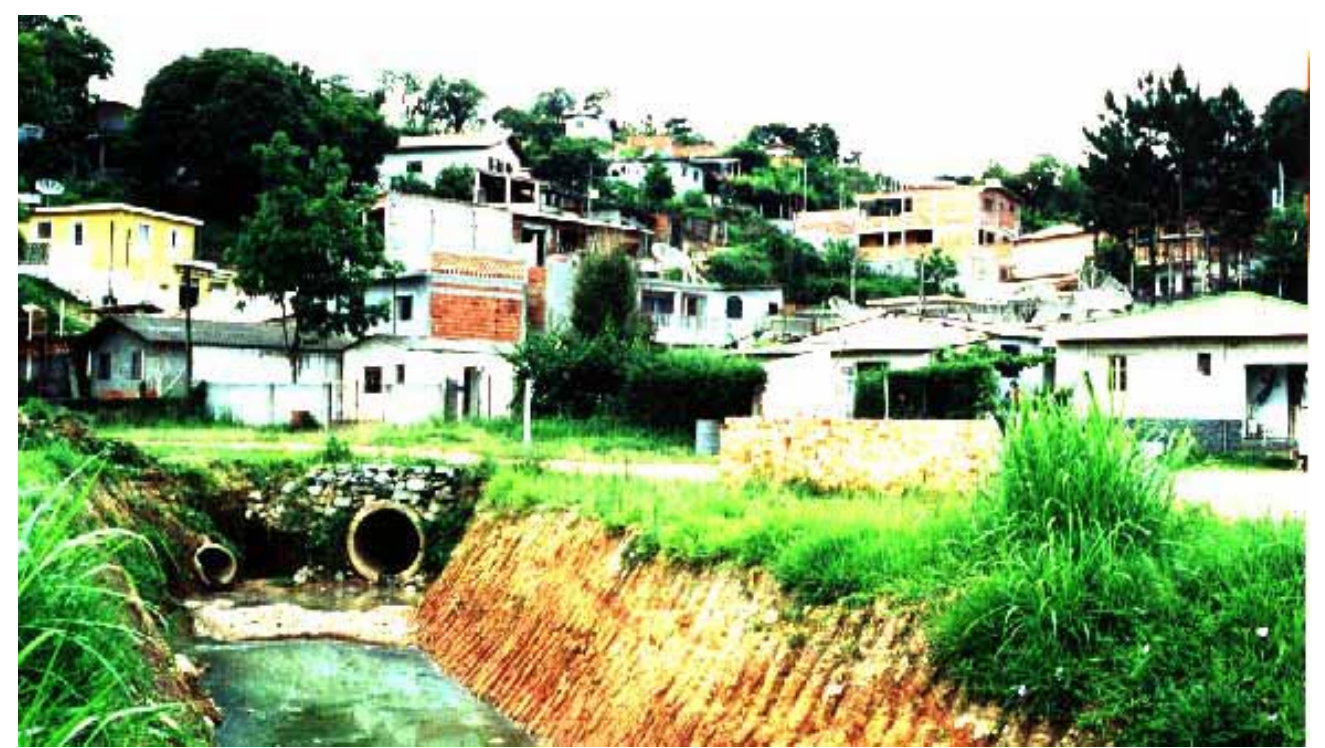

Foto 10: Galerias de águas pluviais trazendo esgotos domésticos do jardim celeste para o manancial $(03 / 11 / 2000)$.

Os coliformes totais e fecais nesse ponto apresentaram total desconformidade com a legislação, demonstrando grande elevação em 1993 (ver Anexo - gráfico 13). Nitrato apresentou valores mais elevados a partir de 1991 (ver Anexo - gráfico 14), enquanto fósforo total e fosfato total não permitiram verificar nenhuma tendência, a não ser algumas elevações como de fósforo total em 1994 estiagem (ver Anexo - gráfico 15).

Continuando o estudo em PC-212, verificou-se DQO com valores elevados constrantes em 1990 e mais elevados em 1997-98 (ver Anexo - gráfico 16). Cor apresentou elevações em 1988 chuva, 1989 chuva, 1990 chuva e pico em 1991 chuva, enquanto turbidez registra alta em 1998 (ver Anexo - gráfico ). Sólidos em suspensão, apesar da ausência de dados, demonstrou pico em 1991 (ver Anexo - gráfico 18). 
De grande importância nesta dissertação, o ponto de coleta PC-214, no Ribeirão Itaim, é capaz de refletir o lançamento de esgotos de diversos bairros com saneamento precário à montante, incluindo o Parque Náutico (fotos 11 e 12). Contudo, o maior valor sanitário deste ponto consiste no seu posicionamento à jusante do lançamento do efluente da estação de tratamento de esgotos de Mairiporã e também próximo do Canal do Rio Juquerí, podendo assim, demonstrar o aporte de cargas poluidoras no manancial.

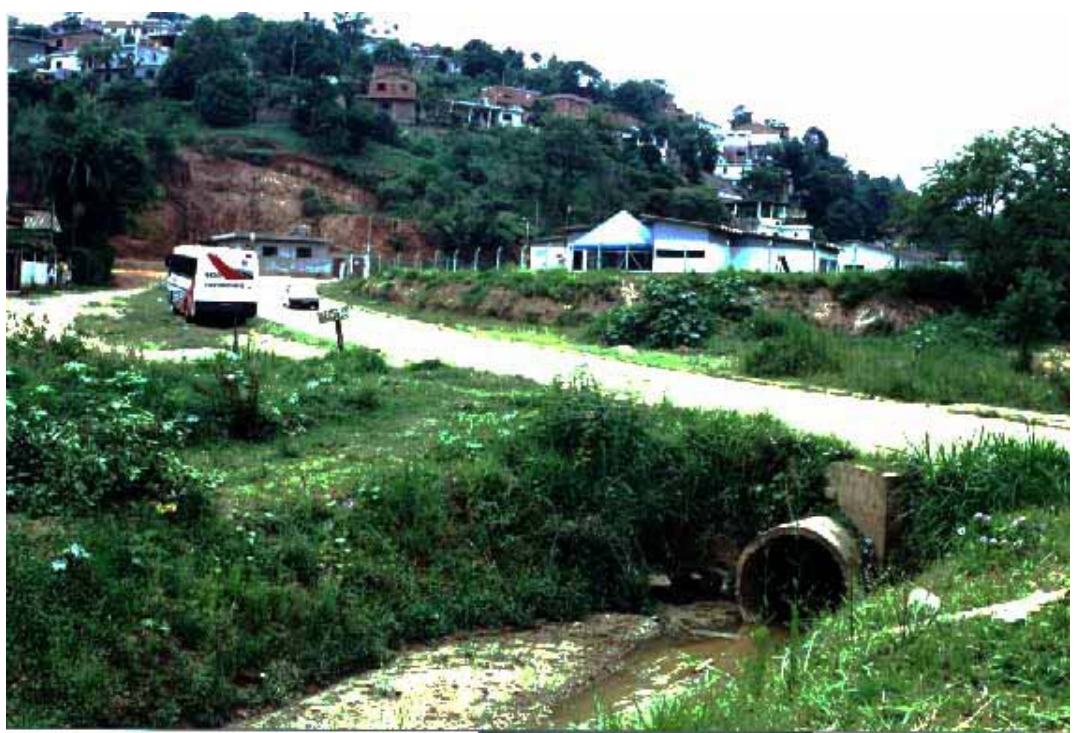

Foto 11: Ribeirão Itaim recebendo esgotos domésticos do Parque Náutico (03/11/2000)

Verificando que o Ribeirão Itaim apresenta baixas vazões, este demonstra ser severamente afetado pelo aporte das cargas poluidoras. Tanto coliformes totais e fecais (ver Anexo - gráfico 19) como fósforo total e fosfato total (ver Anexo - gráfico 21), demonstraram valores muito elevados e em desconformidade com a legislação. Vale destacar que os valores de Nitrogênio amoniacal são bem superiores aos de nitrato, indicando poluição recente e proximidade com a fonte poluidora (ver Anexo - gráfico 20).

Os valores de DQO registrados em PC-214 também foram bastante elevados com pico em 1991 (ver Anexo - gráfico 22). Cor também registrou valores muito altos com grande elevação em 1997, enquanto turbidez teve elevações em 1992 chuva, 1993 chuva e maiores picos em 1997 chuva e 1998 chuva (ver Anexo - gráfico 23). Acompanhando os 
demais parâmetros, verifica-se altos valores de condutividade e sólidos em suspensão, sendo que o último demonstra maiores elevações em 1994 chuva e 1997 chuva (ver Anexo - gráfíco 24).

Novamente no Rio Juquerí, tem-se o ponto de coleta PC-215, à montante e próximo da "cauda" do reservatório. Nesse local, podemos constatar a mistura das águas dos demais pontos à montante e então, podemos verificar o impacto de fortes contribuições orgânicas da bacia do Rio Juquerí sob as águas dos demais reservatórios.

Outro fator importante é que este ponto marca uma área de transição de ambiente lótico para lêntico. Sendo assim, demonstra a qualidade das águas que adentram o reservatório.

Aqui se pode observar que coliformes totais e fecais extrapolam os níveis determinados pela legislação em todos os registros, além das grandes variações destes dois parâmetros, é possível verificar que coliformes totais apresentam níveis muito mais elevados em 1987 anual e chuva, 1988 chuva, 1989 chuva e 1993 (ver Anexo - gráfico 25).

É possível notar que nesse ponto nitrato apresenta elevação dos valores em 1995-97 e ainda, nitrogênio amoniacal demonstra valores superiores aos de nitrato, demonstrando a proximidade com fontes poluidoras (ver Anexo - gráfico 26).

Em PC-215, fosfato total aponta valores mais elevados em 1987 anual e chuva, 1988 estiagem, 1989 chuva e 1991 estiagem, fósforo total não demonstrou elevações marcantes, no entanto, esses dois parâmetros apresentaram ocasionais ultrapassagens do limite estabelecido por legislação (ver Anexo - gráfico 27).

A DQO esveve elevada na maior parte dos registros, porém, seus maiores valores ocorreram em 1994-1995 e 1997-98 (ver Anexo - gráfico 28). Cor apresentou elevação em 1988 chuva e 1989 chuva, com pico em 1991 estiagem, enquanto turbidez registrou maiores altas em 1991 estiagem e 1997 chuva e 1998 chuva (ver Anexo - gráfico 29). Condutividade apontou um único valor inconstante, que foi um pico em 1987 estiagem, quanto a Sólidos em suspensão é possível observar elevações em 1987 chuva, 1989 estiagem, 1991 estiagem e 1994 chuva (ver Anexo - gráfico 30). 
Já no corpo do reservatório, o ponto de coleta PC-104 está sob influência de novas contribuições advindas da área de urbanização mais intensa do município de Mairiporã, os lançamentos de esgotos ocorrem em função do não atendimento de todas as residências da cidade pela rede coletora, além de que, uma concentração urbana do lado da margem direita do reservatório compreende os bairros: Vila Santa Cruz, Chácara Arantes e Jardim Socimar (foto 12), os quais apontam precariedades na rede de esgotamento sanitário e inexistência de tratamento de esgotos, ou seja, as cargas poluidoras correm em direção ao manancial.

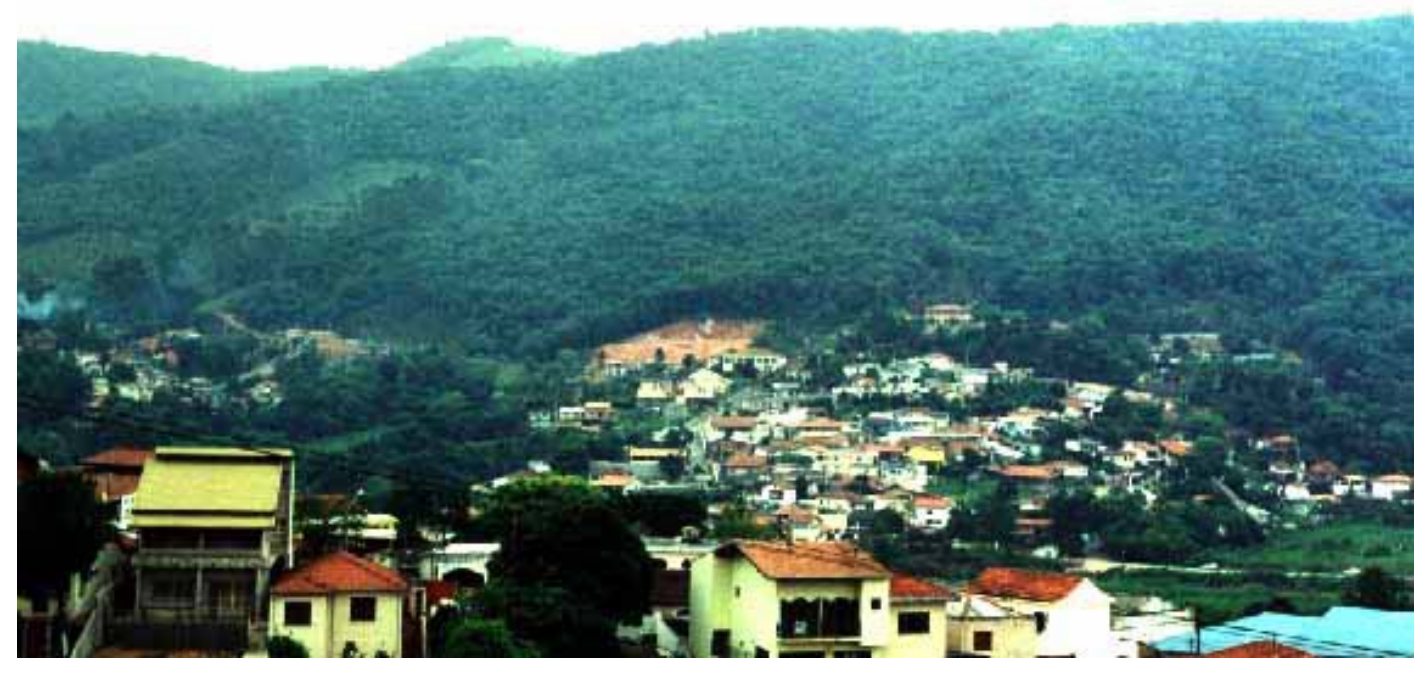

Foto 12: Ao fundo os bairros da margem direita do reservatório Paiva Castro (03/11/2000).

Apesar da ausência de registros de coliformes até o ano de 1994, os níveis observados à partir de 1995 demonstram valores superiores ao determinado por legislação, com um pico muito elevado de coliformes totais em 1998, enquanto coliformes fecais apontam níveis elevados em 1996 anual e chuva (ver Anexo - gráfico 31).

A série nitrogênio apresenta valores inconstantes, sendo que novamente aqui nesse ponto parece haver proximidade com lançamentos de cargas poluidoras, este evento 
pode ser verificado pelo fato dos valores de nitrogênio amoniacal estarem próximos e às vezes superiores aos de nitrato (ver Anexo - gráfico 32).

Em PC-104, os níveis de fosfato total e de fósforo total só apresentam registros à partir de 1992, sendo que eventualmente seus valores extrapolam os valores máximos permitidos por legislação (ver Anexo - gráfico 33). Valores altos de DQO são registrados aqui, sendo os maiores picos em 1995 chuva, 1996 anual e 1998 chuva (ver Anexo - gráfico 34). Para cor e turbidez, este ponto só possui registros em 1994 e 1997 ambos em estiagem, porém, sem demonstrar níveis muito elevados (ver Anexo - gráfico 35). Condutividade só apresenta valores em 1991 e 1992, ambos em chuva e não elevados, enquanto ocorre apenas um registro de sólidos em suspensão, o qual não possui valor elevado (ver Anexo - gráfico 36).

O Bairro conhecido como Barreiro e o Jardim Capri (foto 13), são extensões da cidade de Mairiporã, no entanto, estão compreendidos na bacia de drenagem do Ribeirão Barreiro, fora do alcance da drenagem dos esgotos para a estação de tratamento do município. $\mathrm{Na}$ estrada do Barreiro pode-se verificar esgotos correndo a céu aberto em direção ao manancial (foto 14). O ponto de coleta PC-217A fica nesse ribeirão nas proximidades de sua confluência com o reservatório Paiva Castro, portanto, tal ponto pode indicar os efeitos dos lançamentos de esgotos domésticos através deste afluente.

Esse ponto de coleta só apresenta dados registrados pela SABESP nos anos de 1994-96. Observa-se nesse intervalo que não se realizou análise microbiológica das amostras, impossibilitando verificar dados de coliformes totais e fecais. Com relação à série nitrogênio, demonstra valores inconstantes, contudo, é possível notar que nitrogênio amoniacal apresenta valores próximos e superiores a nitrato, também aqui, dando indícios de poluição recente no corpo d'água (ver Anexo - gráfico 38). 


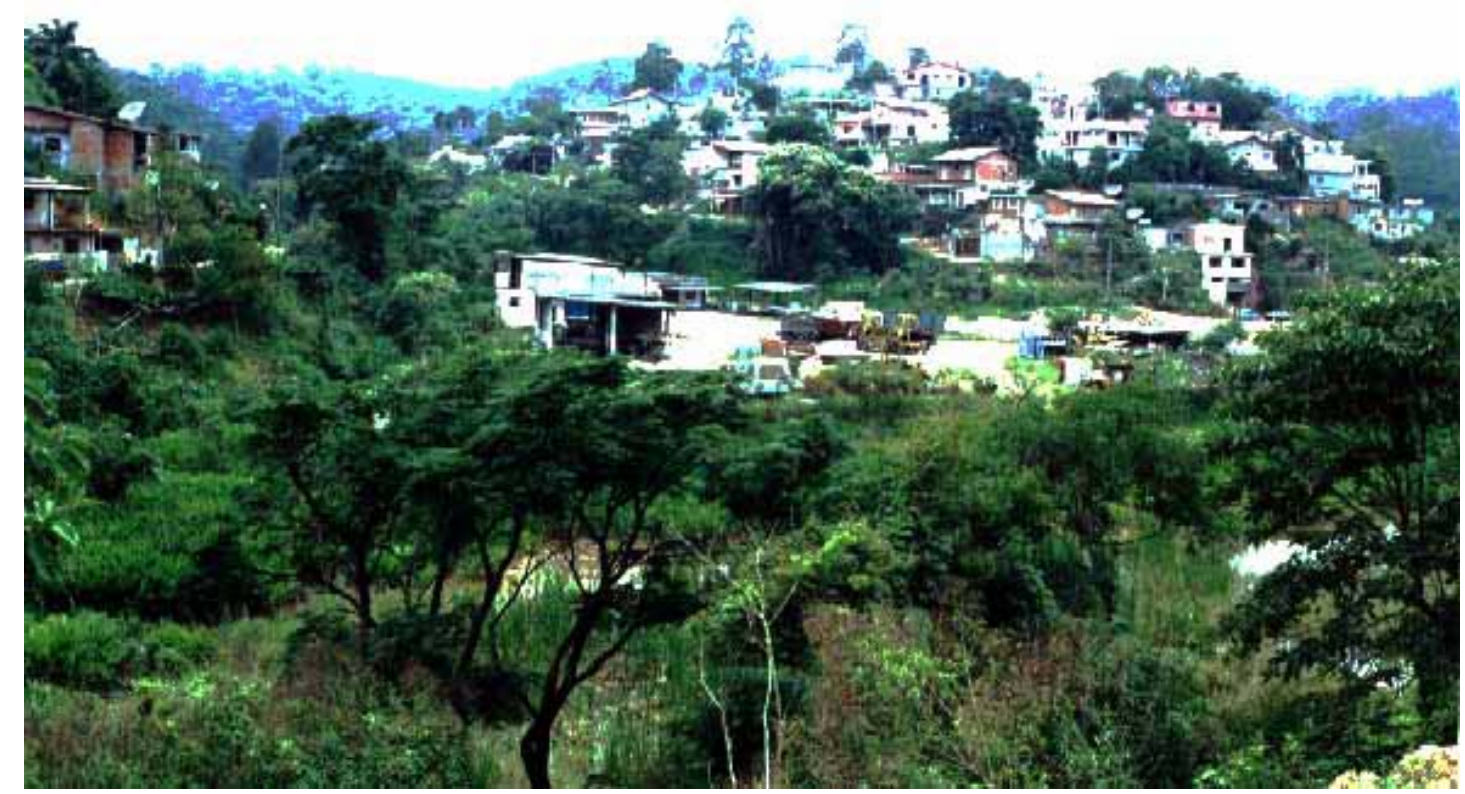

Foto 13: Jardim Capri situado na bacia do Ribeirão Barreiro (03/11/2000).

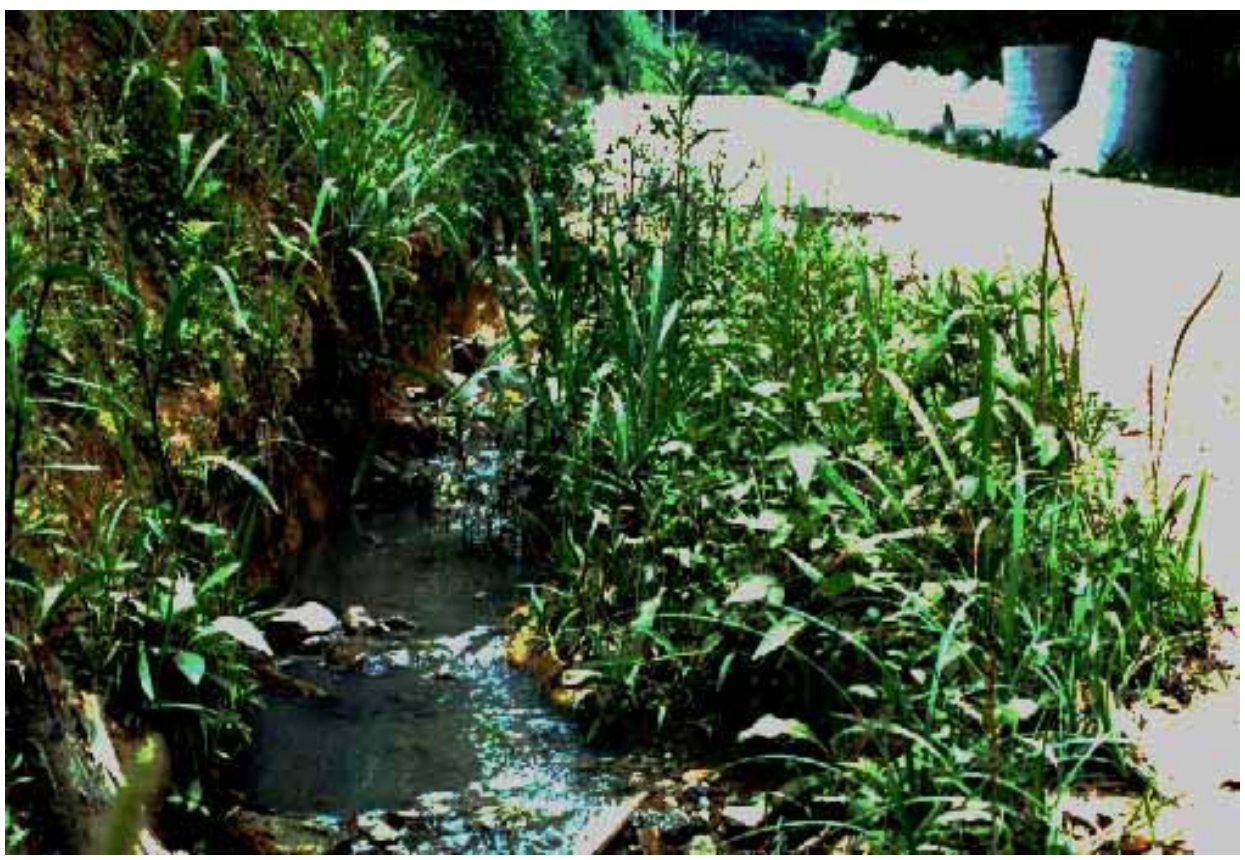

Foto 14: Esgotos correndo a céu aberto na Estrada do Barreiro em direção ao manancial $(03 / 11 / 2000)$. 
Em PC-217A fosfato total e fósforo total apresentaram valores elevados, sobretudo em 1995 e 1996 (ver Anexo - gráfico 39). DQO também demonstrou valores elevados e inconstantes (ver Anexo - gráfico 40), enquanto turbidez não apresentou registro, porém, cor apontou valores altos e pico muito elevado em 1995 (ver Anexo - gráfico 41). Sólidos em suspensão também não foi registrado, mas condutividade sim, apresentando valores altos e constantes (ver Anexo - gráfico 42).

De volta ao corpo do reservatório temos PC-103, área que provavelmente sofre influência da pluma de dispersão das cargas poluidoras lançadas a partir do Ribeirão Barreiro. Aqui, coliformes totais e fecais, registrados desde 1995, demonstram total inconformidade com os limites da legislação (ver Anexo - gráfico 43). A sério nitrogênio não apresentou valores muito elevados, nem mesmo alguma tendência clara (ver Anexo - gráfico 44). Fosfato total e Fósforo total apresentaram valores relativamente constantes, no entanto, algumas ultrapassagens dos limites de legislação estão registradas em 1992 chuva, 1993 chuva, 1994 chuva, 1995 anual, 1996 chuva e 1998 chuva (ver Anexo - gráfico 45).

Nesse ponto de coleta, DQO apresentou valores relativamente altos em alguns registros, principalmente em 1994 estiagem, 1995 chuva e 1998 chuva (ver Anexo - gráfico 46). Em se tratando de cor e turbidez, observa-se apenas dois registros de cada um desses parâmetros, não demonstrando valores elevados (ver Anexo - gráfico 47). Condutividade e sólidos em suspensão também registram pouquíssimos dados (ver Anexo - gráfico 48).

O ponto de coleta PC-102 é o último no corpo do reservatório, situa-se nas proximidades da Ponte Santa Inês, no braço do reservatório do mesmo nome. Há grande valia na análise de seus dados, tendo em vista a sua correspondência com o ponto de coleta da CETESB, situado na mesma área. Pela sua distância da área urbana do município, esse ponto já não está em área de influência direta de lançamentos de esgotos domésticos. Ocorre então, possibilidade de verificar a depuração das cargas orgânicas a partir desse ponto de coleta.

Os níveis de coliformes totais e fecais em PC-102, registrados desde 1995, não apresentaram valores satisfatórios, porém, estes não foram tão altos como os de PC-103 (ver Anexo - gráfico 49). A série nitrogênio não demonstra tendência definida e seus níveis não são elevados (ver Anexo - gráfico 50). Quanto a fosfato total e fósforo total os níveis 
estiveram aceitáveis, no entanto, em 1994 chuva, 1996 estiagem e 1997 estiagem, ocorreram níveis superiores aos permitidos pela legislação (ver Anexo - gráfico 51).

Ainda nesse ponto, nota-se DQO com valores mais elevados em 1991 chuva, 1993 anual e chuva, 1994 estiagem, 1995 chuva e 1996 estiagem (ver Anexo - gráfico 52). Para cor e turbidez, só existem dados em 1994 e 1997, nos quais não se verificam níveis elevados (ver Anexo - gráfico 53). Condutividade e sólidos em suspensão também apresentam poucos registros sem demonstrar níveis muito elevados (ver Anexo - gráfico 54).

Continuando nessa mesma área de amostragem, cabe aqui incluir os comentários pertinentes aos dados registrados no banco de dados da CETESB.

Nesse ponto os dados registrados pela CETESB, demonstram que coliformes totais apresentaram valores superiores aos limites da legislação na grande maioria dos registros, enquanto coliformes fecais extrapolaram esses limites ocasionalmente. Destacam-se valores mais elevados de coliformes totais em 1991 chuva, 1994 anual e estiagem, e maiores altas de coliformes fecais em 1990 chuva, 1995 chuva e 1996 chuva (ver Anexo - gráfico $61)$.

Ainda relatando dados da CETESB, temos a série nitrogênio sem apresentar tendências definidas, no entanto, um grande pico de nitrogênio total foi ocorreu em 1991 estiagem (ver Anexo - gráfico 62). Fósforo total esteve regularmente ultrapassando os limites da legislação com valor elevado em 1988 chuva e pico em 1995 estiagem (ver Anexo gráfico 63).

Os dados da CETESB permitiram verificar registros de OD que em sua maioria estiveram satisfatórios, acima dos valores mínimos determinados pela legislação. A DBO, em algumas ocasiões, esteve superior aos índices da legislação, destacando-se as maiores altas em 1989 estiagem, 1993 anual e estiagem. Com relação à DQO, este parâmetro apresentou valores mais elevados em 1987 anual e chuva e posteriormente uma alta constante em 1996-1998 (ver Anexo - gráfico 64).

A turbidez demonstrou valores elevados em 1995-96 e posteriormente em 1998 (ver Anexo - gráfico 65). A condutividade apresentou valores constantes nesse ponto. $\mathrm{O}$ monitoramento da CETESB inclui a temperatura da água como um de seus parâmetros, 
verifica-se então as variações: medianas anuais de 21,5 a $23,5{ }^{\circ} \mathrm{C}$; chuva de 23 a $26{ }^{\circ} \mathrm{C}$ e estiagem de 18 a $22{ }^{\circ} \mathrm{C}$ (ver Anexo - gráfico 66).

O teste de toxicidade é realizado pela CETESB neste reservatório desde 1993, este teste consiste da determinação do potencial tóxico de um agente químico ou de uma mistura complexa, verificada pela resposta de organismos vivos através de efeitos deletérios que são classificados como "efeito Agudo" - caracterizado por uma resposta severa e rápida a um estímulo, a qual se manifesta num intervalo de 0 a 96 horas, que usualmente leva à letalidade - e "efeito Tóxico" - indicado pela resposta a um estímulo que continua por longo tempo, por períodos que vão de $1 / 10$ até a totalidade do ciclo de vida do organismo (CETESB, 1997).

Os resultados dos testes de toxicidade no reservatório Paiva Castro são:

- 1993: 2-crônico e 4-não tóxico;

- 1994: 5-não tóxico;

- 1995: 1-crônico e 5-não tóxico;

- 1996: 1-agudo, 1-crônico e 2-não tóxico;

- 1997: 1-crônico e 4-não tóxico;

- 1998: 3-crônico e 2-não tóxico.

Segundo a CETESB (1998), embora o reservatório Paiva Castro tenha se apresentado livre de metais pesados e fenóis, os efeitos observados nos testes de toxicidade podem ser associados ao carreamento de substâncias tóxicas para o reservatório, as quais são depositadas irregularmente às suas margens.

Chegando finalmente em PC-002, situado na captação de água da Elevatória Santa Inês, ressaltamos que este é o último ponto de coleta no circuito das vazões do Sistema Cantareira que passam pela bacia do Rio Juquerí. Nessa localidade espera-se verificar os reflexos da depuração das cargas orgânicas poluidoras lançadas no reservatório Paiva Castro, uma vez que neste ponto também não foi constatada influência de contribuições orgânicas significativas. 
No entanto, mesmo aqui, é possível verificar que coliformes totais extrapolam os limites estabelecidos por legislação na maioria dos registros, enquanto coliformes fecais extrapolam freqüentemente, sendo que é possível notar grandes elevações de coliformes totais em 1993 e também em 1995 anual e estiagem (ver Anexo - gráfico 55).

Quanto à série nitrogênio em PC-002, registram-se valores inconstantes que não demonstram nítida tendência de crescimento. Fato que desperta interesse, consiste em eventuais elevações de nitrogênio amoniacal, por vezes com valores superiores aos de nitrato, Isso pode ocorrer em razão da decomposição das algas que proliferam no reservatório (ver Anexo - gráfico 56). Fosfato total e fósforo total também apresentaram valores inconstantes, destacando picos de fosfato total em 1990 chuva e 1992 chuva, é possível verificar que os valores destes parâmetros ocasionalmente apresentam valores superiores aos determinados pela legislação (ver Anexo - gráfico 57).

Nesse ponto os valores de DQO mais elevados apresentam-se em 1996 chuva, 1997 estiagem e 1998 chuva (ver Anexo - gráfico 58). Cor demonstrou maiores valores em 1989 chuva e 1995 anual e chuva, enquanto turbidez registra valores mais elevados em 1989 chuva e 1996 chuva (ver Anexo - gráfico 59). Condutividade apresentou valores constantes, enquanto sólidos em suspensão demonstrou um pico em 1988 chuva (ver Anexo - gráfico 60).

\subsection{ANÁLISE ESPACIAL}

Verificando o percurso das águas do Sistema Cantareira na bacia do Rio Juquerí, desde o desemboque do túnel 5 - PC-301; água dos reservatórios à montante - até a captação da Elevatória Santa Inês - PC-102 - é possível verificar o comportamento dos parâmetros de qualidade de água ao longo desta bacia neste importante manancial (ver imagem de satélite - Anexo).

Dessa maneira, foram elaboradas seis tabelas e seis respectivos gráficos a partir das medianas anuais dos parâmetros selecionados, permitindo visualizar as variações 
espaciais de impacto de lançamentos de cargas poluidoras, bem como, sua depuração ao longo do reservatório Paiva Castro.

Para melhor interpretar o comportamento dos parâmetros de qualidade de água ao longo dos pontos de coleta, torna-se importante destacar uma característica marcante do reservatório Paiva Castro. Ocorre que o tempo de retenção da água nessa represa é relativamente curto em decorrência das grandes vazões constantemente disponibilizadas ao longo do Sistema Cantareira. Um estudo realizado com o intuito de subsidiar ações frente a ocorrências de acidentes envolvendo caminhões com cargas tóxicas sobre o manancial, utilizou de isótopos para determinar o tempo necessário para um contaminante percorrer este corpo d'água. O resultado desta pesquisa determinou que o tempo de retenção da água desde a ponte da rodovia Fernão Dias até a captação da Elevatória Santa Inês - $7.600 \mathrm{~m}$ - é de 5 dias 9 horas 50 minutos e 24 segundos (AOKI, 1996).

Iniciando análise com os parâmetros coliformes totais e fecais (tabela 3 e gráfico 67), considera-se que estes estão intimamente associados com o aporte de esgotos domésticos, então, torna-se simples reconhecer o impacto das contribuições na bacia do rio Juquerí ao se misturarem com as águas provenientes dos reservatórios à montante. Verificamse os baixos níveis de coliformes totais e fecais em PC-301 e as elevações destes registradas em PC-215.

Tabela 3: Resultado das medianas dos valores totais anuais de coliformes totais e coliformes fecais no Reservatório Paiva Castro (1987-1998).

\begin{tabular}{ccc}
\hline Ponto de Coleta & Coliformes Totais nmp/100ml & Coliformes Fecais nmp/100ml \\
\hline PC-301 & 225 & 21,5 \\
PC-215 & 17000 & 3775 \\
PC-104 & 9162 & 3102 \\
PC-103 & 12500 & 1700 \\
PC-102 & 3642 & 468 \\
PC-002 & 2800 & 215 \\
\hline
\end{tabular}




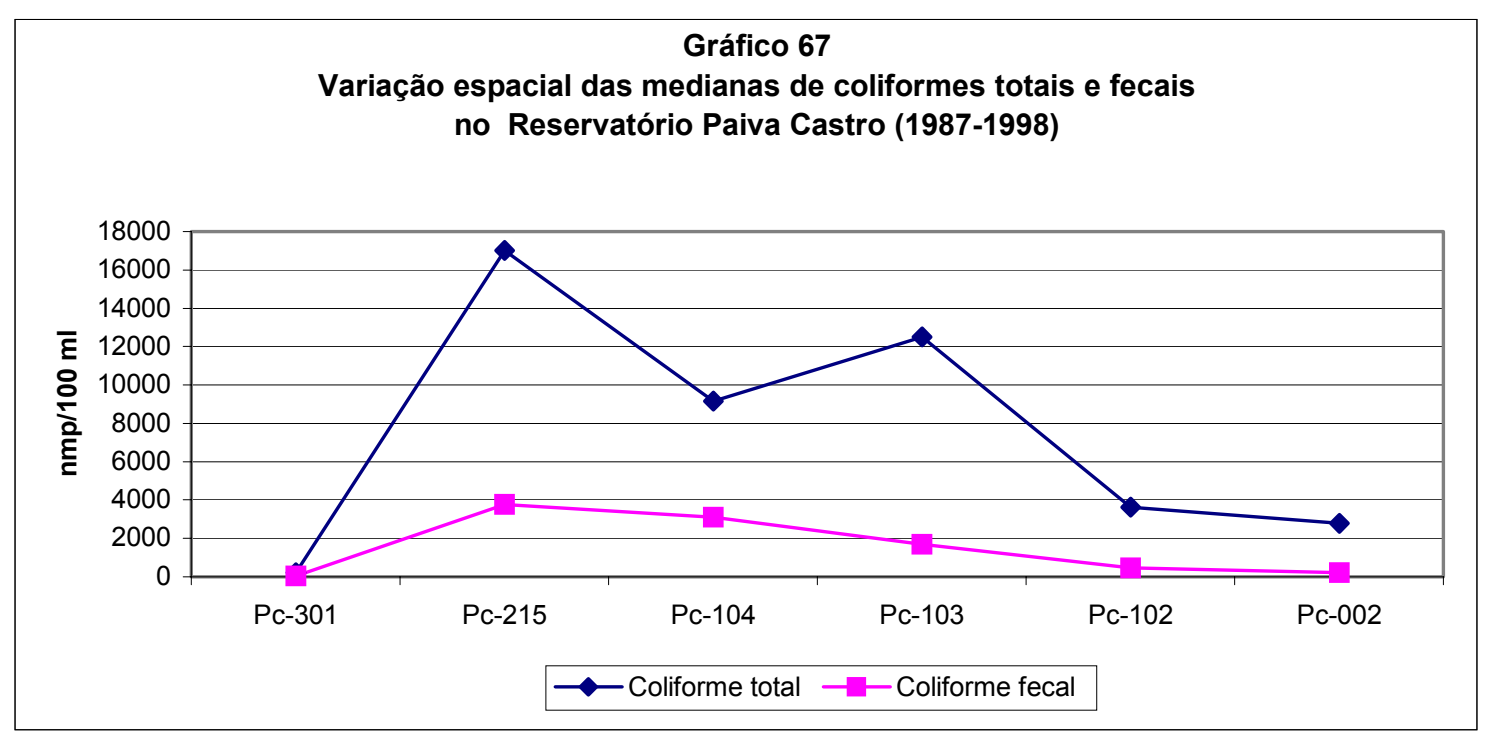

Posteriormente, no tocante aos coliformes totais, há de se notar que PC-104 demonstra redução de valor e subseqüente elevação em PC-103, eventos provavelmente associados à depuração orgânica e posterior contribuição de cargas - em especial do Ribeirão Barreiro - respectivamente. Desse último ponto em diante há uma clara tendência de queda dos valores ao longo do reservatório.

É possível observar que os níveis de coliformes fecais apresentam tendência decrescente ao longo do reservatório, mesmo com os eventuais aportes de cargas poluidoras.

Nota-se que em PC-301, as águas demonstram medianas de coliformes totais e fecais satisfatórias à legislação vigente, enquanto, em PC-002, mesmo com a depuração orgânica ocorrida no decorrer do percurso no reservatório, estes níveis apresentam-se superiores aos limites permissíveis. 
Tabela 4: Resultado das medianas dos valores totais anuais de N.amoniacal, N.nitrito, Nitrato e N.total no Reservatório Paiva Castro (1987-1998).

\begin{tabular}{ccccc}
\hline Ponto de Coleta & $\begin{array}{c}\text { N.amoniacal } \\
\mathrm{mg} / \mathrm{L} \mathrm{N}\end{array}$ & $\begin{array}{c}\text { N.nitrito } \\
\mathrm{mg} / \mathrm{L} \mathrm{N}\end{array}$ & $\begin{array}{c}\text { Nitrato } \\
\mathrm{mg} / \mathrm{L} \mathrm{N}\end{array}$ & $\begin{array}{c}\text { N.total } \\
\mathrm{mg} / \mathrm{L} \mathrm{N}\end{array}$ \\
\hline PC-301 & 0,058 & 0,001 & 0,084 & 0,2775 \\
PC-215 & 0,082 & 0,001 & 0,1075 & 0,3285 \\
PC-104 & 0,078 & 0,002 & 0,14 & 0,345 \\
PC-103 & 0,0595 & 0,002 & 0,14 & 0,32 \\
PC-102 & 0,072 & 0,002 & 0,13 & 0,32 \\
PC-002 & 0,06525 & 0,001 & 0,11 & 0,3275 \\
\hline
\end{tabular}

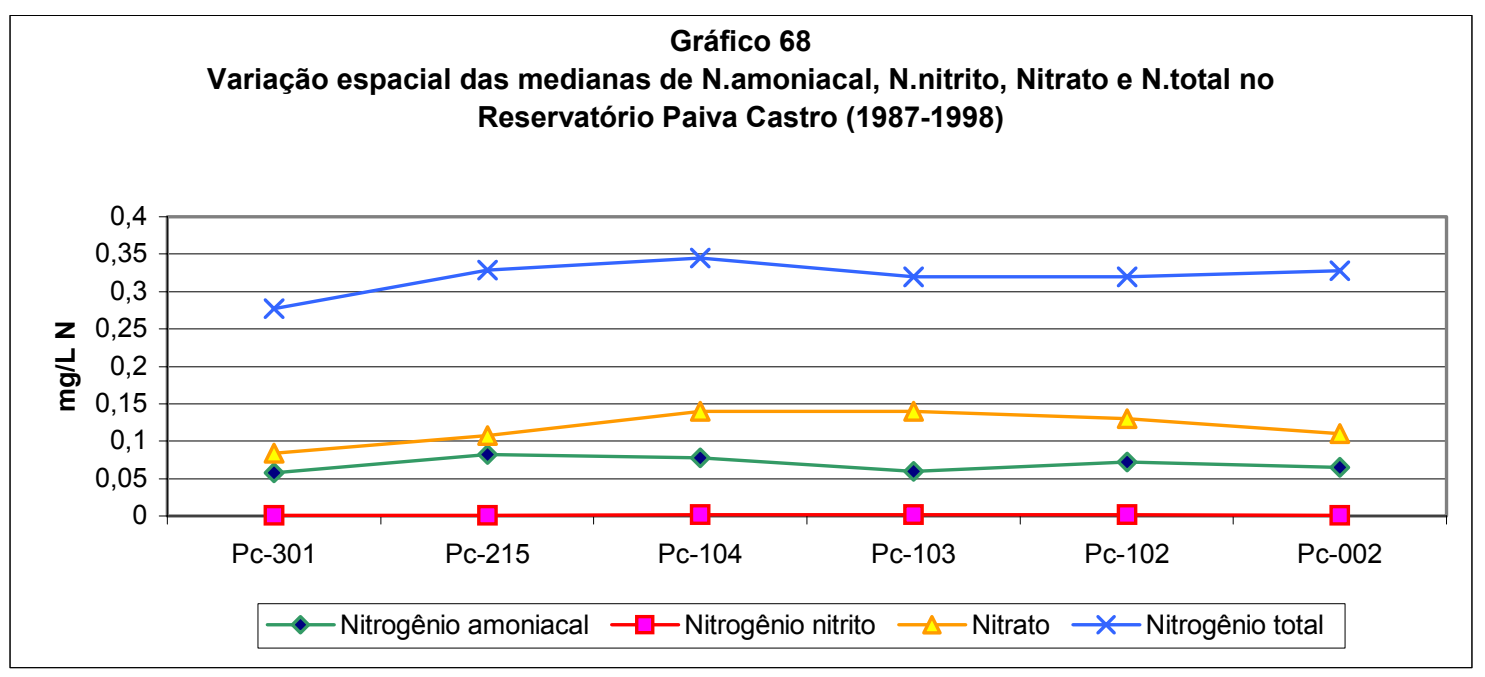

Em se tratando da série Nitrogênio (tabela 4 e gráfico 68) é possível observar que Nitrogênio total e Nitrogênio amoniacal não apresentam picos muito elevados, demonstrando tendência similar entre PC-301 e PC-103 permitindo inferir sobre os efeitos das elevadas cargas poluidoras lançadas à montante de PC-215 e sua subseqüente depuração. Em se tratando de nitrato, este parâmetro apresenta elevação e alta até PC-103 e posterior redução até PC-002. Nitrito esteve constantemente registrando valores baixos, sem elevações representativas. 
Tabela 5: Resultado das medianas dos valores totais anuais de Fosfato total e Fósforo total no Reservatório Paiva Castro (1987-1998).

\begin{tabular}{ccc}
\hline Ponto de Coleta & Fosfato total $\mathrm{mg} / \mathrm{L} \mathrm{PO}_{4}$ & Fósforo total $\mathrm{mg} / \mathrm{L} \mathrm{P}$ \\
\hline PC-301 & 0,01 & 0,00528 \\
PC-215 & 0,03 & 0,01594 \\
PC-104 & 0,02825 & 0,0245 \\
PC-103 & 0,022 & 0,021 \\
PC-102 & 0,018 & 0,013 \\
PC-002 & 0,021 & 0,0144 \\
\hline
\end{tabular}

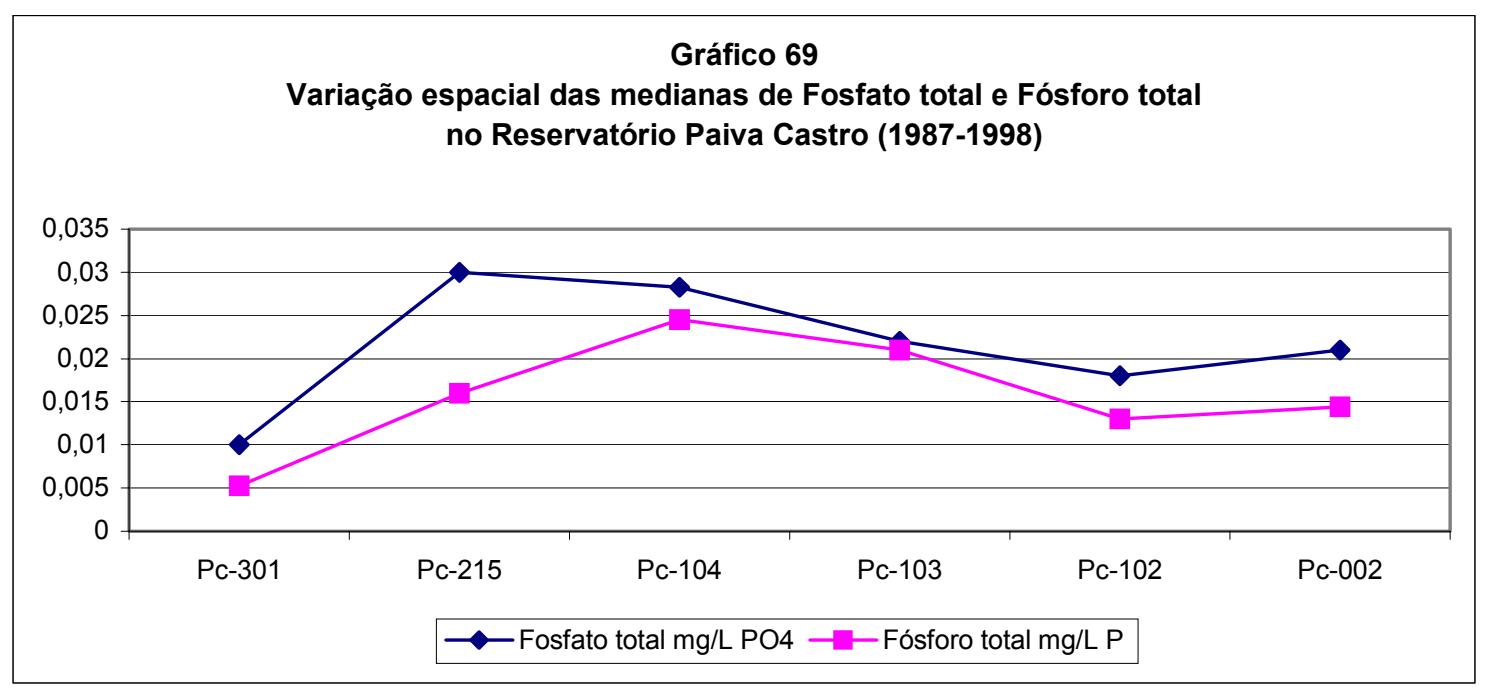

Observando os níveis das medianas de fosfato total e fósforo total registrados (tabela 5 e gráfico 69), também fica evidente a mesma nítida elevação de valores entre PC301 e PC-215. Estes parâmetros, assim como coliformes totais e fecais, reforçam o reconhecimento do impacto sofrido pelas águas dos reservatórios à montante na bacia do Rio Juquerí. Nota-se que os níveis de fósforo total, mesmo em sua maior elevação em PC-104 apresentam-se constantemente abaixo dos permitidos pela legislação. Enquanto fosfato total 
extrapola os valores recomendados quando em seu pico em PC-215 e também posteriormente em PC-104. Após os maiores valores registrados, esses dois parâmetros demonstram tendência de redução de níveis até PC-102, sofrendo ligeira elevação até PC-002.

De acordo com PIVELI (2000), considerando os valores de fósforo total registrados nas medianas podemos classificar o nível trófico do reservatório Paiva Castro como mesotrófico, esta classificação só não se aplica para as águas vindas dos outros reservatórios, uma vez que o valor das respectivas medianas em PC-301, classifica este corpo d'água como oligotrófico.

Tabela 6: Resultado das medianas dos valores totais anuais de DQO no Reservatório Paiva Castro (1987-1998).

\begin{tabular}{cc}
\hline Ponto de Coleta & DQO $\mathrm{mg} / \mathrm{L} \mathrm{O}_{2}$ \\
\hline PC-301 & 3 \\
PC-215 & 7 \\
PC-104 & 6,75 \\
PC-103 & 6,75 \\
PC-102 & 4,75 \\
PC-002 & 4,8 \\
\hline
\end{tabular}




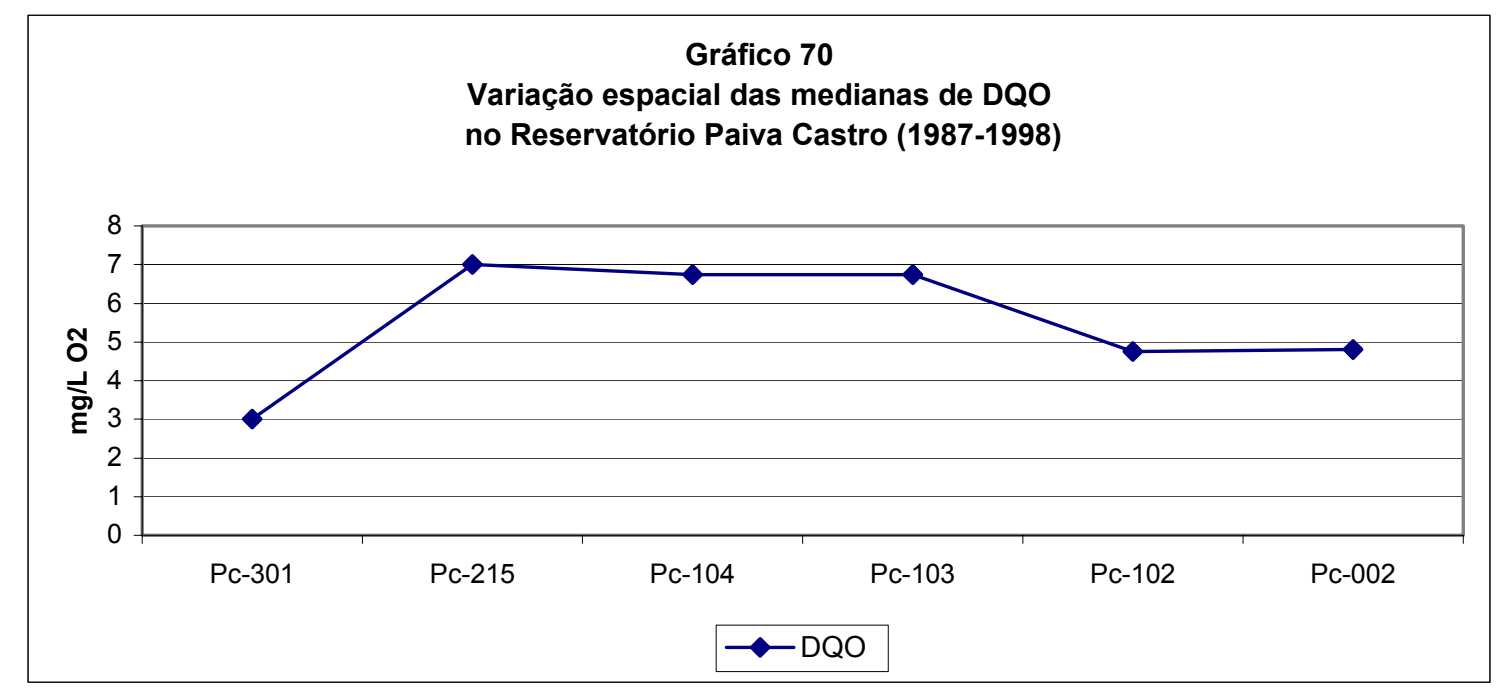

Apesar da impossibilidade de quantificar a matéria orgânica biodegradável que integra o valor da DQO, fato que poderia demonstrar relação direta com o aporte de poluentes orgânicos de origem doméstica, pode-se verificar que ocorre uma elevação abrupta dos valores desse parâmetro entre PC-301 e PC-215 (tabela 6 e gráfico 70), evento previsível em acordo com o conhecimento das fontes poluidoras influentes nesse trecho do manancial.

Níveis elevados de DQO são mantidos em PC-104 e PC-103, fato provavelmente associado aos contínuos despejos de esgotos domésticos à montante destes pontos de coleta. Posteriormente, ocorre queda em PC-102 e ligeira elevação em PC-002, estando esses dois eventos, possivelmente ligados respectivamente a biodegradação da matéria orgânica e à provável elevação de biomassa em virtude da proliferação de algas. 
Tabela 7: Resultado das medianas dos valores totais anuais de Cor e Turbidez no Reservatório Paiva Castro (1987-1998).

\begin{tabular}{ccc}
\hline Ponto de Coleta & Cor UC & Turbidez NTU \\
\hline PC-301 & 5 & 2,45 \\
PC-215 & 15 & 5,9 \\
PC-104 & 12,5 & 4,55 \\
PC-103 & 15 & 5,45 \\
PC-102 & 17,5 & 6,2 \\
PC-002 & 15 & 7,07 \\
\hline
\end{tabular}

\section{Gráfico 71}

Variação espacial das medianas de cor e turbidez no Reservatório Paiva Castro (1987-1998)

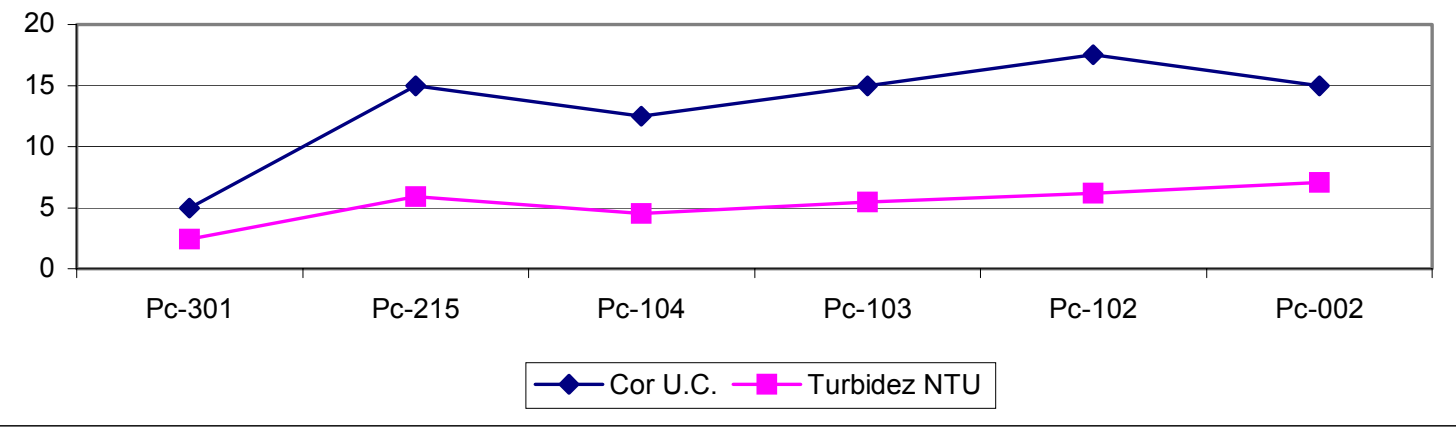

Esses dois parâmetros novamente demonstram forte impacto em PC-215, posteriormente ocorre queda em seus valores em PC-104 e subseqüente elevação (tabela 7 e gráfico 71). É possível que tal comportamento, de elevação abrupta, queda e posterior elevação contínua esteja associado respectivamente ao intenso aporte de esgotos na bacia do Rio Juquerí, posterior depuração, novos aportes e proliferação de algas planctônicas, sendo que este último evento pode ser demonstrado pelos níveis de cor em PC-102 e turbidez em PC-102 e PC-002. 
Tabela 8: Resultado das medianas dos valores totais anuais de Condutividade e Sólidos em Suspensão no Reservatório Paiva Castro (1987-1998).

\begin{tabular}{ccc}
\hline Ponto de Coleta & Condutividade umho/cm & Sólidos em Suspensão mg/L \\
\hline PC-301 & 26,5 & 10 \\
PC-215 & 30,25 & 10 \\
PC-104 & 30,5 & 10 \\
PC-103 & 31 & 10 \\
PC-102 & 31,5 & 10 \\
PC-002 & 30 & 10 \\
\hline
\end{tabular}

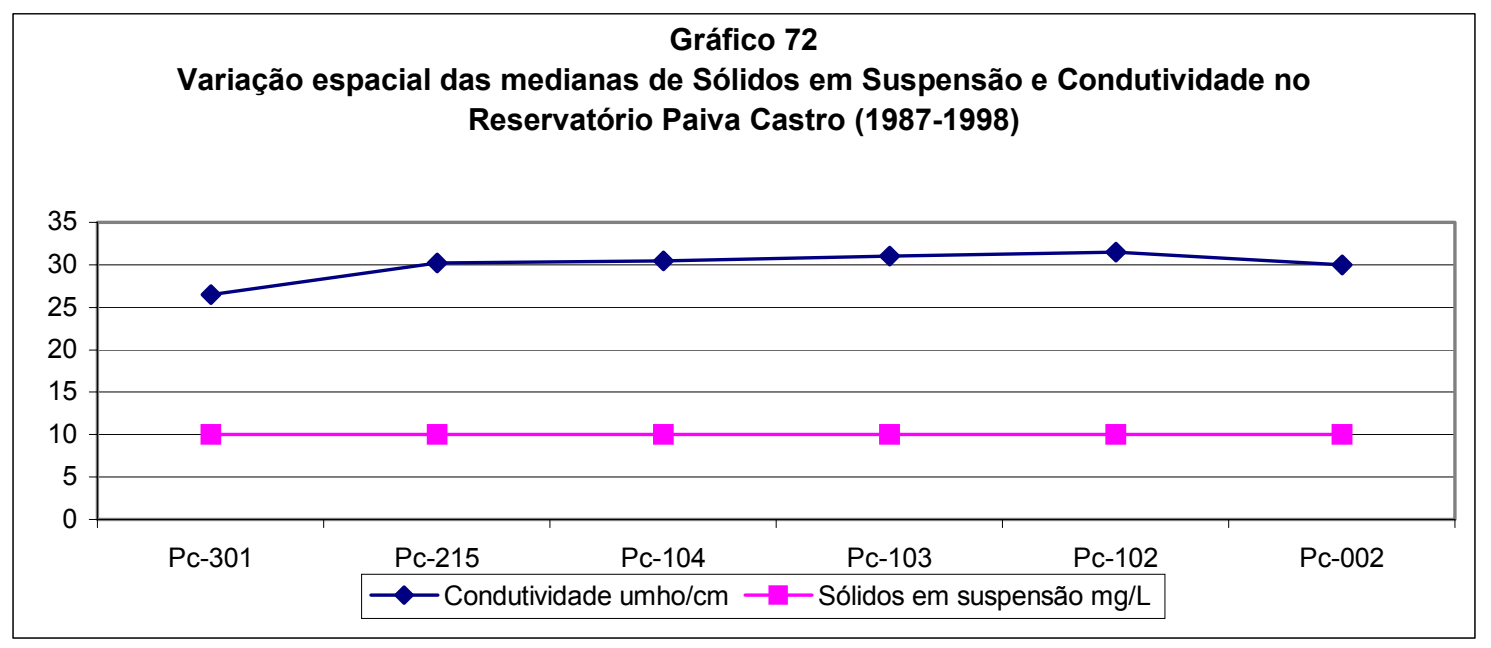

Os níveis de sólidos em suspensão registrados não permitiram verificar variações nem mesmo tendências ao longo do reservatório. Contudo, em se tratando de condutividade podemos reafirmar os impactos das cargas poluidoras na bacia do Rio Juquerí que se tornam evidentes pela elevação de valor em PC-215. Posteriormente, procede contínua elevação até que em PC-002 ocorre redução à nível compatível com PC-215. Podemos inferir que tal comportamento demonstra a disponibilização de nutrientes para a coluna d'água no reservatório Paiva Castro, fenômeno possivelmente associado a mineralização da matéria orgânica alóctone. 


\subsection{FLORAÇÕES DE ALGAS NO RESERVATÓRIO PAIVA CASTRO}

Com o objetivo de demonstrar a queda de qualidade da água no reservatório Paiva Castro de 1985 a 1998 o biólogo da SABESP Osmar Rivelino elaborou, em 1999, um relatório composto do levantamento dos registros de ocorrência de algas nesse corpo d'água.

Tal relatório aponta para a precariedade do saneamento básico do município de Mairiporã como fator causador do comprometimento do reservatório. Afirma ainda, que as algas estão presentes em níveis aceitáveis em todos os reservatórios do Sistema Cantareira, com algumas exceções. Contudo, a partir da cascata que deságua no canal do Rio Juquerí ocorrem florações generalizadas em razão de condições favoráveis relativas a disponibilidade de nutrientes.

Destaca-se nesse relatório a ocorrência de dois períodos de florações de algas do gênero Nannochloris, pertencente ao grupo das clorofíceas - algas verdes. Tais episódios ocorreram entre outubro de 1991 a fevereiro de 1992 e posteriormente de outubro a dezembro de 1998.

RIVELINO (1999) afirma que na ocorrência da floração em 1991 registrou-se aumento substancial do custo do tratamento da água na ETA do Guaraú, tendo em vista as flutuações do pH da água devido ao metabolismo algal. No episódio de 1998, que foi mais intenso, ocorreu "nova floração da mesma alga acarretando transtornos e custos, onde, em média houve um acréscimo de 50\% no custo de produtos químicos, especialmente no sulfato + cloreto nos meses de novembro e dezembro em relação aos meses anteriores".

\subsection{DE GUARAPIRANGA À PAIVA CASTRO}

A represa de Guarapiranga, situada ao sul do município de São Paulo, constitui um importante manancial que vem sofrendo estresse do processo de urbanização da Região Metropolitana de São Paulo. Dados do IBGE (1989 apud BEYRUTH, 1996), indicam que a população urbana na região ocupava $9,9 \%$ da área da bacia em 1988. A população dos municípios envolvidos duplicou da década de 80 para a de 90 e continua aumentando. Dessa 
forma, a bacia de drenagem deste manancial sofre pressões intensas, originadas pela expansão das áreas urbanas, interferindo diretamente na qualidade da água deste reservatório, dificultando o processo de captação e tratamento da água para abastecimento (BEYRUTH, 1996).

Devido a sua importância como manancial da Metrópole Paulista e aos intensos conflitos sócio-ambientais da pressão de urbanização de seu entorno tornou-se objeto de estudo para diversos técnicos no campo da hidrobiologia.

Alguns estudos recentes do Departamento de Saúde Ambiental da Faculdade de Saúde Pública - USP, demonstram haver elementos extremamente relevantes na caracterização deste importante manancial e capazes de indicar as condições resultantes de um extensivo processo de agressões ocorrido ao longo de décadas.

BEYRUTH (1996) demonstra os efeitos da eutrofização neste manancial, sendo que "a comunidade fitoplanctônica local indica tal situação através da alta produção em densidade e biomassa totais, bem como da alta densidade e biomassa de espécies indicadoras de águas eutróficas", registrando a ocorrência de florações de algas. Tais florações são combatidas pela SABESP com a aplicação de algicida (sulfato de cobre) na represa. Ressalta-se ainda, a ocorrência de floração de algas cianofíceas na represa Guarapiranga e os riscos potenciais de suas toxinas para a saúde pública, havendo relatos de distúrbios agudos de saúde provocados pelo consumo desta água, possivelmente relacionados com a presença de biotoxinas nas águas tratadas.

Estudos da comunidade zooplanctônica (CALEFFI, 1994) permitiram verificar que o comportamento destas comunidades demonstrou ser influenciado por fatores físicos e químicos e pelas alterações da qualidade da água decorrentes da eutrofização deste manancial, verificando também, que estes fatores agem sobre os organismos zooplanctônicos principalmente através das modificações da comunidade fitoplanctônica.

ROCHA (1999), em seus estudos, enfatiza a importância da macrofauna bentônica como indicadora de poluição e toxicidade, demonstrando a dominância do grupo Oligochaeta-Tubificidae em área sob influência direta de lançamentos de 
esgotos domésticos "in natura" através de córregos adjacentes, associando o meio com esse grupo indicador de presença de contaminação orgânica.

Estudos microbiológicos realizados por MATTÉ (1995) relatam a presença de bactérias do gênero Aeromonas neste manancial, que são organismos enteropatógenos constituintes da microbióta das águas superficiais que não necessitam de hospedeiro humano ou mamífero para viver e/ou se multiplicar. Estes apresentam relação de proporção direta com a quantidade de matéria orgânica presente na água, havendo portanto, favorecimento pelas descargas de esgotos domésticos. Os riscos de contaminação do ser humano relacionam-se, sobretudo, pelas atividades recreacionais de contato primário com a água infectada, no entanto, existem relatos da presença de Aeromonas mesmo em água clorada.

Estas são algumas das complicações comuns a reservatórios severamente impactados pelos lançamentos de esgotos domésticos, sendo aqui, demonstradas por fatores bióticos.

As considerações anteriores remetem ao fato de que o reservatório Paiva Castro devido às pressões de urbanização em sua bacia de drenagem corre o risco de apresentar acréscimos no aporte de cargas poluidoras, estando sujeito a ocorrências similares às registradas na represa de Guarapiranga.

\subsection{A QUESTÃO ECONÔMICA}

A economia, ciência voltada ao estudo dos fenômenos relativos a produção, distribuição, acumulação e consumo dos bens materiais, mantém relações diretas com o meio ambiente. Desde os primórdios dos estudos desta ciência foram sendo verificadas interações com as questões ambientais, não pelas problemáticas relativas ao descarte de resíduos provenientes da produção ou do consumo, mas sim, pelas preocupações referentes ao esgotamento dos recursos naturais como matérias-primas essenciais aos processos produtivos. 
Com o desenvolvimento dos setores produtivos, com melhor aproveitamento de matérias-primas, novas técnicas e utilização de extensas áreas de produção, a questão do esgotamento de recursos naturais distanciou-se do foco das relações entre meio ambiente e economia.

Uma nova problemática passa a ser encarada verificando-se as agressões ao meio ambiente por parte dos resíduos e poluição oriundos dos sistemas de produção e consumo.

Se no passado, o ambiente só era visto como fonte de recursos, destaca-se a conduta de John Stuart Mill - 1806-1873 (MOURA, 2000), economista famoso, que considerava a terra e a água pela sua função de lazer e bem estar para a satisfação das pessoas e não simplesmente como elementos relativos à alimentação humana. Neste paradigma o meio ambiente passa a ser valorizado também pela sua relação com a qualidade de vida.

Dois importantes conceitos devem ser citados para melhor pontuar as relações aqui discutidas, são eles: externalidade, que representa os efeitos de um determinado sistema produtivo sobre um outro sistema externo, podendo ser positiva ou negativa, no caso das negativas temos todas aquelas que causam algum tipo de dano ao meio ambiente. $\mathrm{O}$ outro conceito a citar é o da internalização dos custos ambientais, cujo significado é justamente de incorporar o dano ambiental de uma externalidade negativa ao custo produtivo deste determinado sistema, isto ocorre através da implementação de medidas que visam a redução das externalidades, por exemplo, se for verificado que uma indústria libera efluentes poluídos para o meio ambiente, a maneira de se reduzir esta externalidade negativa seria implementar um sistema de tratamento de efluentes, ação que iria promover uma elevação nos custos de sua produção.

O procedimento de internalização dos custos ambientais, além de incorporar nova responsabilidade ao sistema produtivo, também serve como elemento regulador de consumo, uma vez que atividades danosas ao meio passam a ter custo elevado, criando um mecanismo de regulação de consumo que por sua vez, contempla a preservação ambiental (MOURA, 2000). 
Uma forma de internalizar os custos dos danos ambientais é obrigar o poluidor ou o utilizador do recurso natural a pagar pelos danos provocados, isso pode se viabilizar através da cobrança de taxas. Ocorre que estas taxas, em parte, acabam por se transferir para o consumidor final através de repasses, porém, mesmo assim, surtem efeito como medida controladora de qualidade ambiental, além de envolver o consumidor que possui responsabilidade moral no processo produtivo (TISDELL, 1994).

Sob esta ética está sendo implementada no Estado de São Paulo a cobrança pelo uso da água, considerada um instrumento de incentivo à racionalização do uso, à recuperação e à preservação da qualidade e quantidade dos recursos hídricos, e também à ocupação mais adequada do solo nas bacias hidrográficas. Esta proposta cria a figura do usuário pagador e gera uma fonte de recursos que deve ser empregada na própria bacia de origem em ações relacionadas à preservação e recuperação dos recursos hídricos (SÃO PAULO - ESTADO, 1997).

Sendo assim, pode-se verificar que a valorização econômica dos recursos naturais possibilita criar mecanismos de proteção e recuperação ambiental. Destaca-se que os procedimentos contraditórios a esses princípios, ou seja, as práticas danosas aos recursos naturais e ao meio ambiente acabam por gerar ônus econômico quando em ocasião de se fazer uso destes recursos, seja por necessidade vital ou simplesmente pelas relações com a qualidade de vida.

Em se tratando do uso da água pelo ser humano, é importante registrar que as águas naturais (aquelas que ainda não sofreram influências antrópicas) em geral não são nocivas para consumo, a não ser por características estéticas como cor, sabor e turbidez, e que só necessitam de tratamento quando sob influência direta ou indireta do homem. A cidade do Rio de Janeiro até 1955 não procedia ao tratamento da água para abastecimento (BRANCO e ROCHA, 1977). Algumas cidades como New York, Madri e Roma utilizam água sem qualquer tratamento, em função da proteção de seus mananciais, permitindo qualidade aceitável para o consumo mesmo in natura (AZEVEDO NETTO, 1965 apud BRANCO e ROCHA, 1977). 
Nesse sentido, deve-se observar que o custo do tratamento de água para abastecimento está vinculado, em grande parte, aos processos de poluição e contaminação dos mananciais, e ainda, este custo é diretamente proporcional ao grau de comprometimento destes corpos d'água.

Para ilustrar esta afirmação pode-se relatar que na represa de Guarapiranga, devido ao nível trófico resultante do cotidiano aporte de esgotos domésticos, adota-se um procedimento de aplicação de toneladas de algicida - sulfato de cobre - na tentativa de conter as constantes florações de algas nas proximidades da captação de água da SABESP. Mesmo assim, ocasionalmente, a água tratada proveniente desta represa apresenta sabor e odor característicos da presença de produtos metabólicos de algas que proliferam excessivamente neste corpo d'água (BEYRUTH, 1996).

Com relação aos custos desta operação, verifica-se que em 1996 foram gastos 8,4 milhões de dólares com algicidas nesta represa, correspondente à $25 \%$ do custo total com produtos químicos aplicados na potabilização destas águas (ROCHA, 1999).

Segundo DI BERNARDO (1995) a remoção de produtos metabólicos das algas presentes em águas brutas requer a utilização de tratamentos mais sofisticados como oxidação, extração por meio de aeração e adsorção em carvão ativado em pó. Sendo que estes procedimentos não constam nos sistemas convencionais, encarecendo o tratamento da água para abastecimento.

RIVELINO (1999) ao demonstrar ocorrências de florações de algas clorofíceas no reservatório Paiva Castro, relaciona tais eventos com a elevação do consumo de insumos e de energia elétrica na ETA do Guaraú e seus respectivos acréscimos de custos. Destaca-se que no episódio mais crítico em 1998 houve um acréscimo de cerca de 50\% no consumo de produtos químicos. Além disso, o autor ressalta que "se a floração fosse de uma alga que ao invés de aumentar o pH, tivesse como conseqüência o gosto e odor perceptíveis à população, seria necessário o carvão ativado. Partindo-se do pressuposto que o atualmente disponível fosse o recomendado, e ainda que se utiliza uma dosagem de $15 \mathrm{mg} / \mathrm{l}$, seriam necessários 1.300 ton/mês a um custo de $R \$ 1.326 .000,00$ ou 16.000.000,00 anuais. Tal cifra justificaria 
com folga que em dois ou três anos pagaria o equacionamento dos efluentes da cidade de Mairiporã'.

\subsection{A CONTAMINAÇÃO DO MANANCIAL COMO RISCO À SAÚDE PÚBLICA}

Ao consumir água potável, o usuário dispõe apenas dos sentidos para verificar a sua qualidade. E sendo assim, pode-se avaliar critérios comuns como aparência, odor e o sabor. Nesse sentido, é possível rejeitar o consumo da água que esteja turva, com odor ou mesmo sabor desagradável. Ocorre que a água aparentemente de boa qualidade, pode estar contendo uma série de patógenos ou mesmo substâncias químicas nocivas à nossa saúde, elementos tais que não são reconhecidos pelos órgãos dos sentidos (QUEIROZ, 1994).

Grande número de substâncias químicas que podem estar presentes na água tratada passam desapercebidas ao consumo humano, acarretando riscos à saúde dos consumidores tanto a curto como longo prazo. No intuito de proteger a saúde pública desses efeitos a OPS - Organização Panamericana de Saúde (1987 apud QUEIROZ, 1994) estabeleceu valores guias para a ocorrência de determinadas substâncias potencialmente nocivas que são propostos para integrar os critérios de qualidade da água para consumo, os quais variam em cada país ou local. Estes valores foram estabelecidos no intuito de salvaguardar a saúde dos consumidores mesmo a longo prazo sob exposição destes fatores de risco. A determinação destes valores ocorre principalmente através da realização de testes de toxicidade em laboratórios com a exposição de animais.

Entre essas substâncias potencialmente nocivas à saúde humana, podemos mencionar os metais pesados. Estes podem surgir nas águas naturais devido às descargas de efluentes industriais como das indústrias extrativistas de metais, de tintas e pigmentos e, especialmente as galvanoplastias, que se espalham em grande número nas periferias das grandes cidades. A presença de metais pesados nas águas naturais pode encarecer e até inviabilizar a utilização destas para abastecimento, tendo em vista que as estações de 
tratamento convencionais não os removem eficientemente e os tratamentos especiais necessários são demasiadamente caros (PIVELI, 1998). No entanto, os metais pesados não foram incluídos como objeto de estudo nessa dissertação por motivo de carência de dados disponíveis a respeito.

Outros elementos potencialmente nocivos e passíveis de ocorrer nas águas tratadas, inclusive as provenientes do Sistema Cantareira, com grande importância do ponto de vista da saúde pública são os compostos trihalometanos e os produtos metabólicos das algas, sobretudo das algas cianofíceas.

Os trihalometanos são compostos químicos formados da combinação de um átomo de carbono, um de hidrogênio e três de cloro, bromo ou iodo (sós ou em conjunto). Entre as 10 combinações diferentes destes 5 átomos acima, somente 4 ocorrem de forma significativa: triclorometano (clorofórmio), bromodiclorometano, dibromoclorometano e tribromometano. Sua formação ocorre no processo de tratamento químico da água, após a cloração que produz reação do cloro com os ácidos húmico, fúlvico e himatomelânico, sendo que estes precursores são comuns em águas brutas, devido à decomposição da matéria vegetal ou do metabolismo da biota aquática (QUEIROZ, 1994).

O tratamento da água implica na utilização de agentes químicos que podem afetar a saúde daqueles que a utilizam. O cloro é o agente mais utilizado com a finalidade de destruir ou inativar os organismos causadores de enfermidades, fornecendo, de acordo com sua dosagem, uma quantidade remanescente que protege a água de posteriores contaminações (TOMINAGA e MIDIO, 1999). No entanto as dosagens de cloro relacionam-se ao aparecimento dos compostos trihalometanos (QUEIROZ, 1994).

É importante destacar que a formação dos trihalometanos ocorre com intensidade no tratamento de águas contendo altos níveis de material orgânico, através do processo de pré-cloração que é adotado nas ETA's como oxidante químico capaz de facilitar a posterior coagulação e floculação (PIVELI, 1998). Nota-se que a formação de tais compostos pode ser associada aos teores de matéria orgânica presente na água (TOMINAGA e MIDIO, 1999). 
Os efeitos destes compostos sobre a saúde humana ainda não foram completamente avaliados (TOMINAGA e MIDIO, 1999). Porém, com relação às concentrações observadas em água potável, o risco mais sério seria o efeito carcinogênico verificado em animais e a suposição de que estes efeitos poderiam ocorrer de forma similar nos seres humanos que consomem esta água (QUEIROZ, 1994). PIVELI, (1998) destaca que dentre estes compostos, maior atenção é voltada ao clorofórmio, por ser presente em maior quantidade nas águas tratadas.

O padrão de potabilidade para trihalometanos é de $100 \mu \mathrm{g} / \mathrm{L}$, constando forte tendência de se reduzir para nível inferior. Nos EUA, estudos epidemiológicos apontam para a necessidade de reduzir este padrão para $10 \mu \mathrm{g} / \mathrm{L}$, fator que irá acarretar problemas para diversas estações de tratamento de água que não estariam habilitadas para obedecer tal restrição (PIVELI, 2000).

A ingestão da água não constitui a única forma de exposição aos trihalometanos. Diante da alta volatilidade apresentada por estes compostos verifica-se que na utilização de água tratada com cloro para banhos ou tarefas domésticas, a população também se expõe à esses compostos. Estudos experimentais indicam que a exposição ao clorofórmio por inalação durante um banho de 8 minutos ocorre de forma 6 vezes mais intensa do que pela ingestão da mesma água num período de 24 horas (WORLD HEALTH ORGANIZATION, 1996 apud TOMINAGA e MIDIO, 1999).

Em se tratando dos produtos metabólicos de algas, ressalta-se que a ocorrência destes organismos em reservatórios de abastecimento, sobretudo onde os nutrientes encontram-se em níveis elevados, acarreta o acúmulo desses organismos nos filtros da estação de tratamento de água e também no próprio reservatório, onde podem atingir concentrações tóxicas ou entrar em decomposição, gerando produtos tóxicos passíveis de permanecer nas águas tratadas (BRANCO, 1986).

Segundo CARMICHAEL (1992 apud BEYRUTH, 1996) o grupo das cianofíceas constitui a maior fonte de toxinas produzidas naturalmente - biotoxinas - na superfície de mananciais de água doce. Essas cianotoxinas produzem envenenamentos intermitentes e repetidos de animais em várias regiões do planeta. 
DI BERNARDO (1995) cita que toxinas produzidas por algas azuis podem causar distúrbios gastro-intestinais, respiratórios, neurológicos e alergias ao ser humano. A contaminação do ser humano pode ocorrer por contato direto com água contendo florescimentos ou por ingestão de água mesmo que tratada por sistema convencional.

Por volta de 40 espécies de cianofíceas são relatadas pelo mundo como causadoras de intoxicações em animais e no ser humano, principalmente pela ingestão de água contaminada. Dentre as cianofíceas verificadas em florações, o gênero Microcystis, principalmente $M$. aeruginosa, está associado a mais de $65 \%$ das intoxicações relatadas. Outros gêneros também tem causado problemas de saúde, são eles: Oscillatoria, Anabaena, Aphanizomenon, Nodularia, Trichodesmium e Cylindrospermopsis. Vale ressaltar, que nem todas as linhagens de uma determinada espécie são produtoras de toxinas, sendo que este fato pode estar relacionado com fatores genéticos e/ou ambientais (ZAGATTO, 1997).

Quanto aos efeitos à saúde do ser humano, podemos verificar que cerca de 10.000 pessoas apresentaram distúrbios gastrointestinais relacionados ao consumo de água de manancial com floração de algas nos EUA em 1930. Posteriormente em 1975, também nos EUA, Pensilvânia, aproximadamente 5.000 pessoas tiveram os mesmos sintomas ao consumirem água com floração de Schizothrix calcícola. E ainda, na Austrália, cerca de 150 pessoas foram hospitalizadas com hepatoenterite, pelo fato de consumir água com floração de Cylindrospermopsis raciborskii, espécie também encontrada em mananciais da Grande São Paulo, nota-se que tal floração havia sido tratada com sulfato de cobre, algicida que promove lise celular e que no caso promoveu a liberação da toxina para a colouna d'água (ZAGATTO, 1997).

Registra-se aqui um ponto negativo na aplicação de tal algicida no combate às florações, verificando que além da liberação direta das toxinas, a decomposição destes organismos também gera toxinas na água (BRANCO, 1986), além de disponibilizar nutrientes, possibilitando a ocorrência de novas florações.

BEYRUTH e col. (1992 apud BEYRUTH, 1996) relatou uma floração da cianobactéria Anabaena solitaria na represa Guarapiranga associando tal fato a distúrbios gastrointestinais e hepáticos na população abastecida pelas águas tratadas deste manancial, 
constituindo o primeiro caso registrado na literatura científica de ocorrência de danos à saúde pública por cianobactérias em águas paulistas. Relatou ainda, alergias de pele e vias respiratórias, promoção de tumores, efeitos neurotóxicos, lesões hepáticas, renais, pulmonares, das glândulas adrenais, intestinais e hemorragias como eventos nocivos à saúde associados ao florecimento das algas azuis.

No ano de 1996 em Caruaru, Pernambuco, houve um caso de mortalidade de 70 de pessoas que faziam hemodiálise em uma clínica que utilizava água de uma represa com floração de algas cianofíceas (ZAGATTO, 1997), mais especificamente Microcystis aeruginosa, espécie produtora da biotoxina conhecida como microcistina, provável causadora das mortes das pessoas em tratamento (BEYRUTH, 1996).

VASCONCELOS (1999) demonstra a atenção despendida à questão das biotoxinas provenientes das algas cianofíceas em águas de abastecimento em Portugal. $\mathrm{O}$ autor afirma que não existem programas contínuos de monitoramento e que as estações de tratamento de água daquele país não se encontram devidamente equipadas para remover tais contaminantes, todavia, os locais abastecidos por água de reservatórios com eventuais problemas de florações de água são monitorados quanto a presença de microcistina em concentrações superiores a $1 \mathrm{ug} / \mathrm{L}$ nas águas tratadas, e quando tal ocorrência é identificada, a população servida recebe a recomendação de não utilizar tal água para beber ou cozinhar.

No caso da água potável contaminada por agentes biológicos patogênicos, os efeitos deletérios à saúde humana normalmente são agudos, conhecidos e facilmente diagnosticáveis.

No entanto, em se tratando das substâncias químicas tóxicas ou mesmo os produtos metabólicos das algas, estes geralmente conferem efeitos crônicos ao ser humano, tendo em vista que intoxicações agudas estariam relacionadas a altos teores de contaminantes na água, os quais impossibilitam a ingestão devido à associação com problemas de sabor, odor e cor. Os contaminantes químicos acarretam doenças progressivas e crônicas tais como o câncer, porém, os seus sinais deletérios são muito inespecíficos e pouco conhecidos, em razão disso, não lhes é dada tanta importância e atenção quanto aos microorganismos patogênicos que apresentam efeitos imediatos e bem conhecidos (QUEIROZ, 1994). 
É imprescindível que tais substâncias tóxicas recebam maior atenção com relação à sua ocorrência nos mananciais e sobretudo nas águas tratadas para abastecimento. Tais elementos, são passíveis de ocorrer nas águas do Sistema Cantareira devido ao processo de eutrofização e posterior tratamento convencional na Estação de Tratamento de Água do Guaraú (SABESP, 1982). Estes eventos podem ser mais facilmente reconhecidos à partir do Reservatório Paiva Castro devido ao aporte de cargas orgânicas poluidoras, provenientes de esgotos domésticos que promovem o enriquecimento da água com nutrientes.

As substâncias tóxicas passíveis de causar danos à saúde humana podem ser observadas nas águas naturais através da realização de testes de toxicidade. Estes testes consistem da determinação do potencial tóxico de um agente presente na água pela resposta de organismos vivos verificada por efeitos deletérios agudos ou crônicos (CETESB, 1999).

É recomendável o contínuo monitoramento de elementos potencialmente nocivos ao ser humano mesmo nas águas tratadas, e ainda, deve-se verificar os índices de saúde relacionados à intoxicação por água contaminada.

Também é importante observar a presença de nutrientes na coluna d'água dos reservatórios, uma vez que estes podem indicar o nível trófico do manancial (ESTEVES, 1998), portanto, podendo alertar sobre as condições favoráveis às florações de algas.

Ocorre que o abastecimento de água de Mairiporã e seu tratamento, realizados também pela SABESP sediada no município, procede a partir da captação no reservatório à jusante do lançamento da estação de tratamento de esgotos e da contribuição de fontes poluidoras de demais bairros que não são atendidos por tal estação. Estes eventos podem ser observados pelos níveis de contaminantes registrados em PC-104, situado no corpo do reservatório, nas proximidades da captação da estação de tratamento.

Tal ponto de coleta registrou valores elevados de coliformes totais e fecais, indicando contaminação recente por esgotos através da série nitrogênio, além de altos valores para DQO. O processo de tratamento utilizado pela ETA de Mairiporã consta como convencional com adoção do processo de pré-cloração. Sob esses fatos deve-se considerar a possibilidade da geração de compostos trihalometanos no tratamento da água em razão da 
matéria orgânica oriunda de esgotos servir como precursora na formação de tais compostos na ocasião da pré-cloração.

Já na captação de água da Elevatória Santa Inês temos o ponto de coleta da SABESP intitulado de PC-002. A análise dos parâmetros de qualidade de água nesse ponto não demonstram níveis de contaminantes tão elevados como os demais no corpo do reservatório, nem mesmo ocorrem aqui fontes poluidoras comprometedoras. No entanto, mesmo com os indícios da depuração orgânica ocorrida ao longo do manancial, deve-se verificar os agravantes relacionados ao nível trófico e a proliferação das algas planctônicas nessa localidade. Considerações pertinentes a essa problemática remetem-se as florações de algas do gênero Nannochloris em 1991/92 e 1998 relatadas por RIVELINO (1999).

Nessas condições verificam-se probabilidades de ocorrência de florações de algas tóxicas nesse reservatório, mesmo se não considerarmos a presença de cepas produtoras de biotoxinas, há de se alertar para a possibilidade da formação dos trihalometanos, havendo adoção do processo de pré-cloração quando na presença de elevados teores de matéria orgânica oriunda das florações algais. Estes eventos conferem riscos de comprometimento das águas do Sistema Cantareira sob a ótica da saúde pública, uma vez que o sistema de tratamento adotado na ETA do Guaraú consta como modelo convencional (SABESP, 1982), limitado em sua capacidade de eliminar tais impurezas. 


\section{CONCLUSÕES}

Os resultados obtidos por meio das análises das amostras de água nos vários pontos de coleta permitem as seguintes conclusões:

- Verificam-se expressivos impactos nas águas do Sistema Cantareira na bacia do Rio Juquerí, o que fica evidente pela qualidade da água na saída do túnel 5 - que traz águas dos reservatórios à montante - bem como pelos elevados níveis de poluentes nos afluentes do reservatório sob influência das áreas urbanizadas do município de Mairiporã.

- Os pontos de coleta sob influência da desordenada ocupação urbana do entorno onde há carência de saneamento básico demonstram claramente os efeitos do lançamento dos esgotos domésticos no manancial, comprometendo a qualidade sanitária da água.

- Ocorrem também altos níveis de poluição no Ribeirão Itaim, este ponto de coleta encontra-se à jusante do lançamento do efluente da estação de tratamento de esgotos do município, refletindo a precariedade do sistema de tratamento frente às vazões de esgotos da área central da cidade.

- Ainda que se observe acentuado crescimento demográfico no município de Mairiporã não é possível, com base nos dados ora disponíveis, reconhecer uma progressão dos níveis dos parâmetros da qualidade de água utilizados na determinação proporcionalmente ao aumento populacional. No entanto, alguns índices e concentrações elevados de poluentes indicam situação de risco ao manancial, principalmente do ponto de vista da eutrofização, fato que pode ser confirmado pelos registros de florações de algas Nannochloris em 1991-92 e 1998.

- Valores de parâmetros relacionados à sazonalidade de acordo com a divisão proposta neste estudo não demonstram tendência à elevação ou queda de níveis se considerados os períodos de chuva e estiagem. Tal fato pode ser justificado pelas grandes vazões disponibilizadas constantemente para o Sistema Cantareira provenientes das reversões de corpos d'água de outras bacias. 
- Os elevados valores de coliformes totais e fecais no ponto de coleta PC-002 podem ser explicados pela velocidade da água nesse reservatório e devido à expressiva distância deste com as fontes de poluição por esgotos domésticos.

- A análise espacial dos valores disponíveis no banco de dados da SABESP permitiu verificar as elevações dos níveis dos parâmetros de qualidade da água na Bacia do Rio Juquerí, apontando também a ocorrência de posterior depuração orgânica e subseqüente disponibilização de nutrientes para a coluna d'água, fato que pode ter relação direta com as florações algais que ocorrem no reservatório. 


\section{REFERÊNCIAS BIBLIOGRÁFICAS}

Ab'Sáber AN. O Reservatório do Juqueri, na área de Mairiporã: estudos básicos para defesa ambiental e ordenação dos espaços envolventes. Geogr e Planej 1978; 32:1-28.

Aoki PE, Bombonato Jr C, Maloszewski P. Isotopes in water resources management. In: International atomic agency. Viena; 1996.

Azevedo W. A cidade de Mairiporã em números. Mairiporã On line [página na internet]. 2000. Disponível em <URL:http://www.mairiporã.com.br/cidade/ dados.htm> [30/03/2000].

Beyruth Z. Comunidade Fitoplanctônica da Represa de Guarapiranga: 1991-92. Aspectos ecológicos, sanitários e subsídios para reabilitação da qualidade ambiental. São Paulo; 1996.[Tese de doutorado - Faculdade de Saúde Pública da USP].

Branco SM, Rocha AA. Poluição, proteção e usos múltiplos de represas. São Paulo: CETESB; 1977.

Branco, SM. Hidrobiologia aplicada à engenharia sanitária. 3a ed. São Paulo: CETESB/ASCETESB; 1986.

Born GCC. Levantamento sobre a população usuária do Reservatório Paiva Castro e do Canal do Rio Juquerí. São Paulo: Vitae Civilis; 2000.

Caleffi S. A Represa de Guarapiranga: estudo da comunidade zooplanctônica e aspectos da eutrofização. São Paulo: 1994 [Dissertação de mestrado - Faculdade de Saúde Pública USP].

[CBH-AT] Comitê da Bacia Hidrográfica do Alto Tietê. Atuação do CDHU na subregião Juqueri - Cantareira. São Paulo; 1997.

[CETESB] Companhia de Tecnologia de Saneamento Ambiental do Estado de São Paulo. Lagoas de estabilização de Mairiporã. São Paulo; 1974.

[CETESB] Companhia de Tecnologia de Saneamento Ambiental do Estado de São Paulo. Relatório da inspeção sanitária e amostragem no sistema de abastecimento de água no município de Mairiporã. São Paulo; 1976. [relatório técnico]

[CETESB] Companhia de Tecnologia de Saneamento Ambiental do Estado de São Paulo. Subsídios para uma política de controle de poluição das águas na sub-bacia do Rio Juquerí. São Paulo; 1982. [Relatório Técnico].

[CETESB] Companhia de Tecnologia de Saneamento Ambiental do Estado de São Paulo. Relatório de qualidade das águas interiores do Estado de São Paulo. São Paulo; 1987. 
[CETESB] Companhia de Tecnologia de Saneamento Ambiental do Estado de São Paulo. Guia de coleta e preservação de amostras de água. São Paulo: CETESB; 1988.

[CETESB] Companhia de Tecnologia de Saneamento Ambiental do Estado de São Paulo. Relatório de qualidade das águas interiores do Estado de São Paulo. São Paulo; 1988.

[CETESB] Companhia de Tecnologia de Saneamento Ambiental do Estado de São Paulo. Relatório de qualidade das águas interiores do Estado de São Paulo. São Paulo; 1989.

[CETESB] Companhia de Tecnologia de Saneamento Ambiental do Estado de São Paulo. Relatório de qualidade das águas interiores do Estado de São Paulo. São Paulo; 1990.

[CETESB] Companhia de Tecnologia de Saneamento Ambiental do Estado de São Paulo. Relatório de qualidade das águas interiores do Estado de São Paulo. São Paulo; 1991.

[CETESB] Companhia de Tecnologia de Saneamento Ambiental do Estado de São Paulo. Relatório de qualidade das águas interiores do Estado de São Paulo. São Paulo; 1992.

[CETESB] Companhia de Tecnologia de Saneamento Ambiental do Estado de São Paulo. Relatório de qualidade das águas interiores do Estado de São Paulo. São Paulo; 1993.

[CETESB] Companhia de Tecnologia de Saneamento Ambiental do Estado de São Paulo. Relatório de qualidade das águas interiores do Estado de São Paulo. São Paulo; 1994.

[CETESB] Companhia de Tecnologia de Saneamento Ambiental do Estado de São Paulo. Relatório de qualidade das águas interiores do Estado de São Paulo. São Paulo; 1995.

[CETESB] Companhia de Tecnologia de Saneamento Ambiental do Estado de São Paulo. Relatório de qualidade das águas interiores do Estado de São Paulo. São Paulo; 1996.

[CETESB] Companhia de Tecnologia de Saneamento Ambiental do Estado de São Paulo. Relatório de qualidade das águas interiores do Estado de São Paulo. São Paulo; 1997.

[CETESB] Companhia de Tecnologia de Saneamento Ambiental do Estado de São Paulo. Relatório de qualidade das águas interiores do Estado de São Paulo. São Paulo; 1998.

[CETESB] Companhia de Tecnologia de Saneamento Ambiental do Estado de São Paulo. Relatório de qualidade das águas interiores do Estado de São Paulo. São Paulo; 1999.

[CETESB] Companhia de Tecnologia de Saneamento Ambiental do Estado de São Paulo. Guia de coleta e preservação de amostras de água. São Paulo: CETESB; 1988.

[CONAMA] Conselho Nacional de Meio Ambiente. Resoluções CONAMA - 1984/86. Brasília: Ministério do desenvolvimento urbano e meio ambiente; 1986. 
[DAEE] Departamento de Águas e Energia Elétrica do Estado de São Paulo. Desenvolvimento global dos recursos hídricos das Bacias do Alto Tietê e Cubatão. São Paulo: HIBRACE; 1966. v.1.

Di Bernardo L. Algas e suas influências na qualidade das águas e nas tecnologias de tratamento. Rio de Janeiro: ABES; 1995.

[DNER] Departamento Nacional de Estradas de Rodagem. Rodovia BR381 - Fernão Dias trecho: Belo Horizonte - São Paulo - Estudo de Impacto Ambiental da Duplicação. tomo I. São Paulo: Departamento Nacional de Estradas de Rodagem; 1993a.

[DNER] Departamento Nacional de Estradas de Rodagem. Rodovia BR381 - Fernão Dias trecho: Belo Horizonte - São Paulo - Estudo de Impacto Ambiental da Duplicação. tomo IV. São Paulo: Departamento Nacional de Estradas de Rodagem; 1993 b.

[EMPLASA] Empresa Metropolitana de Planejamento da Grande São Paulo SA. Sumário de dados da Grande São Paulo [dados em CD ROM]. São Paulo: Emplasa, 1997.

[EMPLASA] Empresa Metropolitana de Planejamento da Grande São Paulo SA. Banco de dados sobre os Municípios da Região Metropolitana de São Paulo [dados em CD ROM]. Akttom sistemas. São Paulo: Emplasa; 1999.

[EMPLASA] Empresa Metropolitana de Planejamento da Grande São Paulo SA. Metrópoles em Dados. Emplasa [página na internet]. 2000. Disponível em <URL:http://www.emplasa.sp.gov.br/metrodados.htm> [04/04/2000].

Esteves FA. Fundamentos de limnologia. 2a ed. Rio de Janeiro: Interciência; 1998.

[FESPSP] Fundação Escola de Sociologia e Política de São Paulo. Rodoanel Metropolitano de São Paulo - trecho oeste - estudo de impacto ambiental. São Paulo: Governo do Estado de São Paulo; 1997. v.1.

Forest M. Cantareira - Patrimônio Arquitetônico e Natural. São Paulo: Imprensa Oficial; 2000.

HIDROPLAN. Plano integrado de aproveitamento e controle de recursos hídricos das bacias Alto Tietê, Piracicaba e Baixada Santista. São Paulo: São Paulo (Estado) Secretaria de Recursos Hídricos; 1995.

Hoefel JL, Viana RM. Impactos de barragens e transformação regional - considerações sobre a implantação dos reservatórios do Sistema Cantareira na região bragantina. Gestão e Desenvolvimento. 1996; 1: 87-102.[Publicação da Universidade São Francisco - Bragança Paulista - SP]. 
[IF] Instituto Florestal. Plano de manejo para o Parque Estadual da Cantareira. São Paulo; 1974. [Boletim técnico no 10$]$.

[IF] Instituto Florestal. A reserva da biosfera do cinturão verde de São Paulo. São Paulo; 1994. [Apostila informativa].

Jacobi PR, coordenador. Conflitos sócio Ambientais - Diagnóstico da Cidade de São Paulo: Mananciais da metrópole. Cadernos Cedec 1995; 45: 47-55.

Matté MH. Pesquisa de Aeromonas spp potencialmente patogênicas em alguns pontos da Represa de Guarapiranga destinados à recreação e captação para abastecimento público. São Paulo; 1995 [Dissertação de mestrado - Faculdade de Saúde Pública - USP].

Matté MH. Ribotipagem de Aeromonas hydrophila, Aeromonas caviae, Aeromonas sóbria e Aeromonas jandaei, potencialmente patogênicas, isoladas de amostras de água do Reservatório de Guarapiranga, São Paulo. São Paulo; 1996 [Tese de doutorado Faculdade de Saúde Pública - USP].

Moróz IC. Problemas ambientais da Bacia do Alto Juqueri - setor norte das áreas de proteção aos mananciais da RMSP. In: V Simpósio de Geografia Física Aplicada; 1993 dez; São Paulo, Brasil. São Paulo: Faculdade de Filosofia, Letras e Ciências Humanas da USP; 1993. p.329-31.

Moura LAA. Economia ambiental - gestão de custos e investimentos. São Paulo: Editora Juarez de Oliveira; 2000.

Nucci NLR, Silva RJC, Araújo JLB. Proteção de mananciais da Região Metropolitana de São Paulo. In: São Paulo (Estado). O desafio metropolitano. Série: Documentos-1. São Paulo: Governo do Estado de São Paulo; 1976. p.83-105.

Piveli RP. Qualidade das Águas. São Paulo; 1998 [Apostila da disciplina Qualidade Ambiental do departamento de Saúde Ambiental da Faculdade de Saúde Pública - USP].

Piveli RP. Qualidade das Águas. São Paulo; 2000 [Apostila da disciplina Qualidade Ambiental do departamento de Saúde Ambiental da Faculdade de Saúde Pública - USP].

Queiroz IR. Avaliação toxicológica da qualidade da água distribuída à população do Estado de São Paulo. São Paulo: CETESB; 1994 [Relatório técnico].

Rivelino O. Conseqüência do constante aumento de poluição no Reservatório Paiva Castro. São Paulo: SABESP; 1999 [Relatório técnico].

Rocha AA. Fatos históricos do saneamento. São Paulo: Scortecci; 1997. 
Rocha SM. Macroinvertebrados bentônicos como indicadores de poluição na Represa Guarapiranga - SP. São Paulo; 1999 [Dissertação de mestrado - Faculdade de Saúde Pública-USP].

Rutkowski E. Desenhando a bacia ambiental - subsídios para o planejamento das águas doces metropolitan(izad)as. São Paulo; 1999.[Tese de doutorado - Faculdade de Arquitetura e Urbanismo da USP].

[SABESP] Companhia de Saneamento Básico do Estado de São Paulo. Sistema Cantareira. São Paulo: Governo do Estado de São Paulo - Secretaria de Recursos Hídricos Saneamento e Obras; sd.

[SABESP] Companhia de Saneamento Básico do Estado de São Paulo. Lagoas de Estabilização de Mairiporã. São Paulo; 1974. [relatório técnico].

[SABESP] Companhia de Saneamento Básico do Estado de São Paulo. Operação da ETA Guaraú. São Paulo: SABESP; 1982.

[SABESP] Companhia de Saneamento Básico do Estado de São Paulo. Data oper. São Paulo: Governo do Estado de São Paulo - Secretaria de Energia e Saneamento; 1989.

[SABESP] Companhia de Saneamento Básico do Estado de São Paulo: banco de dados de qualidade das águas do Sistema Cantareira. São Paulo; 1999. [Banco de dados eletrônico fornecido pela Divisão de Gestão da Qualidade da Produção - APQG]

São Paulo (Estado). Lei n. 997, de 31 de maio de 1976. Dispõe sobre o controle da poluição do meio ambiente. Legislação Estadual - Controle de Poluição Ambiental, São Paulo, 1998. p.18.

São Paulo (Estado). Decreto n. 8.468, de 8 de setembro de 1976. Aprova o regulamento da Lei n. 997 de 31 de maio de 1976, que dispõe sobre a prevenção e controle da poluição do meio ambiente. Legislação Estadual - Controle de Poluição Ambiental, São Paulo, 1998. p.119.

São Paulo (Estado). Lei n. 1.172 de 17 de novembro de 1976. Delimita as áreas de proteção relativas aos mananciais, cursos e reservatórios de água, a que se refere o artigo 2 da Lei n. 898 de 18 de dezembro de 1975, estabelece normas de restrição de uso do solo em tais áreas e dá providências correlatas. Legislação - Regiões Metropolitanas, Proteção dos mananciais, Zoneamento Industrial, São Paulo, dez de 1995. p. II006.

São Paulo (Estado). Núcleo Engordador "Museu da Água". São Paulo: Secretaria do Meio Ambiente; 1993.

São Paulo (Estado). Lei n. 9.866 de 28 de novembro de 1997. Dispõe sobre diretrizes e normas para a proteção e recuperação das bacias hidrográficas dos mananciais de interesse 
regional do Estado de São Paulo, e dá outras providências. LEX - Coletânea de Legislação e Jurisprudência. São Paulo, segundo semestre de 1997. p.1373.

São Paulo (Estado). Gestão das Águas: 6 anos de percurso. Secretaria do Meio Ambiente; 1997. 2v.

São Paulo (Estado). Lei Estadual No 9.866/97 - uma nova política de mananciais. São Paulo: Secretaria de Estado do Meio Ambiente; 1997.

São Paulo (Estado). Entre serras e águas. São Paulo: Governo do Estado de São Paulo; 1998.

Tisdell CA. Environmental economics: policies for environmental management and sustainable development. Great Britain: Cambridge University Press; 1992.

Tominaga MY, Midio AF. Exposição humana a trihalometanos presentes em água tratada. Rev. Saúde Pública. 1999; 33: 413-21.

Vasconcelos VM. Cyanobacterial toxins in Portugal effects on aquatic animals and risk for human health. Braz Journal of Med and Biol Research. 1999; 32: 249-54.

Wiendl WG. Prefácio. In: Frontinus SJ. Das águas da cidade de Roma (97 - 104 d.C.). Trad. de WG Wiendl. São Paulo: CETESB; 1983.

Zagatto PA, Aragão MA. Avaliação ecotoxicológica do Reservatório do Guarapiranga, SP, com ênfase ao problema de algas tóxicas e algicidas. São Paulo: CETESB; 1995 [Relatório técnico].

Zagatto PA, Aragão MA, Carvalho MC, Souza RCR. Manual de orientação em casos de florações de algas tóxicas: um problema ambiental e de Saùde Pùblica. São Paulo: CETESB; 1997. 
8. ANEXOS 



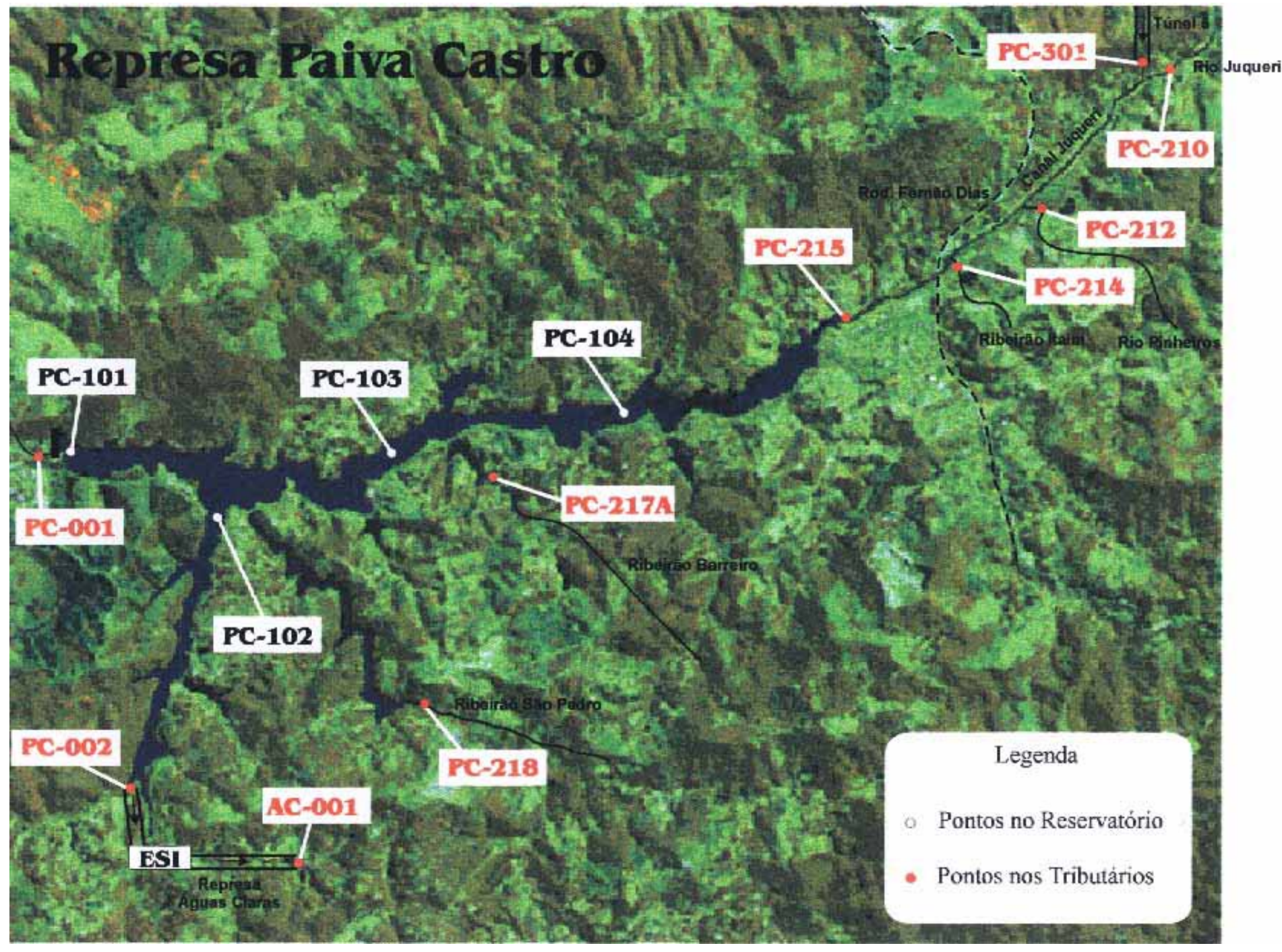

Fonte: SABESP, 1999. 